\title{
执 録
}

\section{1. 化學工學及化學工業用機械}

スプレイ・スクラッパーの钤計 Pease-Antony スクラッバーは高 さ $H$, 直徑 $D$ なる圆塔の下部側面から含塺ガスを內壁に切線に吹 込み旋包上昇させ，その間塔の中央に位置する細長い多孔式の貲霧 器から液滴を放射して接觸除塺する樣式である。液滴の大さは粉塺 の直徑の 200 倍以內がさよい。值徑 $d$ なる液滋はガス容皘 $\left(\pi d^{2} / 4\right)$ (D/2) を掃射して壁に達するから全液量 $W$ 飞依て掃射されるガス 量は

$$
S=\left(\pi d^{2} D / 8\right)\left(6 W / \pi d^{3}\right)=3 D W / 4 d
$$

除塺育は液量加多い程大で，ガスの總量を $G$ とすると

$$
\text { 除塺戠 }=1-e^{-3 D W / 4 d G}
$$

茹に $e$ は自然数數の底である。ガスの吹込速度を $V$, 吹込管の面 皘を $A$ とすると, 液滴作用する遠心力は

$$
X=V^{2} / g D=G^{2} / g D A^{2}
$$

塔內の症力低下 $P$ は $V^{2} / 2 g$ 比例するから

$$
H \infty G \mu / P d D g \infty G \mu / V^{2} g D
$$

茲に $\mu$ は液の粘度。要求されるガスの純度から除塺卒が決るか ら(2) か.ら $D W$ が得られ，(4) の $V, D, H$ の關保依て依灣的 なスクラッバーを設計することが出來る。(R. V. Kleinschmidt, Chem. Met. Eng., 1939, 46, 487)

(楫取松若) (藤 田)

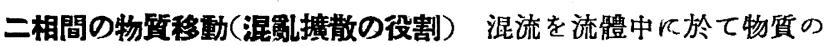
移動郎ち搌數が 行はれる事は 化學工學上種々の操作に於て見られ る。層流をなす流體內の分子墴散に比して混流内の撗散は速度々大

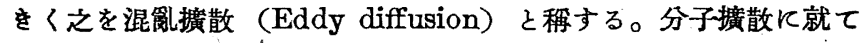

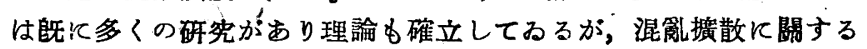
文㗔は少い。

著者の 1 人は最に混流をなす空氣流中に於る $\mathrm{CO}_{2}$ 及 $\mathrm{H}_{2}$ の愦 散に就て報告しえが, 之に依れば搌散速度は漲度勾配に比例し, 其 比例恒數を“混亂摭散率”之名付け, 之はガスの性質に無關保なも のである事を知つた。併し其研究は導管內の中央部の氡流中に於る

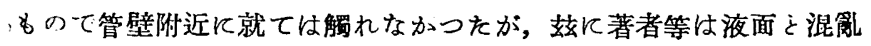
坒氣流間の總括物質移動に就ての結界を報告した。赛驗は断面矩形 の垂直ダクトに於て一側面に水を, 他側面飞 $\mathrm{CaCl}_{2}$ の溶液を上方 から壁に沿って流し，下方から煠氣を上方に吹込み，一㑡の水を蒸 發させて混柕氣流中を擴散し, 他側の $\mathrm{CaCl}_{2}$ の濃溶液に吸收させ る。ダクトの斷面に於る各位置の水蒸氣の分厣を測定して擴散率 計算した。郎ち $E=-\frac{N_{A} R_{G} T}{\left(d p_{w} / d y\right)}$ 於て $E$ は控散來 $\left(\mathrm{cm}^{2} / \mathrm{sec}\right)$, $N_{A}$ は溶質ガスの移動速度 $\left(\mathrm{gmol} / \mathrm{sec}^{2} \mathrm{~cm}^{2}\right) ， R_{G}$ はガス恒數 (cc.m $\left.\mathrm{mHg} / \mathrm{gmol} .{ }^{\circ} \mathrm{K}\right), T$ は絕對溫度 $\left({ }^{\circ} \mathrm{K}\right), p_{w}$ は筀氣中心水蒸氣分厥 $(\mathrm{mm} \mathrm{Hg}), y$ は壁よりの距離 $(\mathrm{cm})$ 。がスとして 空氣の外に He,

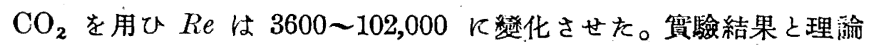
式とを綜合すると工學的には上式の $E$ は次式に依て求め得る事を 知つた。郎ち $E=0.08 U_{0} a_{0} \sqrt{f} て ゙, U_{0}$ はガスの本均速度 $(\mathrm{cm} /$ sec),$a_{0}$ はダクトの中心から壁をでの距離( $(\mathrm{cm}), f$ は湿流飞於る普

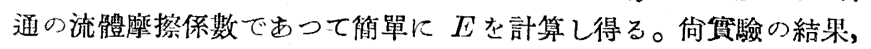
總括擴散抵抗の 28 - 57\% 法流體本體にあり $21 \sim 36 \%$ が各液境膜 に点る事を知つた。(T. K. Sherwood and B. B. Woertz, Ind. Eng. Chem., 1939, 31, 1034)

(藤田重文)
プロパンーイソブチレン系の军液平衡 精油裝置の設計に於ては, 2 種の共存する炭化水素の溫度, 厭力, 氣液兩相の粗成間の關保を 知る事は極めて必要である。又單蒸溜, 吸收を行ふ荘置のみなら ず, 少くとも蒸發, 凝縮が起る樣な傳熱; 流動裝置の設計にも氣液 兩相の本衡關係はすべて設計計算の基礎となる。晌又今日の如く高 通技衔の進步々共に之等の正確なる關保を高厭下に於て知る事も必 要となつた。著者等は高厣に於る相の本衡關係を簡單に湘定する佶 置に就て述へ，プロパンーイソブチレンの蒸氣壓を 臨界點に達する 迄求め, 同時水雨者混合物の $\mathrm{P}-\mathrm{T}-\mathrm{x}-\mathrm{y}$ 關保を求めた。此嘪聽結果 は Lewis の式に依て計算した值之け可成異り，特に笱界點附近 て於ては其差著しく，實驗值を信ずへき事を述へた。(H.W、 Scheeline and E. R. Gilliland, Ind. Eng. Chem., 1939, 31, 1050)

(藤田重交)

濾過助別の作用 同著者の前報 (Ind. Eng. Chem., 1938, 30, 1163）の續報と見るでをすので，10ー2 ミクロンの石英枌末ょり成

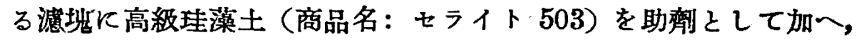
滤過實驗を行つて透過率及氣孔率索測定した。而して助劑を加へた

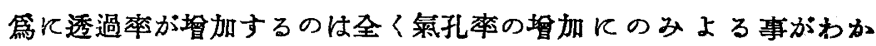
つた。助牒の添加割合を變化させた所によると之依る滤過抵抗 (郎ち透過率)，の變化は前報に於る可鏥性滤過に珪深土を加一を場

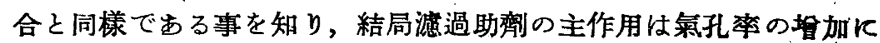
ある事を知つた。依て助劑の有すべ必要條件は夫が高氣孔本を有 する事であり，吸着力，凝固力等を重视して氣孔率を憬性にして はならぬ。(P. C. Carman, Ind. Eng. Chem., 1939, 31, 1047)

(藤田重交)

波滴によるガス吸收 $\mathrm{NH}_{3}, \mathrm{SO}_{2}, \mathrm{H}_{2} \mathrm{~S}, \mathrm{HCl}, \mathrm{CO}_{2}$ 等のガスを 夫及適當な液滴に吸收させてガス境膜の吸收保數 $k g$ を澌定した。 ガスと液滴の相對速度，之び夜滴の大ささを禁化させて其影謷をし らへた。既に著者の 1 人とKleinschmidt は可溶性ガスの液湤

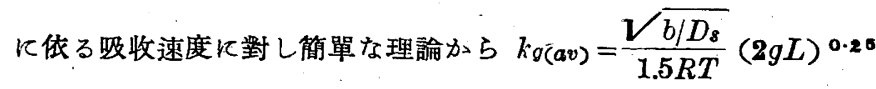
なる式を提出したが，茹に著者等の得を實驗結果を此式に依る計算 值と比較して見るに HCl ガスの $\mathrm{NaOH}$ 溶液澅による吸收を除い

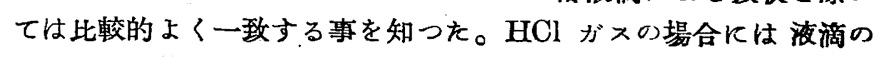

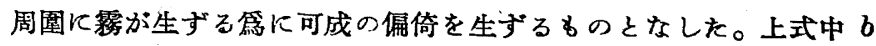
はガスの擴散率， $D_{\boldsymbol{s}}$ は液滴 (球) の直徑，I は液涚の落下距離， $g, R, T$ は夫々重力加速度，ガス恒數，絕對溫度を示す。侣理論

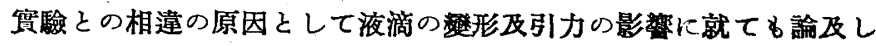
た。又此研究に關聯してノッ゙ルから出る液滴の大さの分布に開する データを基礎とし，简單な向流式スクラッバーの吸收保數の計算が

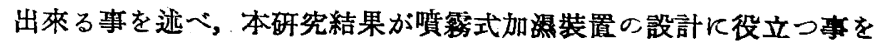
說明した。(H. F. Johnstone and G. C. Williams, Ind. Eng. Chem., 1939, 31, 993) (藤田重文)

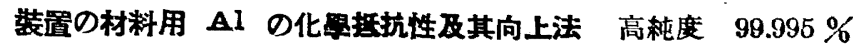

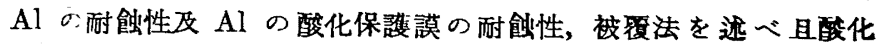
膜の製法に依る差異を示した。更に Al 使用の利點, 腐凔劑の腐

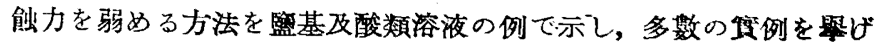
て Al の酸化膜を被覆せる材料の耐刢性を述べた。(Lichtenberg, Chem. App., 26, 217)

(赤嫩亮) (.t. 田)

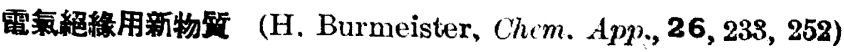

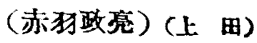




\section{2. 實驗法及實驗裝置}

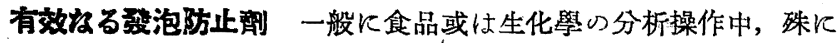
室溫にて水中で粘性大なる物質に通氣操作（aeration）行ふ場合 に，發泡の現象に依て困難を覺へる事がある。パラフィン油，カプ リルアルコール, フェニルェーテネ等は斯る際り 良好なる消泡劑で あるが，操作中にネスラー試薬々作用して不利なる場合がある。才

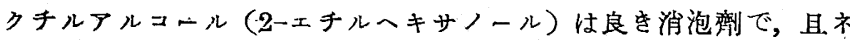
スラー試藥に何等の影警も無いが、然し 2 時間後には急速に 10 15 分間にて逸散すると言子充分ならざる點がある。オクチルアル コールに種々の物質を混ぜ，其蒸氣迭を低下させ且發泡防止性を增 す事を試みたが，次記の混合物は其目的に成功した。

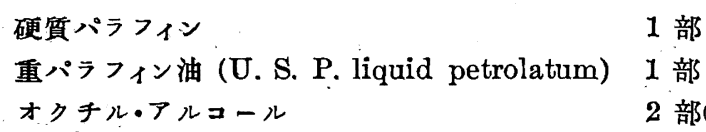

著者等は之を約 $60 \mathrm{cc}$ の試料に約 $\mathrm{lg}$ 使用し，遊離アンモ=アの 㵋定に用ひて非常に良好なる.結果を得た。(Phileas A. Racicot and Carl S. Ferguson, Ind; Eng. Chem. Anal. Ed., 1939, 11, 380)

(近藤三千雄) (神 原)

\section{3. 理 論 化 學}

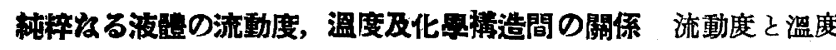 その關保を表はす炏の方程式は

$$
\boldsymbol{\varphi} / T=a+b T+\cdots \cdots
$$

$\boldsymbol{\varphi}$ : 流動度 RHES (reciprocal poise) $T$ : 絕對溫度

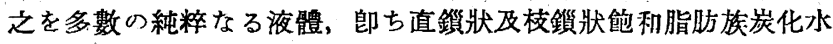
素, 不飽和炭化水素, 芳香族炭化水素, 真化及沃化アルキル, ェー テル,アルデヒド, ケトン, 無水物, エステル, チオアルコール （第 1 及第 2)，硫化アルキル及無機性液體(元素及液化ガスを含む) に就て當てはめたとこる, 流動度一溫度間の關保を高次の項を入れ ないです非常に正確に表はすととを知つた。方程式 (1) に於る常數 $a$ は化合物の屬する同族體系の函數であり，bは忙同族體系の 化合物の分子量の函數である。依て同族體系にのみ關保し各々化合 物には無關保の常數を含む方程式が得られる。郎ち

$$
\varphi / T=A s+\alpha T 10^{\left(\beta / M-\gamma / M^{2}\right)}
$$

$M$ : 分子量, $\alpha, \beta$ 及 $\gamma$ : 常數

系の常數 As 脂肪族の 6 心系, 郎亏 $\mathrm{n}$-炭化水素, iso-炭化水

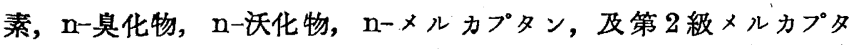
ンに就て各化合物の常數 $a$ を本均して求めた。 $b$ の值は上の系の 常數から計算して求め, 最後に $\alpha, \beta$ 及 $\gamma$ を計算により求めた。 之等の $A_{S}, \alpha, \beta, \gamma$ 各常數の値より式 (2) Kょり硫動度を計算し, 湘定值と比較するとよく一致する。式（1）及（2）を用ひる場合， 水酸基を含む化合物は異常を示す。其代表的なものは脂肪族酸， ルコール，及水である。この中脂肪族酸及水は式 (1) 飞比校的よく 從ふが,アルコールは可成異常を呈する。

以上の如く流動度と溫度との上記の關保式はアルコール以外の多 數の液體に對し非常飞正確である。倘此式は同族體系の連縝せる各 化合物の粘度一溫度函数の間の一定の關保をも示す。從て式 (2) の 4 個の常數を用ひて，會合しない化合物系の各々の粘度を如何なる 溫度に於るものでも計算により求的るてと加出來る。式 (1) は溶液 にも純粹な液體々同樣に正確に適用されることも制明した。著者は 倚此方面に就て研㭝中である。(F. C. Bingham \& S. D. Stookey, J. Amer. Chem. Soc., 1939, 61, 1625)

(酶井千秋) (勝 野)

$25^{\circ}$ の溫度標蕉としてのヂフェニルメタン $25^{\circ}$ 附近の 溫度の標 染としてヂフェニルメタンの融點を測定した。ヂフェニルメタン

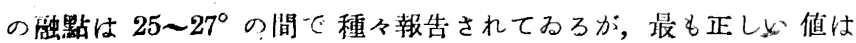

Smith 及 Andrews ( $J$. Amer. Chem. Soc., 1931, 53, 3644) の報 告せる $25.15^{\circ}$ であらら。著者は再結晶を繰返して精製せるヂフェ ニルメタンの融點を熱電對を用ひて湘定した結果 $25.09 \pm 0.01^{\circ}$ な る值を得を。

デフェニルメタンは時間々共に徐々に分解を起し其融點が降下す る。之は光が其分解を 促進する䉆で，褐色濹に眝藏すれば 4 週間 後に約 $0.002^{\circ}$ の降下゙があるに對し, 無色の塯では 4 㛠間後に約 $0.1^{\circ}$ の降下があつた。分解して融點の降下せるものは再結昆を繰 返して精製すれば元の融點に復する。(Thomas De Vries \& Henry A. Strow, $J$. Amer. Chem. Soc., 1939, 61, 1796)

(鹋井千秋) (勝 野)

モノ及ポリスチロールの撚焼熱 モノスチロールを $180^{\circ} \mathrm{C}$ で 6 時間 加熱重合して得をるのをポリスチロールA とし, 更に之を分 別沈濒して均一なものにしたものをポリスチロールBとして粘度 测定より之等の重合度が異なる事を示儿且分子然燒熱も異なる事を 示した。郎ちモノスチロールにては $1045.4 \mathrm{kcal}$, ポリスチロールA にては $1034.8 \mathrm{kcal}$, ポリスチロール B にては $1031.6 \mathrm{kcal}$ であ る。重合に際し $-\mathbf{C}=\mathrm{C}-$ が $-\mathrm{C}-\mathrm{C}$ 一をなる時熱化學理論によれ ばスチロール分子につを $26 \mathrm{kcal}$ のエネルギー損失となるわけ だが實際は 10〜14 kcal である。郎ちポリスチロールに於ては一 C一C一の結合力は正常の分子の時よりもより小さい事が制つた。 W. v. Luschinsky, Z. phys. Chem., (A), 1938, 182, 384)

（稻坦英吉）

\section{4. 無 機 化 學}

熔融アルカリ監化物之其監化ナトリウムとの二成分混合物の蒸氣 㗨 $\mathrm{LiCl}, \mathrm{NaCl}, \mathrm{KCl}, \mathrm{RbCl}$ 及 $\mathrm{CsCl}$ の蒸氣原を $860 \sim 990^{\circ} \mathrm{C}$ の 溫度範圍に於て流動方法飞依て測定し其測定值と在來の值とを比较 檢討し諭述した。又其の $\log p-1 / T$ 圆より同溫度笔圍に於る蒸發 熱を計算し從來の値と比較した結果，著者等の測定値は堀場及馬場 兩氏の最近の湘定值とよく二致するを見た。次に同溫度範圍に於る LiCl-NaCl KCl-NaCl, RbCl-NaCl, 及 CsCl-NaCl 2 成分混 合物に於る各 25, $50,70 \mathrm{~mol} \%$ の濃度の分避を同じく流動法に依 て測定しえ。反應後殘留監の租成は其重さとそれを水に溶解してク 口儿濃度を測定して定めた。著者等は更に是等混合物の分遙を

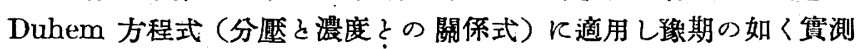
值に好くは一致せぬを見た。郎ち是等の蒸氣に就て理想氣態の法測

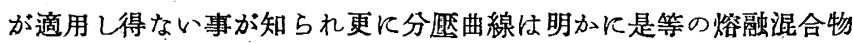
が理想溶液でなしk化學的に類似の物質から成る事を示した。(W. Kangro \& H. W. Wieking, Z.phys. Chem. A, 1939, 183, 199) (村井金城) (阿 部)

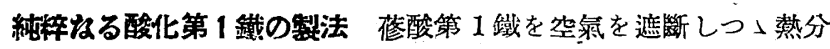

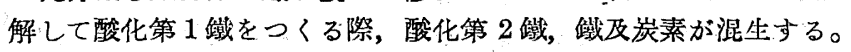
苳酸第 1 轱熱分解の際には

$$
\mathrm{Fe}\left\langle\underset{\mathrm{O}-\mathrm{CO}}{\mathrm{O}-\mathrm{CO}} \rightarrow \mathrm{FeO}+\mathrm{CO}+\mathrm{CO}_{2}\right.
$$

なる主反憵の外飞 (1) $4 \mathrm{FeO} \rightarrow \mathrm{Fe}_{3} \mathrm{O}_{4}+\mathrm{Fe}$, (2) $\mathrm{FeO}+\mathrm{CO} \rightarrow \mathrm{Fe}+$ $\mathrm{CO}_{2}$ ，(3) $2 \mathrm{CO} \rightarrow \mathrm{CO}_{2}+\mathrm{C}$ なる副反應の件ふてこをガス分析及反應 生成物の分析より知り，此副反㤰を起さしめずに純酸化籍 1 驖を製 造するには $900^{\circ} \mathrm{C}$ にて熱分解を行ひ，分解生成茂スを極めて速に 吸引し去り，分解生成物を常溫去で急冾す九ばよい。かくの如き方 法に依て $\mathrm{FeO} 99.98 \%, \mathrm{C} 0.01_{5} \%$ なるものを得た。(P. L. Gunther, Angew. Chem., 1939, 52, 510)

(野田榴吉)

イオン半徑と週期律 Paulingの1俔イオン牛徑なる概念を使つ

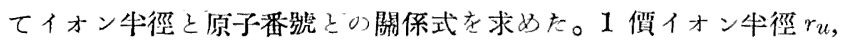
イオン僄 $z$ なろオンの粗の半徑 $r z$, Born の Absto Bungsexponentを $n$ よすれば 


$$
r_{z}=r u \cdot z^{-2(s(n-1)}
$$

でむる。

Pauling が波動力學的計算により理論的に求めた1㑑イオン牛徑 の逆數 $1 / r_{u}$ を各元素に就て計算し相隣る元素間の差を求めてみる と週期表の同一列に就ては此差が一定であるととが知れた。郎ち

$$
\frac{\left(\frac{1}{r_{u}}\right)_{N}-\left(\frac{1}{r_{u}}\right)_{N^{\prime}}}{N-N^{\prime}}=k
$$

一方 $n$ と $k$ との間には

$$
1 / k=2(n-4)
$$

なる關係が知られた故 (2) 式に入れ整理して

$$
\left(\frac{1}{r_{u}}\right)_{N}-\frac{N}{2(n-4)}=\left(\frac{1}{r_{u}}\right)_{N^{\prime}}-\frac{N^{\prime}}{2(n-4)}
$$

をらる。

同一貴ガス型イオン郎ち同一列のものに就ては $n$ は同一である から（1）飞（4）京上り原子番號圭知つてイオン牛徑を求め得る。 各列元素に就て實驗的に次式を得衣。

$$
\begin{aligned}
& \mathrm{He} \text { 型 } n=\underset{(5)}{4.9}(\mathrm{H} \rightarrow \mathrm{F}) \quad\left(\frac{1}{r_{u}}\right)_{N}=\frac{N}{2(n-4)} \\
& \mathrm{Ne} \text { 型 } \underset{(7)}{n=7.1}(\mathrm{C} \rightarrow \mathrm{Cl}) \quad \text { " }=\frac{N-6}{2(n-4)}+0.26 \\
& \text { A 型 } \underset{(9)}{n=9.0}(\mathrm{Si} \rightarrow \mathrm{Fe}) \quad " \quad=\frac{N-14}{2(n-4)}+0.26 \text { ， } \\
& (\mathrm{Cu} \rightarrow \mathrm{Br}) "=\frac{N-14}{2(n-4)}+0.26-0.715 \\
& \mathrm{Kr} \text { 型 } \underset{(10)}{n=10.1}(\mathrm{Ge} \rightarrow \mathrm{Ru}) \prime=\frac{N-32}{2(n-4)}+0.26 \\
& (\mathrm{Ag} \rightarrow \mathrm{J}) "=\frac{N-32}{2(n-4)}+0.26-0.715 \\
& \mathrm{X} \text { 型 } n=\underset{(12)}{11.6}(\mathrm{Sn} \rightarrow \mathrm{Ce}) \text { " }=\frac{N-50}{2(n-4)}+0.26 \\
& (\mathrm{Cp} \rightarrow \mathrm{Os}) \prime=\frac{N-50}{2(n-4)}+0.26-0.715 \\
& (\mathrm{Au} \rightarrow \underset{-85)}{\prime})=\frac{N-50}{2(n-4)}+026-2 \times 0.715 \\
& \mathrm{Em} \text { 型 } n=12.8(\mathrm{~Pb} \rightarrow \mathrm{U}) "=\frac{N-82}{2(n-4)}+026
\end{aligned}
$$

此式よりの計算値は Pauling の理論的値, Goldschmidt の賽驗 的値さよく一致する。份 $n$ の值中括弧內は Pauling の與へた值で ある。(K. Kordes, Z. physik. Chem. B, 1939, 43, 213)

\section{（野田稻吉）}

人エマグネタイトの構造 $\mathrm{FeCl}_{2}$ そ $\mathrm{FeCl}_{3}$ の混合溶液よりアン

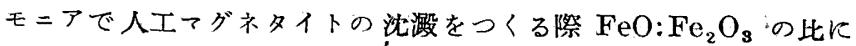
$\mathrm{FeO}$ を含むものは得難い。沈潵中の第1瀻は $\mathrm{NH}_{4} \mathrm{Cl}$ を含むアン モニア水で沈澱中ょり洗ひ去られるととが知れた。 $\mathrm{Fe}_{3} \mathrm{O}_{4} \cdot x \mathrm{H}_{2} \mathrm{O}$ に必要な量より $\mathrm{Fe}(\mathrm{OH})_{2}$ として $10 \%$ 過剩な $\mathrm{FeCl}_{2}$ と $\mathrm{FeCl}_{3}$ の混合溶液より沈澱したものは $\mathrm{FeO} 26.4 \%$ であつた。混合溶液 の調製方法で得た沈溊の酸化速度は異るが，空氣にふれると $\mathrm{FeO}$ 量を減ずる。沈澱中の $\mathrm{FeO} \%$ が天然マグネタイトの $\mathrm{FeO} \%$ と異 るのは朁に生成した沈澱 $\mathrm{Fe}_{3} \mathrm{O}_{4} \cdot x \mathrm{H}_{2} \mathrm{O}$ が酸化するのでなく，沈涮 を生ずる際母液中の $\mathrm{Fe}^{++}$が缺乏すると沈澱中の $\mathrm{Fe}^{++}$が液中 に溶解してゅく衣めである。かく、グネタイト格子中ょり $\mathrm{Fe}^{++}$ が沙ひ去られるといふのは人工マグネタイトの構造に由來する。天 然マグネタイトの結晶格子の單細胞は $24 \mathrm{Fe}$ イオンと $32 \mathrm{O}$ イオン を含み，Oイオンが略々立方最密充垣型をとる。陽イオンは其聞隐 に入つてるる。 $\mathrm{Fe}^{+++}$の牛は 4 面體間腺に, 他の牛々 $\mathrm{Fe}^{++}$とは 8 面體間隙に志る。郎方 $\left(8 \mathrm{Fe}^{+++} 8 \mathrm{Fe}^{+++} 8 \mathrm{Fe}^{++} 32 \mathrm{O}^{--}\right)$の如 さ構造で声る。人エマグネタイトを酸化して得られる $\gamma-\mathrm{Fe}_{2} \mathrm{O}_{3}$ は
マグネタイトと同樣な酸素格子をつくる。其構造は $\left(8 \mathrm{Fe}^{+++} 13 \frac{1}{3}\right.$ $\left.\mathrm{Fe}^{+++} 32 \mathrm{O}^{-}-\right)$郎ち陽イオンのあるべき格子點に 空所を有する。 人エマグネタイトも $\gamma-\mathrm{Fe}_{2} \mathrm{O}_{3}$ と同樣陽イオン格子は不完全と考一 られる, 此場合には $\mathrm{FeO}$ の少いのは $\mathrm{Fe}^{++}$が格子ょり取去られ たためである。結晶格子の安定なるためには陰イオン格子が完全で なければならない。OH-は $\mathrm{O}^{--}$子略其半徑が同じく $\mathrm{O}^{-}$一の代 りに格子に置換へられらるから $\mathrm{Fe}^{++}$の缺けた分に相當する丈は O-一の代りに OH一 が入らなければイオン貨の均衡がれない

。郎ち人工マグネタイトより $\mathrm{Fe}^{++}$が取去られる場合

$\left[2 \mathrm{Fe}^{++}+2 \mathrm{O}^{--}\right]+2 \mathrm{H}_{2} \mathrm{O}=\left[\mathrm{Fe}^{++}+2 \mathrm{OH}-\right]+\mathrm{Fe}(\mathrm{OH})_{2}$ (液底體中) (

の如く $\mathrm{O}^{--}$分 $\mathrm{OH}^{-}$で置換へられる，故に置換された $0^{--}$に 相當する $\mathrm{Fe}^{++}$の $\frac{1}{2}$ が溶液中に入るととになる。期樣にしてて人 エマグネサイト中K $\gamma-\mathrm{Fe}_{2} \mathrm{O}_{3}$ 字陽イオン格子點空所の $1 / 2$ が生じ たとするならば

$$
\left(8 \mathrm{Fe}^{+++} 8 \mathrm{Fe}^{+++} 6 \frac{2}{3} \mathrm{Fe}^{++} 29 \frac{1}{3} \mathrm{O}^{--} 2 \frac{2}{3} \mathrm{OH}^{-}\right) .
$$

なる格子構造を有するであらら。此搆造に相當する $\mathrm{FeO}$ 量は無水 酸化物に對して $27.27 \%$, 水は $14 \%$ となり,之は賽驗的飞得られ。 るるのとよく一致する。以上の如搆造を與へるてとにより人エ、 グネタイトの種々なる性質がよく說明される。 (K. Starke, $Z$. physik. Chem. B, 1939, 42, 159)

(野田稻吉)

\section{5. 有 機 化 學}

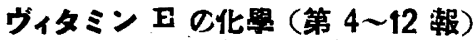

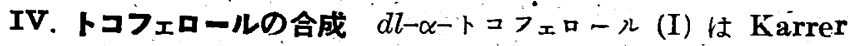
等 (Helv. Chim. Acta, 1938, 21, 520) とょりトリメヂルヒドロキ

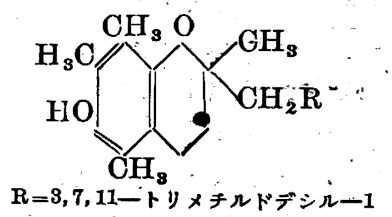

(I)

\section{ノンと臭化フィチルから $\mathrm{ZnCl}_{2}$ を 縮合劑として初めて合成され゙た が，著者等は溶媒も觸媒も用ひず， 且吸着精製を行はずに純物質を好 收量で得た。}

Karrer の惯驗 (ibid., 1938,

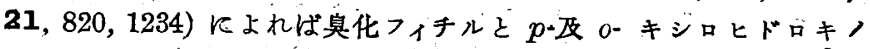

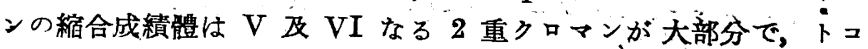
フェロール (II 及 III) は少い。

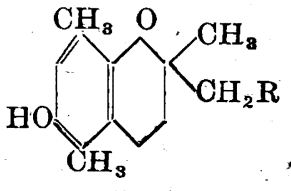

(II)<smiles>[R2]CC1(C)CCC(O)C(C)=C1C(C)C</smiles><smiles>[AlH2]</smiles>

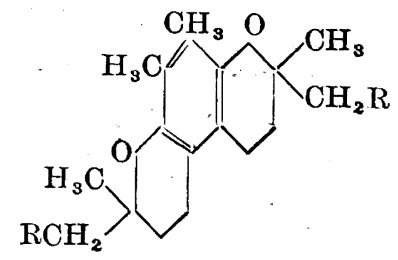

(VI)<smiles>[R2]CC1(C)CCC2C(O)CCCC21O</smiles>

(III)

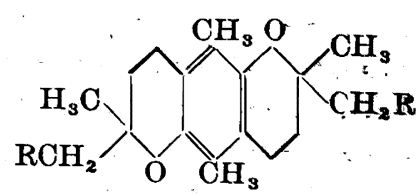

(V)

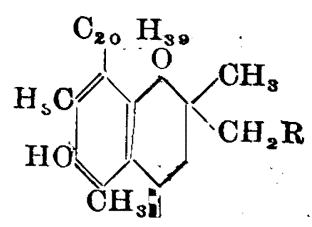

(VII) m-キシロヒドロキノンでは 2 重クロマンを與いる事は出來ない 
が、トコフェロール（IV) 及其フィチル誘導體（VII）を生ずるで あら5。 $p$-及 $m$-キシロヒドロキノンに就ての著者等の實噞の結果, $p$-キシロヒドロキノンと具化つィチルの縮合成績體は沸點 145〜 $150^{\circ}$ で，分析の結果 (II) 及 (V) の混合物なる事がわかつた。 $m$ キシロヒドロキフンからの成績體は $\alpha$ トコフェロールよりも沸點が 低く，恐らく(IV) で壳らら。此物質は生物學的活性である。(I. I. Smith, H. E. Ungnade, J. Org. Chem., 1939, 4, 298)

（䉀力）（桂樹日出雄）

จ. フェノール及ヒトロキノンの直接アリル化 Claisen は活性な 八ロゲン化アリルはフェノールと發熱的に反應する事を發見し，此 反應を用ひて㨁接の C-アリル化を行つた。此反應はフェノールと 八ロゲン化物の雨方の活性K閵係し，ヒドロキノン及其メチルェー テルでは反鷹せぬとした。著者等はポリアルキルフェノール及ヒド ロキノンに關して赛驗した。臭化アリルとしてはナリルー, $\boldsymbol{\gamma}, \boldsymbol{\gamma}$-ヂメ

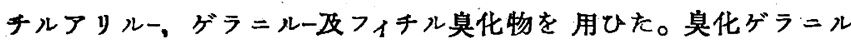
は最も反應性に富むが副反應を起してテルペン樣物質を與へる。他 の 3 種の臭化物は封管中で $100 \sim 150^{\circ}$ K加熱すると總てヒドロキ ノンと反應する。觸媒は $\mathrm{ZnCl}_{2}$ が良いが收量に影帮はない。 $\gamma, \gamma$ ヂ置換アリルハロゲン化物はクロマンを與へるが，臭化アリル自身 の時はクマランを與へる。郎ちトリメチルヒドロキノン (I) と臭化 アリルはクマラン (II) を, (I) と $\gamma, \gamma$ ヂメチルアリル臭化物はク ロマン (III) を與へる。<smiles>CC(O)C(O)O</smiles>

(I)

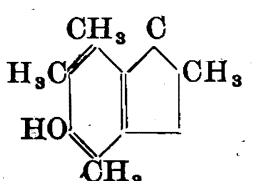

(II)<smiles>CCCC1(C)OC(C)(O)CCC1(C)O</smiles>

(III)
1 個所より多くの反應點を有するヒドロキノン及フェノールと臭 化物との縮合成綪體は複雜でクロマン又はクマラン以外反アリル化 誘導體及それと $\mathrm{HBr}$ の附加化合物を共生する。例人ば 2,3,5-卜 リメチルフェノール (IV) と臭化フリルは V, VI 及 VII を生ず ろであらら。<smiles>CC(C)C(C)O</smiles>

(IV)<smiles>CC1=C(C)C2CCC1C(C)=C2C</smiles>

(V)<smiles>C=CCCCC1(C)CCCCC1CC=C</smiles>

(VI)

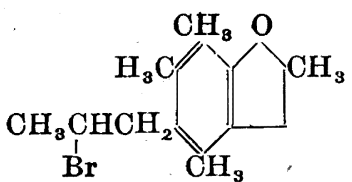

(VII)
(L. I. Smith, H. E. Ungnade, H. H. Hoehn, S. Wawzonek, bid., 1939, 4, 305)

（篗力）(桂樹日出雄）

VI. フェノール及ヒドロキノン ヘ ヂンの附加 Claisen によ ればフェノース類は酸性觡媒の 存在でデェンと縮合しクロマンを生 ずる。

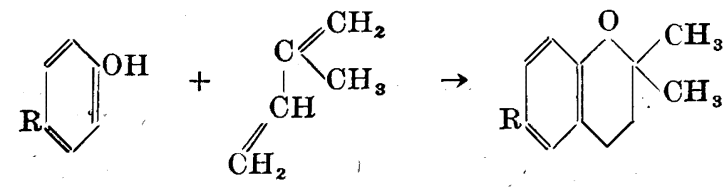

著者等は此反應をポリメチルフェノールとヒドロキノン及其モノ エーテルに啲用してトュフェロールの合成を企てた。反隹條件を楜 賞にすればメチルヒドロキノンヌ其ェーテルはヂェンと縮合するが

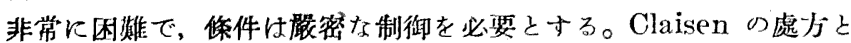

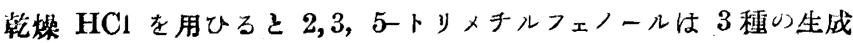

物郎ちクロマン (I)，フェノール (IIa 及 IIb) 及クロマン (III) を 與へる。<smiles>CC1=CC=CC2CC(C)(C)OC12C</smiles>

(I)<smiles>CC(C)(C)CC1CCCCC1(C)O</smiles>

(IIa)<smiles>CC(C)=CCc1ccc(C)cc1</smiles><smiles>CC(C)=CCC1CCC(C)(C)OC1C(C)C</smiles>

ヒドロキノン自身は Claisen の條件ではギェンK對し殆ど不活 性であるが，其のモノメチルェーテルは容易にギメチルブタヂェン と縮合し，2,2,3-トリメチルー6ーメトキシクロマン(IV) を與へる。<smiles>CCc1cccc(C(=O)C(C)(C)C)c1CC</smiles>

(IV) メテルヒドロキノンはヒドロキノ ン自身よりも反應性で,トリメチ ルヒドロキノンはイソプレンと縮 合して2,2,5,7,8-ペンタメチルー 6ーヒドロキシクロマン (V)を好收 量で與へる。

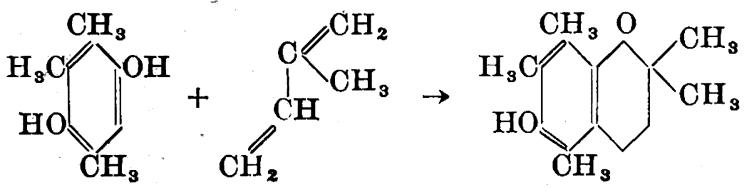

(V)

トリメチルヒドロキノンはブタヂェンと縮合して少量の $d l-\alpha-$ トコフェロールを生ずる。2,5-デメチルヒドロキノンとイソプレン の反應は唯粘䅕な油を與へるのみである。(L. I. Snith, H. E. Ungnade, H. H. Hoehn, S. Wawzonck, ibid., 1939, 4, 311)

(笹力) (桂樹日出雄)

VII. メチルフェノール類からキノンの生成 トコフェロールの合 成に關聯してメチルキノンを多量に得る事を必要とし，其合成を企 てた。プソイドクメンから直接舁素化により，5-及3-誘導體を得る。 5ーブロモプンイドクメンは Smith 及 Moyle (J.Amer. Chem. Soc., 1936, 58, 1) 飞上れば容易に 3-ブロモ誘導體飞變化する。後 者はアルカリと $\mathrm{Cu}$ でプソイドクメノール-3 (I) を與へる。 I を $\mathrm{K}_{2} \mathrm{Cr}_{2} \mathrm{O}_{7}$ で酸化すると $50 \%$ の收量でトリメチルキノンを生ず る。プゾイドクメノールー6 (II) は酸化により全然キノンを與へな い。<smiles>CC(C)O</smiles>

(I)<smiles>CC(C)C(O)C(C)C</smiles>

(II)<smiles>CC(C)NC(C)O</smiles>

(III)
フェノールをキノンに縎いるのに, 先づヂアゾ化合物とカップリン グさせる友法を考へ店。ヂアゾ化スルファニル酸を强アルカリ性溶 液でフェノールとカップリングさせると $p$ 一ヒドロキシーアジ化合物 が得られ, 之は $\mathrm{SnCl}_{2}$ そ $\mathrm{HCl}$ で $p$ アミアフェノール (III) を生 ずる。(III) は遊離せず過剩の $\mathrm{FeCl}_{3}$ を加一蒸氣蒸溜を行子と副 出物からキノンが得られ，其收量はフェノール(II) K對し $90 \%$ 以 
上である。同漛に 3,5-ヂメチルフェノールは 74\% で $m$-キシロキ ノンを，2,5-ヂメチルフェノールは $55 \%$ で $p$-キシロキノンを, ヂ ウレノールは $60 \%$ でデウロキノンを與へる。0-及 ヴークレンール からは痕跡のトルオキノンを得た。

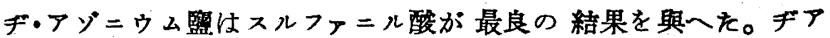
ゾ化アニリンはフェノールそカップリングするが, 此アゾ化合物の 還元で生ずるアニリンはキノンと反應する故不可である。(L. I. Smith, J. W. Opie, S. Wawzonek, W. W. Prichard, ibid., 1939, 4, 318)

（䈎 力）(桂樹日出雄)

VII. ポリメチルヒドロキノン類及其誘導顝のクロロメチル化 : ヒドロキノンエーテルの開翌 $p$-ヒドロキシークロマン及ークマラン の合成はとドロキノンを出發物とし，之に適當の側鑟を導入し，最 後に䦥環する。然し 顀を 1 段階で導入する事结不可能で，漸次に作り上げねばならぬ。 此場合 Grignard 反應, アルカリ性アルキル化及加水分解等を必 要とする。然しポリメチルとドロキノンはアルカリに不安定で, 且

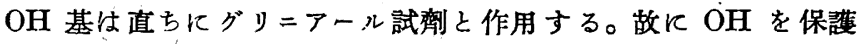
し, 同時飞最後に容易に分解されるゅらな保護基が必要である。 先ブトリメチルヒドロキノンのデメチルエーテル (I) から出發し た。之は Smith 等の方法 (J.Amer. Chem. Soc., 1936, 58, 634) で クロロメチル誘導體 (II) 飞戀化する。(II)は Naーアセト醋酸エス テルと反應し, 加水分解して定量的にケトン (III) となる。(III) ょり(IV) 合成するのK先ゔ種々の方法で(III)の脫メチル化を行<smiles>COc1ccc(OC)cc1</smiles>

(I)<smiles>COC(O)C1CCOC1C</smiles>

(II)<smiles>[R]C1(C)CCC(O)=C(CC)C1CCC</smiles>

(IV)
つたが何れる不成功であつた。例へば沸騰ベンゾール中で $\mathrm{AlCl}_{3}$

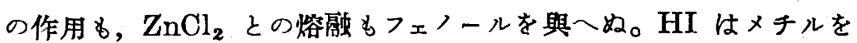
除くが副反應を生じ, 又 $\mathrm{HBr}$ \&不可であつた。

次にアルデヒド (VII) を.出發物とする第に (II) をアセテート (V), カービノール (VI) を粨，酸化して (VII) となした。收量は

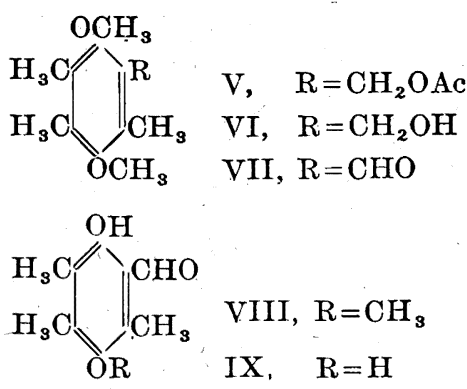

(I) に對し 60〜70\%で ある。(VII) の腃メチ ル化を $\mathrm{AlCl}_{3}$ で行ふ 之常K(VII)(VIII)及 (IX) の混合物を與へ, 其收量は惡い。

$$
\text { メチルェーテルの分 }
$$

解は斯く困難である 故, 他の保護基を研究
した。先ゔェチル基に同樣の實驗をしたが失敗した。ベンジル基は 分解が容易であるが，ベンジルェーテルの生成が困難で，七ドロキ ノンに監化ベンジルを作用するを C-ベンジル誘導體を主生する。 フェニルデアゾメタンも不成功であつた。次にアリルオキシ酸の分

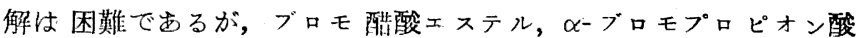
とヒドロキノンの作用を研究した。ヒドロキノンと $1 \mathrm{~mol}$ のブロモ エステルを作用するとモノェーテル $(\mathrm{X})$ ， デェーテル(XI) 及未反 應のヒドロキノンが得られる。(XI) け容易にクマラノン (XII) K なるが脫アルキル化は出來ない。<smiles>CC(=O)OC1CCCCC1O</smiles>

$(\mathbf{X})$

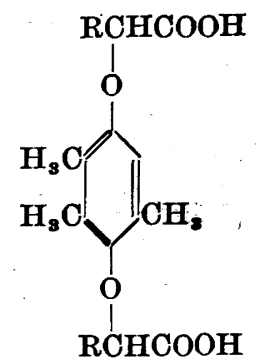

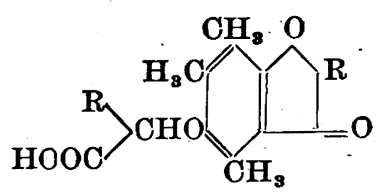

(XII)

最後にエステルを保護基とした。ヒドロキノンは容易にデアセテ ートとなり,之より得られるクロロメチル誘導體をアセト醋酸エス<smiles>CCOC(=O)C(CC1C(C)C(O)CC1C(C)O)OCC</smiles>

テルでアルキル化すると七ドロキノンエステル（XIII）を $40 \%$ 生 ずる。これからケトンを作り，アルコールとなしクロマンを作る 事が出來る。此實驗は後報する。(L. I. Smith, H. E. Ungnade, J. W. Opie, W. W. Prichard, R. B. Carlin, E. W. Kaiser, ibid., 1939, 4, 323)

(笹 力) (桂樹日出雄)

IX. 1ソペンタン單位を含せ長頖ハロゲン化物及ケトンの生成 トコフェロールの合成に關聺して (I) 及 (II) 型のハロダン化物及 (III) 型のケトンが必要である。本報ではか」る化合物の合成を試 みた。ゲラニオール (IV) 及シトロネロール(V) を出發物とした。

$n=1$ 又は 2

$\left(\mathrm{CH}_{3}\right)_{2} \mathrm{CHCH}_{2} \mathrm{CH}_{2}\left[\mathrm{CH}_{2} \mathrm{CH}\left(\mathrm{CH}_{3}\right) \mathrm{CH}_{2} \mathrm{CH}_{2}\right]_{\mathrm{n}} \mathrm{X}$

$\left(\mathrm{CH}_{3}\right)_{2} \mathrm{CHCH}_{2} \mathrm{CH}_{2}\left[\mathrm{CH}_{2} \mathrm{CH}\left(\mathrm{CH}_{3}\right) \mathrm{CH}_{2} \mathrm{CH}_{2}\right]_{n} \mathrm{CH}_{2} \mathrm{X}$ (II)

$\left(\mathrm{CH}_{3}\right)_{2} \mathrm{CHCH}_{2} \mathrm{CH}_{2}$. $\left[\mathrm{CH}_{2} \mathrm{CH}\left(\mathrm{CH}_{3}\right) \mathrm{CH}_{2} \mathrm{CH}_{2}\right]_{n} \mathrm{CH}_{2} \mathrm{COCH}_{3}$ (III)

$\left(\mathrm{CH}_{3}\right)_{2} \mathrm{C}=\mathrm{CHCH}_{2} \mathrm{CH}_{2} \mathrm{C}\left(\mathrm{CH}_{3}\right)=\mathrm{CHCH}_{2} \mathrm{OH}$.

$\left(\mathrm{CH}_{3}\right)_{2} \mathrm{C}=\mathrm{CHCH}_{2} \mathrm{CH}_{2} \mathrm{CH}\left(\mathrm{CH}_{3}\right) \mathrm{CH}_{2} \mathrm{CH}_{2} \mathrm{OH}$

その合成法は次の如し。不飽和アルコールの還元：ゲラニオーメ (IV) は Raney, Ni の 存在で $\mathrm{H}_{2}$ を $100^{\circ}, 2000 \mathrm{lb}$ で吸收する。 $150^{\circ}$ で反應は完結せぬが $200^{\circ}, 25501 \mathrm{~b}$ で完結する。此遗元は 2 階 段で行はれ，アリル性 2 重結合の館和は高溫を必要とする。シトロ ネロールの還元はアリル性 2 重結合を有しないから $125^{\circ}$ で完結す る。アルニールよりハロゲン化物の生成：ハロゲン化物の生成は乾 燥ハロゲン化水素で行ふ。乾燥劑の存在が有利である。パーヒドロ ゲラニル具化物によるアセ卜醋酸ェステルのアルキル化: Fischer (Ann., 1929, 475, 183) の方法では $45 \%$ の收量で生ずる。之を高 溫で加水分解するとケトン $(\mathrm{III}, n=1)$ を $61 \%$ の收量で生ずる。 $\mathrm{C}_{10}$ ハロゲン化物より $\mathrm{C}_{11}$ バロゲン化物の生成: $\mathrm{C}_{10}$ 化合物の顉 を晢加するには先ゔ $\mathrm{RMgX}$ を作り，之をクロロメチルエーテれ と反應せしめ, エーテル (VI) とする。(VI) を(II) にするには 48 $\% \mathrm{HBr}$ では失敗したが, 乾燥 $\mathrm{HBr}$ で $135^{\circ}$ で威功した。

$$
\mathrm{I} \rightarrow \mathrm{RMgX} \stackrel{\mathrm{ClCH}_{2} \mathrm{OCH}_{3}}{\rightarrow} \text {, }
$$$$
\mathrm{RCH}_{2} \mathrm{OCH}_{3}(\mathrm{VI}) \rightarrow \mathrm{RCH}_{2} \mathrm{X}(\mathrm{II}, n=1, \mathrm{X}=\mathrm{Br})
$$

(L. I. Smith, H. E. Ungnade, F. L. Austin, W. W. Prichard, J.W. Opie, ibid., 1939, 4, 335) （䈎 力）(湘樹日出雄）

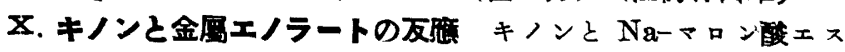
テルからクマラン誘導體が得られて居るが, 著者等はアセトメシす レンの $\mathrm{MgBr}$ レラート(I)を利用して此合成を企てれ。此型の 
エノラートはトリメチルヒドロキノンと容易に反應してケトン (II) を生ずるが，(II）を脱水してクマロン (III) を得る事は出來なかつ t。<smiles>C=C(OC)c1ccccc1Br</smiles>

(I)<smiles>Cc1cccc(O)c1OC(=O)C1C(C)CCC(O)C1C</smiles>

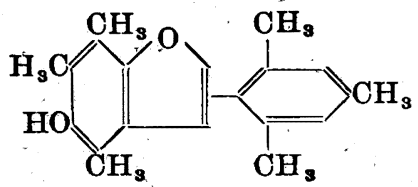

又 $\gamma$ ープロモアセ卜醋酸 (V) は容易に作られるが、てれをエノラ 一ト（VI）飞變へる事は出來ない。從でキンと摍合は出來ない。

$$
\begin{aligned}
& \text { R } \mathbf{R}^{\prime} \\
& \mathrm{CH}_{3} \mathrm{COCCOOC}{ }_{2} \mathrm{H}_{5} \\
& \text { (IV) } \\
& \mathrm{CH}_{2}=\underset{\mathrm{OMgBr}}{\mathrm{R}-\mathrm{CCOOC}} \mathrm{R}_{2}
\end{aligned}
$$

$\mathrm{R} \quad \mathrm{R}^{\prime}$ $\mathrm{BrCH}_{2} \mathrm{COCCOOC}_{2} \mathrm{H}$ (V)
(VII) (VIII)
拿入するには 3 方法が考へられる。2 つは硝化後又はヂアジニウム 化合物とカップリングした後還元して6-位に $\mathrm{NH}_{2}$ を入れ，得たアヒ ノクロマン (V) を酸化してキ;ンとなし，還元及兩闒環によりミ ドロキシクロマン (VI) とする。第 3 の方法はプロモ化合物 (VII) を熱アルカりで加水分解するか，又は Grignard 試劑の酸化により $\mathrm{OH}$ 基を導入する。

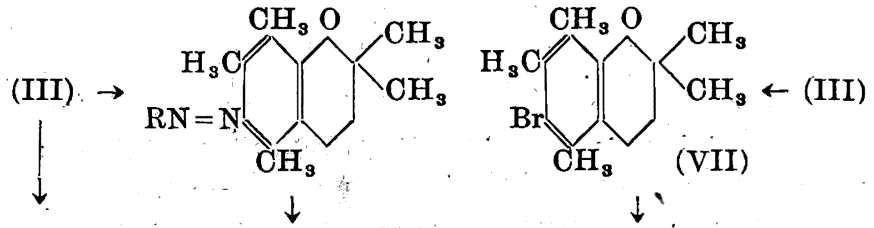

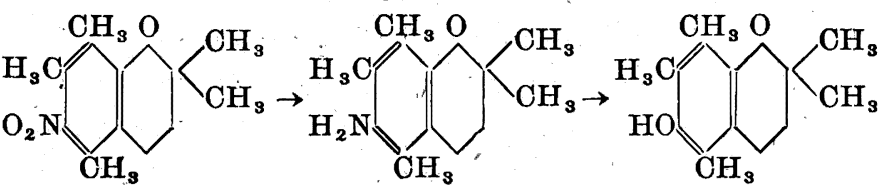

(IV)

(V)

クロマン (III) はギアゾ化スルファニル酸と着色するがカップリ

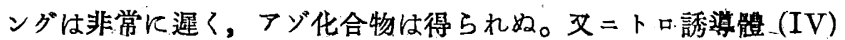

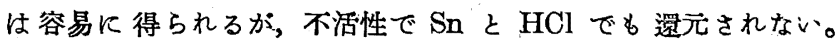
(III) の臭素化は $\mathrm{CCl}_{4}$ 中で容易に起つて真化物 (VII) となる。

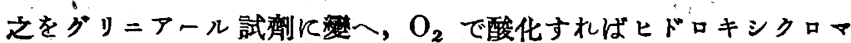
ン（VI）を惡收量で與へる。(VII) の加水分解は試みなかつた。

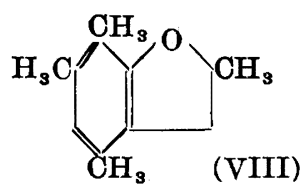

クマラン系の賽驗ではテトラメチ ルクマラン (VIII) がフェノールか らアリルェーテルを䅔て作られ，之 は容易に臭素化される。此臭化物の グリニアール試犁の酸化により少量 のヒドロキシクマランを得た。臭化物は $\mathrm{NaOH}$ と加熱すると融點 93 94 9物質を與へるが，之は 2,3,5-トリメチルフェノールであ つた。(L. I. Smith, H. H. Hoehn, H. E. Ungnade, ibid., 1939, 4, 351)

（䈎，力）（桂樹日出雄）

XII. チヒドロクマリンイグリニアール試劑の作用てクロマンの 生成 クマリンとグリニアール試劑の作用は種々の研究者により試 みられたが，反應は非常に複雜である。此複雜性はクマリンの共䡉 2 重結合による。それで還元により 2 重結合を除いたデヒドロクマ リンに就て研笁した。ギヒドロクーリン (I) とグリニアール試劑の 反應生成物はラェノール性カービノール (III) と 2,2-ギ置換クロマ ン (IV) であり，其中間に（IIa）を經るであらら。<smiles>CCOC(=O)C1(C(=O)O)C(=O)OC2(C)C(C)CCC12C(=O)O</smiles>

(L. I. Smith, W. W. Prichard, ibid., 1939, 4, 342)

（笹 力）（桂樹日出雄）

XI. クロマン及クマランは $\boldsymbol{p}$-ヒドロキシル基の導入 $m$-キシ ロヒドロキノンは具化フィチルを縮合し，トコフェロール(I)以外に 其フィチル誘導體 (II) をも生ずるが, 斯樣に $\mathrm{OH}$ 基の隣が空いて 居る時は 反應が襍稚になる。其故先ざフェノールから異節環を作 り, 其後 $p$-ヒドニキシークロマン及ークマランの合成を䳢みた。そ のモデル定驗として 2,3,5-トリメチルフェノールをイソプレンと縮 合させ，クロマン (III) を好收量で得た。此物質の6-位に OH<smiles>[R2]CC1(C)CCC(O)C(C)C1OCC</smiles>

(I) $\mathrm{R}^{\prime}=\mathrm{H}$; (II) $\mathrm{R}^{\prime}=\mathrm{C}_{29} \mathrm{H}_{39}$

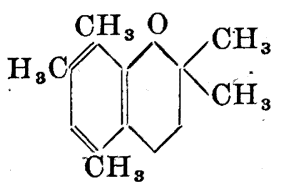

(III)<smiles>O=C1CC2CCC(C1)C(=O)C2</smiles>

(I)<smiles>[R]C1(O)Cc2ccccc2O1</smiles>

(IIa)<smiles>O=C(O)CCc1ccccc1</smiles>

(IIb)<smiles>[R]C([R])(O)CCc1ccco1</smiles>

(III)<smiles>[R]C1([R])CCc2ccccc2O1</smiles>

(IV)
其故條件を變へれば中間のケトン(IIb)を遊離出來るであらら。 此ケトンはトコフェロールの合成に利用される。然し種々の條件で そケトンは遊離出來ず，第 1 の分離生成物はカービノール(III) で あつた。てれは容易にクロマン (IV) に變化する。例いば (I) を

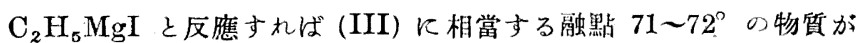
容易に得られる。此物質は酸と㟟沸する事によりクロマン(IV, $\mathrm{R}=$ $\mathrm{C}_{2} \mathrm{H}_{6}$ ) となる。 $n-\mathrm{C}_{3} \mathrm{H}_{7} \mathrm{MgCl}$ でも同樣であつた。 
トコフェロールに類似の物質变得るには $5,7,8$-トリメチルー6-ヒ ドロキシー3,4-ヂヒドロクマリン (V)から出签せ孙ばなら奴。(V)を<smiles>CC1=C(C(=O)O)C(C)(C)CCC1=O</smiles>

(V)<smiles>CCC1CCC(C)(C)OC1CO</smiles>

(VI)
$\mathrm{CH}_{3} \mathrm{MgI}$ 子作用させるとカービノール及クロマン (VI) が同樣 に得られる。(L. I. Smith, H. E. Ungnade, W. W. Prichard, ibid., 1939, 4, 358)

（侮 力）(桂樹日出雄)

アセトアルデヒドと醋酸ヴィニルの缩合 アセトアルデヒドのア ルドールへの縮合は Bodenstein (Ber., 1934, 67B, 1338; 1938, 68B, 831)によれば次の如くである。

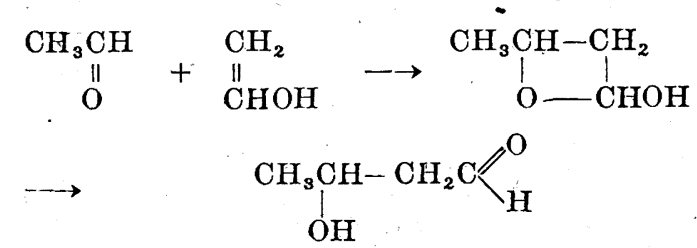

此假說から考入るとアセトアルデヒドは醋酸ヴ,ィニルと縮合して 環狀化合物 (I) を與へるであら5。金屬 Na の存在で縮合を行つ た所, 踭期に反し, $2 \mathrm{~mol}$ のアセトアルデヒドが $1 \mathrm{~mol}$ の醋酸ヴ、 ニル之縮合して化合物 (II)を與へた。(II)は加水分解によりアせ卜 アルデヒド, 醋酸及アルドールを與へる事及分子量から其㯇造を推 定した。

$\mathrm{CH}_{3} \mathrm{C}=\mathrm{O} \quad \mathrm{CH}_{2}=\mathrm{CH} \cdot \mathrm{OCOCH}_{3} \rightarrow \mathrm{CH}_{3} \mathrm{CH}-\mathrm{CH}_{2}$<smiles>CC(=O)OC1CC(C)OC(C)O1</smiles>

(II)

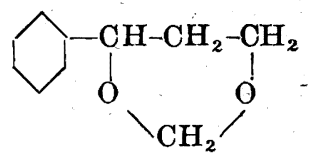

(III)
てれは Prins (C. A., 1920, 14, IC60) がフォルムアルデヒドと スチレンから得た化合物 (III) と似て居る。アセトアルデヒドの 代りに他のアルデヒドを用ひ庆所此縮合は起らなかつた。(C. S. Marvel, J. Harmon, E H. Riddle, J. Org. Chem., 1939, 4, 252)

（笽 力）

芳香族スルフォンの確認 アルキルーフェニルスルフォンの確認に 就ては Ipatieff 及 Friedman ( $J$. Amêrr. Chem. Sor., 1939, 61, 684)，の最近の報告があるが，本報では10 個の芳香族スルフォンに 關して研究した。殆ど總てのスルフォンはアルキル基を有する故 先づ水醋中で $\mathrm{CrO}_{3}$ で酸化してカルボン酸とした。然しカルボン 酸の融點は高き飞過ぎ，例へばフェニルーp-カルボキシスェニルスル フォンは 266 268 であるから不適當である。此難點を除く篇無水 アルコール中で硫酸でェステル化すると融點は低くなり，例へば フェニルートーカルブェトキシフェニルスルフォンの融點は 70〜 70.5 で出る。然し最良の確認法は确化によりこト口誘導體上なし其融點 を測定する事である。矿化は濃硫酸中で容易に行はれ，好收量でぎ ニ下ロ化合物を與へる。10個のスルフォンのカルボン酸、エステル 及ギニトロスルフォンの融點の表を揭げた。(C. A. Buehler, J. E. Masters, J. Org. (hem., 1939, 4, 261) (镇. 力)

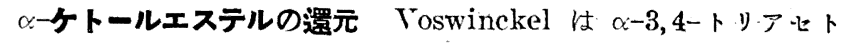
キシアセトフェノン（融點 $95^{\circ} \mathrm{C}$ ) 及その八ロゲン化物を錫と醋酸で
還元して心-3,4-トリアセトキシ・ェチルベンゾール及ぞのハロゲン 化物を得をとしたのに反し, 著者等は一 $\mathrm{CO}-\mathrm{CH}_{2} \mathrm{X}$ なるケトンの八 ロゲン化物の還元に於ては一般に理論的に考へても-CO- $\mathrm{CH}_{3}$ 或 はー- $\mathrm{CH}_{2}-\mathrm{CH}_{3}$ にはなるが- $\mathrm{CH}_{2}-\mathrm{CH}_{2} \mathrm{X}$ には還元されないとし，嘪

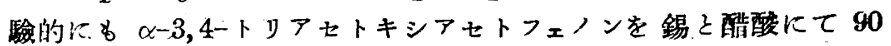
${ }^{\circ} \mathrm{C}$ にて還元し 3,4-ヂアゼトシアセトフェノン $(\mathrm{A})$ を得て夯の如 く確認し, 之を反駁してみる。(A) の融點 $85^{\circ} \mathrm{C}$

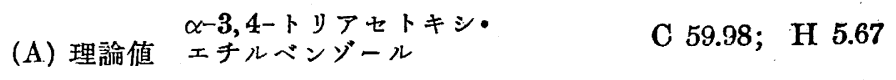
3,4-ヂアセトキシ・アセトフェノン C 61.01；H 5.12

實驗値 C $61.2 n ; \mathrm{H} 5.47$

セミカルバゾーン (アルュールより再結晶) 融點 $212 \sim 213^{\circ} \mathrm{C}$ $\mathrm{C}_{14} \mathrm{H}_{12} \mathrm{~N}_{3} \mathrm{O}_{5} \mathrm{~K}$

理論值 C 53.22; H $5.16 ; \quad \mathrm{N} 14.32$

實驗值 C 53.00； H 5.25; N 14.23

アセトカテコールより得た 3,4 -デアセトキシアセトフェノンのセ ミカルバン゙ーン之湿融, 降下を示さず。

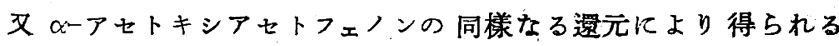
ものはフェネチルアルコールに非ずしてアセトフェ !ン $(80 \%$ ；セミ カルバン゙ン $201^{\circ} \mathrm{C}$ ) であるとしてるる。(L. S. Birnbaum \& G. Powell, J. Org. Chem., 1939, May, 139) (山口昌夫) (井 本)

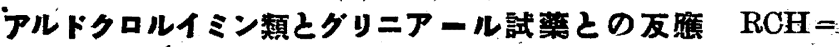
$\mathrm{NX}$ と盤基との反應に相關連し著者等は之とグリニアール試藥と の反應について報告, アルドクロルイミン類 $(-\mathrm{CH}=\mathrm{NCl})$ との 應は少くとも次の 3 つの場合が起りらるとし，

i) $\mathrm{H}$ 及 $\mathrm{Cl}$ の脫離によるニトリルの生成

ii） $\mathrm{NCl}$ 基飞於ける $\mathrm{N}$ より $\mathrm{Cl}$ の脫離

iii）二重結合に附加する場合

而して iii）の場合は朋かに起り得ないとし，i）及 ii）の場合が 次式の如く起り得る事が有力であるとアルドンロルイミン類とエチ ルー, フェニルー, $p$-クロルフェニル-MgBr と, の反應に於て認めて るる。

i) $\mathrm{RCH}=\mathrm{NCl}+\mathrm{R}^{\prime} \mathrm{MgX} \rightarrow \mathrm{RCN}+\mathrm{R}^{\prime} \mathrm{H}+\mathrm{MgXCl}$

ii) $\mathrm{RCH}=\mathrm{NCl}+\mathrm{R}^{\prime} \mathrm{MgX} \rightarrow \mathrm{RCH}=\mathrm{N}-\mathrm{MgX}+\mathrm{R}^{\prime} \mathrm{Cl}$

i）と ii）の反應に於るニトリルと $\mathrm{N}-\mathrm{Mg}$ 化合物の生成量は㰠表 の如くである。

\begin{tabular}{|c|c|c|c|c|}
\hline \multirow{2}{*}{$\begin{array}{l}\text { ベンツァール } \\
\text { クロルイミン }\end{array}$} & \multirow{2}{*}{$\begin{array}{l}\text { グリ } \\
\text { 試藥 }\end{array}$} & \multirow{2}{*}{$\begin{array}{l}\text { 反應 } \\
\text { 溫度 }\end{array}$} & 得 & \multirow{2}{*}{$\overbrace{\mathrm{RCH}=\mathrm{NM}}^{\text {量 }} \mathrm{X}$} \\
\hline & & & $\mathrm{R} \cdot \overline{\mathrm{CN}}$ & \\
\hline 2-クロル- & $\mathrm{C}_{2} \mathrm{H}_{5} \mathrm{Mg} \cdot \mathrm{Br}$ & $-45^{\circ} \mathrm{C}$ & 13 & 43 \\
\hline 4-メトキシー & II & $0^{\circ} \mathrm{C}$ & 17 & 50 \\
\hline 4-クロルー & $" 1$ & $0^{\circ} \mathrm{C}$ & 20 & 45 \\
\hline 4-クロルー & "I & $23 \sim 28^{\circ}$ & 34 & 45 \\
\hline 4-クロルー & $\mathrm{C}_{6} \mathrm{H}_{6} \mathrm{Mg} \cdot \mathrm{Br}$ & $0^{\circ}$ & 10 & 61 \\
\hline $4-ク ロ ル ー$ & $\mathrm{P}-\mathrm{Cl}-\mathrm{C}_{6} \mathrm{H}_{4} \mathrm{Mg} \cdot \mathrm{B}$ & $0^{\circ}$ & 5 & 18 \\
\hline
\end{tabular}

上表に依て見乃る ii) の反應が主に起るらしい。

又グリニアール試藥と同樣フェニルリチウム（０.25モル）は 4-ク ロルベンツァルクロルイミン (100cc) そ反應しニトリルを $\mathrm{N}-\mathbf{L i}$ 化合物交與一，後者沬加水分解によりアルデヒド（得量 $34 \%$ ：理 諭）を生ずとしての外 i）の反應をイオン式により說明を與へてる る。(J. W. Lemaister, A. E. Rainsford \& C. R. Hauser, J. Org. Chem., 1939, May. 106 110) (山口昌夫) (井 本)

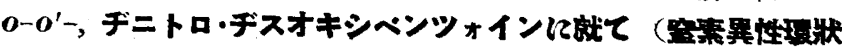
體に關する 44 報） 1897 年に A. Reissertはいーニトッ・フェニル・ ブレンットラウベン酸(I) の酸化に依り融點 $160^{\circ} \mathrm{C}$ ののを得(II) でむるとした $(B, 1896,30,1044)$ が, 其後著者等は (II)の No 
を僈元且閉環せしめデ・インドリール，或はデヒドロ・エピンドリン を得んとし (I) $0^{\circ}$ にてクロルカルク溶液にて酸化を行つた所: 豫期に反し (II) は得られず分析の結果 $\mathrm{C}_{14} \mathrm{H}_{10} \mathrm{O}_{3} \mathrm{~N}_{2}$ なる結果を 得, 0 - $0^{\prime}$-ヂニトロ・デスオキシベンツォイン (III) (アルコール及ア ルニール・醋酸エステルより再結晶融點 $\left.166^{\circ}\right)$ とした。以下之の證 明を行ひ (I) の酸化により生ずるものは (II) と非ずして(III)なり と䋺言した。<smiles>O=C(O)CC1CCCC1[N+](=O)[O-]</smiles>

(I)<smiles>O=C(CC1CCCCC1[N+](=O)[O-])C1CCCCC1[N+](=O)[O-]</smiles>

(II)
酸化物 (III) なるすのを Rarey-Ni，火て接觸還元を行ひ; 觸媒 の量に從でトロ基の還宇のみならず更に澤山の $\mathbf{H}$ が消費され異 つた2つのアミン性のものを得, 溶解度の差飞依つて分離した。

1 つは難溶性で結晶と得られアルコールょり再結晶し融點 $154^{\circ}$ の 2-(o-アミン・フェニル) インドール (V).を得を(III)より 12 ヶの H の滑費にょり (IV) を生じ, 更に (IV)ょり1分子力水か そんで生じたのである。A. Kliegl 及 K. Hass 、(B., 1911, 44, -1216) К從ひ 0 - ○'-デアミノトーランを濃硫酸處理にて得られる(V) と混融し、て確認, 更火各 (V) より得られるアセチル誘導體は共に 同じであるとしてねる。

他の一は (V) は取づ液より得られる他の還元物を更に接觸

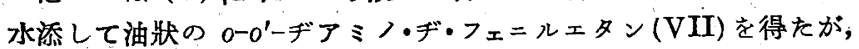
てのヂ・アセチル誘導體 (VIII) は $250^{\circ}$ Kて跧融し逆に之を $\mathrm{HCl}$

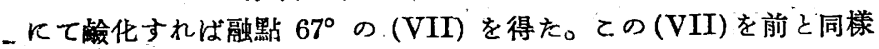
oーo'ーヂニトロトーランの接觸還元にて得られる $o^{\prime} o^{\prime}-$ ヂニトロ・ス チルベンを Na とアミルアルコールトて還元して得たるのと比較 同一物なりとして (I)より (III) の生ずる事を認めた。
(III)<smiles>CCC1CCCCC1N</smiles>

(IV)<smiles>NC1CCCCC1O</smiles><smiles>NC1CCCCC1C1=CC2CCCCC2N1</smiles>

(V)
の蒸氣さなし冷却して金屬を得る。爐の中央より稍上方に蒸氣帶 (Vapor ring)，むりて稍太くこ〉より冷却器に接纉する，電極は熷 の上下にあり 2 組の三相にて 各包路は 275〜250 ヴォルト 1800〜 2000 アンン゚アでやり本均溫度は $1200^{\circ} \mathrm{C}$ である。計算上 $36 \mathrm{lb}$ の 燒結物に對し $4.5 \mathrm{lb}$ のコークス（還元劑）で充分なるも此作業で は $16 \mathrm{lb}$ も混じて裴入する。之は電氣傅導度をよくし廢がスを $\mathrm{CO}$ に富ましめ $\left(82 \% \mathrm{CO}, 1.6 \% \mathrm{CO}_{2}, 1.4 \% \mathrm{O}_{2}, 15 \% \mathrm{~N}_{2}\right)$ 此がスを豫 熱其他に利用するためで块して損失にならない。コークスの比較的 多いものを触の中心に裝入する樣にし妶に“Core”を生ぜしめ 電流の通路を安定ならしめ，從て局部的或は一時的の過熱なく一

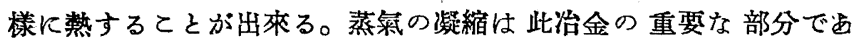
る。此方法では約 $850^{\circ} \mathrm{C}$ (露點 $830^{\circ} \mathrm{C}$ ) の $\mathrm{Zn}$ 蒸氣及. $\mathrm{CO}$ の混 合物を $580^{\circ} \sim 650^{\circ} \mathrm{C}$ に保つた焒融亞鉛の中を通し凝縮せしめ何之 を通過した $\mathrm{Zn}$ 分は水洗して blue powder として包收し，再び爐 ス入れる。此細粉の量は主に金屬浴の溫度に關保する。普通の作業 では $550^{\circ} \mathrm{C}$ を下ら樣に注意する, 又此部分で多量の謷を放散せ しめねばならぬととを併せ洘へるとを，この浴のライニングには相 當の技術と費用を必要とする。結局此治金法の成功した重要なポイ ントは（1）爐への裝大，（2）コンデンサー，の 2 點にある。(George F. Weaton and Carlton G. Long, Met. Ind., 1939, 5, 99)

(安藤德一) (武 井)

キューパ島産マソガン鏞 マンガンけ製鋼の際脫酸劑, 脫硫劑と して重要な役割を演ずる。米國に於る Mn 不足の問題はギューバ 島座貧マンガン鑛を Cuban-American-Corp. の手で開發するとと により解决に導いた。1931 年にはキューバ産 Mn は米國使用量の 1\%に過ざなかつたが 1938 年には $27 \%$ に及んだ。同島の Mn 鏆

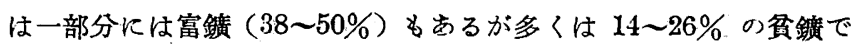
ある。1930年以來多數の學者により比重選銈及浮遊選鐄の兩方面の 研究が始められ結局浮遊選鐄法が倎る結論となり，\$1,2;0,000の 巨費を投じて大規模に工業化せられ經濟的に行はれつ」ある。比重 選銓の不利なる點は，本來の $\mathrm{Mn}$ 鑛ならば比重 4.6〜4.8 であるの

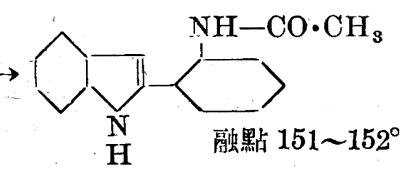

(VI)<smiles>COC(=O)NC1CCCCC1CCC1CCCCC1NC(=O)OC</smiles>

(VIII) に此鏡石は化合水の 關係より 2.7〜3.0. К下り母岩と分つと と困難で出る。1935 年特許と なりしとの浮選法の 概要灭の 如L。 1）粗粉碎, 最大至 4时, 2) 細粉碎 (A) Symons cones 1/2 时, (B) ボールミル 25\% を，100Mesh，3）游選鑛

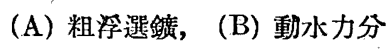
離, (C) 精浮選鐻, (D) 再精浮 選鐄，(E) 尾鑛の反復精浮選,
(P. Ruggli \& A. Dinger, Helv., 1939, 22, 908)

\section{7. 酸，アルカリ及肥料}

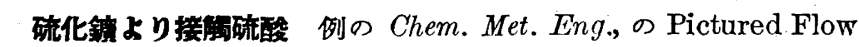
Sheet 欄に於て 8 月號には硫化鐄焙燒上り接觸硫酸の出荷まで俓 路圖及米國の Monsanto Chemical Co. の實物寫䛧を揭載してる る。(Chem. Met. Eng., 1939, 477)

（上田鹤吉

\section{8、鑛物，冶金及金工}

亞鉛の電熱治金 St. Joseph Lead Comp.の亞鉛電潐冶金法は G. F. Weaton, Trans. A.I.M. E., 1936, 121, 599 飞發表されて 居るが，茲では其作業結果を報告してるる。原鉵を焙燒し次で之を

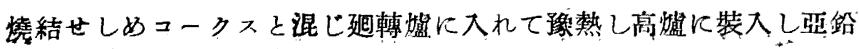

(山口昌夫) (井 本)

\section{4)精選鑪の沈澱池による處理,}

5) 筧結處理 (Dwight-Lloyd 燒結機による)。今日ではえに更に改 良を加一 13 ～18\%のののより $50 \%$ の燒結鐄を生產し，外國の高 級品 ( $45 \%$ ～52\%) に炕敵するものである。份此選鈸 法により米 國內地産の貧鑛を處理する樣に京九ば $\mathrm{Mn}$ 不足の心配は、最早問題 ではない。其意味に於ても此選鑛法の成功は重要な意義がある。 (F. S. Norcross, Min, and Met., 1939, 20, 380)

(安藤德一) (武 井)

\section{0. セメント及建築材料}

セメントモルタルの乾㷄收縮の小型試驗法 僅少の試料を以て收 縮試驗を行子篇 $1^{\prime \prime} \times 1^{\prime \prime} \times 1^{\prime \prime}$ の立方形のセメントモルタル試驗 體を成形し, 一定期間盖生後乾燥し其容積收縮を測定士万裴置を考 策し，本裝置の测定値を通常行はれて居る $12^{\prime \prime} \times 2^{\prime \prime} \times 2^{\prime \prime}$ の梁型試 驗體の線收縮測定值との比較試驗を行つた結果，雨者は直線關係に 
在り梁型の收維值の小型立少型の收縮值に對する比は 0.15 となり,

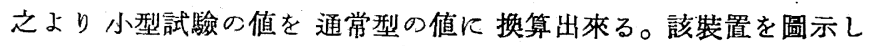
試驗操作の惯際並に試铪成績を揭げた。而して本裝置の精度は士 0.002cc である。(R. W. Nurse, J. Soc. Chem. Ind., 1939, 58, 1, 37)

(古筊德二) (村 上)

セメントの粉末度の比較試駩 本稿は大堰堤に關する英國委員會 中の特殊セメント小委員會に於て低熱セメントの試驗方法の一部分 をなすものにして英國 Building Research Stationより共通試料 を䢪り各國各試驗所に於て各種の微粉湘定裴置により試驗し, 其結 果照査し再計算し比較に便ならしめたるのである。試料は2 種の ポルトランドセメントと1種の白色セメントにして參加國は佛, 獨, 英, 米及瑞典にして使用裝㯰は Wagner Turbidimeter, Air Elutriator, Andreasen Pipelte, Photoelectric Turbidimeterなり。 此等試擥成績を綜合するに粒子分布曲線及比表面栍は (1)粒子徑の 計算基礎，(2) 直接湘定を行はない最小粒子群の本均徑の假定，(3) 試驗操作等化左右される。依て粒子徑にストークス徑を探り，最小 粒子群 $(7.5 \mu$ 以下) の本均徑を $3.8 \mu$ と定め, 最大粒徑 $25 \mu$ 迄の 範圈內に於る各試驗室の成績より比表面積を求め之各試驗方法 每に本均すれば Andreasen 法が Wagner 法より稍大きな值を示 す樣なれど管る1試驗室の試驗誤差の範圍に在り，建築研究所の結 果によるとセメントの分散方法に基因するるのらしい。顯微鏡實測 粒子徑に基く比表面栍はストークス徑より計算せるものより約 10 \%低き值を示す，粒子分布曲線は比表面積よりは各試驗室の偏差が 大きい樣である。之は比重の假定の影響が比表面積の場合よりは顯 著に㗽くためである。要するに分散方法さ一嚴正に規定すれば各試 羷の，結果はもつと近接せしめ得る。而して試驗結果を直接比較し得 る䉆には粒子螌圍と最小粒子群の粒徑の假定を一定する要あり。 F. M. Lea, J.soc. Chem. Ind., 1939, 58, 4, 146)

(占籍德二) (村 .上)

石灰質物中の㞸酸監のガス容栍法による定量 種々の石灰質構造 材料に於て極少量の試料を以て簡單に迅速に而专 士0.2mg の精確 度に於て $\mathrm{CO}_{2}$ の定量を必要々する場合が屡々ある。在來の方法は かくの如き目的に不適當心れば新法を提案した。荘置は小字型校付 ガラス反隹管々水銀を充した U 字型がス容積測定器とを毛細管で 連絡したもので, 其操作は校付卜字管の底に試料 $0.02 \sim 0.2 \mathrm{~g}$ を探り, 之に $1.5 \mathrm{~g}$ の硫酸カリを加一校部に・ 1.2cc の硫酸を入れた後之をガ

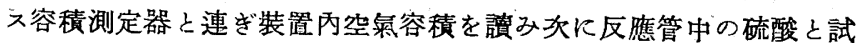
料を接觸せしめ加溫して $\mathrm{CO}_{2}$ ガスを追出し原溫度に泠却後遊離し

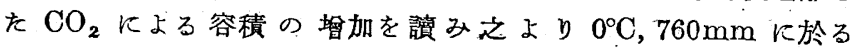
$\mathrm{CO}_{2}$ の密度を $1.977 \mathrm{~g} / l$ として $\mathrm{CO}_{2}$ の 重量を算出する。本法の應 用籍園は硫酸との反應に於て $\mathrm{CO}_{2}$ 又は $\mathrm{H}_{2} \mathrm{\theta}$ 以外の子のを發生せ ざるものに限定され石灰, 石灰石, ポルトランドセメンント，灰砂煉 瓦, 其他類似の物に適する。(G. E. Bessèy, J. Soc. Chem. Ind., $1939,58,5,178)$

(古筊德二) (村 上)

\section{1. 石油及アスファルト}

發生期の臨化アルミニウムに依るパラフィンのクラッキング 固

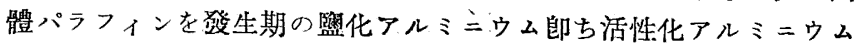

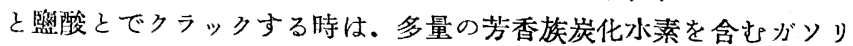
ンを生成するも，無水監化アルミニウえでは芳香族のないガンリン を生ずると言ふ Otin 及 Dima の赛驗には疑閒の點がある。それで 著者等は天然パラフィン及 Fischer-Tropsch 工場で得た Kogasin

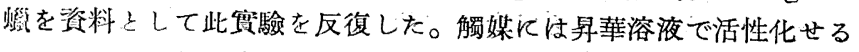

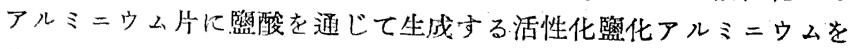

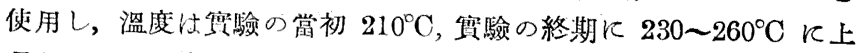
輣した。又反應時間は使用するパラフィン量に雔じて 50〜 120 時間 である。其結果を次表に示す。

\begin{tabular}{|c|c|c|c|c|c|c|c|c|c|}
\hline \multirow{3}{*}{$\begin{array}{l}\text { 實殮 } \\
\text { 番號 }\end{array}$} & \multirow{3}{*}{ 資 } & \multirow{3}{*}{\multicolumn{2}{|c|}{ 料. }} & \multirow{3}{*}{$\begin{array}{c}\text { 活性 } \\
\mathrm{Al} \\
\mathrm{g}\end{array}$} & \multirow{2}{*}{$\begin{array}{l}\text { 反應 } \\
\text { 溫度 }\end{array}$} & \multirow{3}{*}{$\begin{array}{l}\text { 反應 } \\
\text { 時間 } \\
\text { (時) }\end{array}$} & \multicolumn{2}{|c|}{ 生成物 } & \multirow{3}{*}{$\begin{array}{l}\text { 全ガス } \\
\text { 十ガン } \\
\text { リ立 } \\
\text { wt\% }\end{array}$} \\
\hline & & & & & & & कบy & ガス & \\
\hline & & & & & & & 0 & 000 & \\
\hline 1 & $500 \mathrm{~g}=$ & けシン & 蠝 & 45 & $210 \sim 30$ & 76 & 319.9 & 82.2 & 80.5 \\
\hline 2 & 350. $天$ & 然 & 释 & 15 & $210 \sim 30$ & 49 & 140.1 & 36.7 & 51.0 \\
\hline 3 & $1,510 \mathrm{~g}$ 天 & 然 & 蠟 & 100 & $220 \sim 60$ & 118 & 897.6 & 163.5 & 70.8 \\
\hline 4 & $250 \mathrm{~g}$ 天 & 经 & 睢 & 25 & $210 \sim 40$ & 121 & 104.4 & 28.5 & 53.0 \\
\hline 5 & $324 \mathrm{~g}$ 天 & 然 & 蠟 & 12 & $200 \sim 30$ & 7 & 108.0 & 129.4 & 73.0 \\
\hline
\end{tabular}

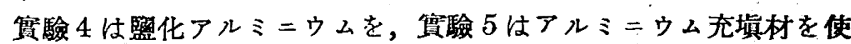
用した實驗である。實驗 3 の收量が實驗 2 飞比較して多量なのは宽 驗終期の盜度が高いからである。同一條件ではコガシン舆は天然パ ラフィンよりも迅速にクラックするらしい。アルミニウム充填材は アルミニウムょり当活性が高く, 從て嘪驗5 亿於てはクラッキング が烈しく生起し, 僅か 7 時間で多量のガスが生成する。

液狀生成油は菏性洗临, 水洗涤して乾燥し再蒸溜した。其の $\mathrm{P}_{2} \mathrm{O}_{5}$ $-\mathrm{H}_{2} \mathrm{SO}_{4}$ 處理, 又は酒精力! 處理, 又は水素添加前後の比重, 屈 折竹, Wijs 沃素熘，アニリン點等を試驗の結果，分解溜分は脂 肪族性で，芳香族もデフテン類も含むないことを認めた。併し，再 蒸溜後の分解溜分, 特に沸點 $70^{\circ} \mathrm{C}$ 以上の溜分中下廐化アルキルが 存在し，之に依て溜分の物理恒數及硫酸吸收量が芳香族炭化水素の 存在する如き值を示す。

$70 \sim 90^{\circ} \mathrm{C}$ 溜分を接觸水素添加して䇴素を完全除去すると,分解溜 分は脂肪族性を示すや5反成る。其際に於る屈折率及アニーリン點 變化から，ナフテン炭化水素の存在否定出來る。(H. Koch und H. Steinbrink, Brenn.-Chem., 1939, 20, 147)

\section{(小林良之助)}

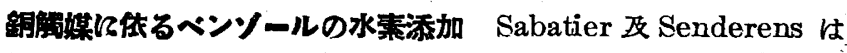
銅はベンゾール水素添加の觸媒にならないと報告してるる。後 Pease 及 Purdum は銅が $225^{\circ} \mathrm{C}$ 及常壓でベンジール水素添加を促 淮するてとを認めた。著者等も銅を精煉して活性な銅解媒と不活性 な銅觸䍀との表面を检へてみた。

C. P. (Chemical Pure) 酸化銅及炭酸銅を邆元して造つた銅觸媒 は, $225^{\circ} \mathrm{C}$ 及常厭で, 90 秒間にベンゾール 30〜50\% を水素添加し てシクロへキサンKする。此等の觸媒は凡て不純物を含み，其主成 分はニッケルである。純粹な銅觸媒は監基性炭酸監又は水酸化物を 炭酸アンモニゥム又は水酸化アンモニウムで沈泥して生成出來る。 其沈澱を乾燥し水素還元する。或種純銅觸媒を造るのには $\mathrm{Cu}$ $\mathrm{SO}_{4} \cdot 5 \mathrm{H}_{2} \mathrm{O}$ をも原料にして子良い。

水酸化物及炭酸留加ら造つた純銅䚪媒は $225^{\circ} \mathrm{C} に 240 \sim 440$ 秒接 觸してもベンゾールの $1 \%$ を水素添加するに過を゙い。銅イオンを 水素還元して大なる微分結晶として得られる純銅觸媒は，310 秒接 觸してもベンゾールを水素添加出來ない。

初期水素埾が $100 \mathrm{~kg} / \mathrm{cm}^{2}$ 下ではカールバウム製酸化銅から造つ た銅觸媒は，ガラスの內張りしたボンブでベンヅールを， $350^{\circ} \mathrm{C} K$ 12 時間に全部水素添加した。同一條件で沈㴬法で造つた种銅触媒 に依ると，70９7\%水素添加する。併し加揆水素で銅イオンを摆元 して造つそ純銅觸媒は; $350^{\circ} \mathrm{C}$ の初期厭 $100 \mathrm{~kg} / \mathrm{cm}^{2}$ で 12 時間し てもべンゾールを水素添加出來ない。

不純な酸化銅から造つた銅解媒の活性は, 酸化銅の僈元温度の上 界につれて又還元時間の延長につれて低隇する。水素流速を晢して も活性け低下寸る。䩻に依る不活性作用は不可逆的であつて 350 $400^{\circ} \mathrm{C}$ て迅速に生起する。

活性觸缚及不活性觸媒の表面を顯徽鏡て觀察するに，活性表面は 海綿狀の微分結晶があつて，其間几多数の裂目が認められる。郎ら 不活性觸䍀に比較して表面積が大できる。此温別は更に表面を土未 ナチオンで測定して確認した。(Ipatieff, Corson \& Kurbatov, $J$. Phys. Chem., 1939, 43, 589)

(小林良之助) 
アルカン類及チクロアルカン類の製造及物理恒數 24 種の液狀 パラフィン異性體 (アルカン類) 及 6 種のナフテン類（チクロアル カン類) を純粹に各 $1 \mathrm{~kg}$ 生成して, 其物理恒數を决定した。5ち 重要なるものを表示する。

\begin{tabular}{|c|c|c|c|c|c|c|c|}
\hline 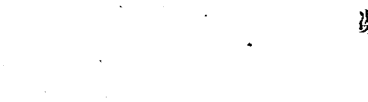 & $\begin{array}{c}\text { 凝固點 } \\
{ }^{\circ} \mathrm{C}\end{array}$ & $\begin{array}{c}\text { 融 點 } \\
{ }^{\circ} \mathrm{C}\end{array}$ & $\begin{array}{c}\text { 轉移點 } \\
{ }^{2} \mathrm{C}\end{array}$ & $\begin{array}{c}\text { 沸 點 } \\
(760 \mathrm{~mm}) \\
{ }^{C} \mathrm{C}\end{array}$ & $\begin{array}{l}\text { 比重 } \\
\text { at } 20^{\circ} \mathrm{C}\end{array}$ & $\begin{array}{l}\text { 康折率 } \\
\text { at20 C } \\
\mathrm{d}^{\circ} \times(5976)\end{array}$ & $\begin{array}{l}\text { 臨界共盗 } \\
\text { 溫度, }> \\
=リ ン 00\end{array}$ \\
\hline \multicolumn{8}{|l|}{ パラフィン類 } \\
\hline 正 ペンタン & -129.7 & - & -- & 35.95 & 0.62624 & 1.35769 & 71.7 \\
\hline 2-メチル・ブタン & -160.6 & - & 一 & 27.80 & 0.61972 & 396 & 78.9 \\
\hline 正へキサン & -95.5 & - & 一 & 68.75 & 0.65943 & 1.37499 & 69.1 \\
\hline 2-メチル・ペンタン & ガラス狀 & - & - & 60.30 & 0.65316 & 156 & 73.9 \\
\hline 3-メチル・ペンタン & ガラス狀 & - & : - & 63.30 & 0.66435 & 62 & 69.3 \\
\hline 2・2-ヂメチル・ブタン & -100.5 & - & 約 -146 & 49.70 & $0.64919^{-}$ & & 1.2 \\
\hline 2・3ーギメチル・ブタン & -128.5 & -128.2 & 約 -142 & 58.05 & 0.66166 & 1.37509 & 71.9 \\
\hline 正 & -90.8 & - & - & 98.40 & 0.68378 & 1.38775 & 70.1 \\
\hline 2-メチルへキサン & -118.5 & -118.2 & - & 90.10 & 0.67869 & 1.38498 & 73.6 \\
\hline 2・2-ヂメチル・ペンタン & -124.0 & - & - & 79.30 & 0.67388 & 1.38226 & 78.3 \\
\hline 2•3ーヂメチル・ペンタン(不均) & ガラス状 & - & - & 89.80 & 0.69514 & 1.39210 & 68.0 \\
\hline 2・4-ヂメチル・ペンタン & -119.1 & - & - & 80.60 & 0.67275 & 1.38153 & 78.7 \\
\hline 3:3-ヂメチル・ペンタン & -135.7 & -125.0 & - & 86.10 & 0.69330 & 1.39097 & 69.7 \\
\hline 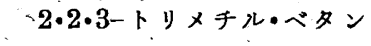 & -26.3 & - & 約 -156 & 81.00 & 0.69007 & 1.38954 & 72.2 \\
\hline 正オクタン & -56.8 & -56.8 & - & 125.75 & 0.70280 & $1: 39770$ & 72.1 \\
\hline 3ーメチル・ヘブタシ(不均) & ガラス狀 & - & - & 119.05 & 0.70584 & 1.39856 & 72.2 \\
\hline 2.3ーギメテル・ヘキサン(不均) & " & - & -- & 115.80 & 0.71234 & 1.40136 & 70.6 \\
\hline 2.5ーデメチル・へキサン & -94.0 & - & 一 & 109.25 & 0.69426 & 1.39285 & 78.0 \\
\hline 3.4ーヂメチル・ヘキサン(不均) & ガラスス狀 & - & - & 117.85 & 0.71951 & 1.40436 & 68.0 \\
\hline $2.2 \cdot 3+ト$ リチル・ペンタン(不均 & 匈)ガラス狀 & - & - & 110.05 & 0.71613 & 1.40302 & 70.8 \\
\hline 2.2.4ートリメチル・ペンタン & -107.6 & - & - & 99.10 & 0.69196 & 1.39151 & 80.4 \\
\hline ターメチル・3-エチル・ペンタン & -91.1 & -90.9 & - & 118.35 & 0.72742 & 1.40790 & 65.9 \\
\hline 正ノナ ナ & -53.8 & -53.7 & - & 150.70 & 0.71808 & 1.40561 & 74.9 \\
\hline 正へキサデカン & +17.9 & +17.9 & - & - & 0.77387 & 1.43470 & - \\
\hline \multicolumn{8}{|l|}{ ナフテン類 } \\
\hline エチル・チクロブタン & -143.2 & 一 & - & 70.70 & 0.72787 & 1.40214 & 38.7 \\
\hline チクロペンタン & -94.3 & $\ldots$ & -151.5 & 49.20 & 0.74542 & 1.40649 & 17.4 \\
\hline メチル・チクロペンタン & -142.7 & -142.4 & - & 71.85 & 0.74869 & 1.40983 & 34.0 \\
\hline チクロヘギンン & +6.4 & . - & -87.0 & 80.80 & 0.77867 & 1.42630 & 30.4 \\
\hline メチル・チクロヘキサン & -126.4 & -126.3 & - & 100.80 & 0.76944 & 1.42310 & 40.3 \\
\hline イソプロピル・チクロヘキサン & -89.8 & $-\quad 89.3$ & - & 154.50 & 0.80232 & 1.44095 & 48.9 \\
\hline
\end{tabular}

俔ガソリン製造に對し重要なる役割を演じ，原油より收得するがン リンの收率を褧に 7〜8\% 增加する事が出來る。(G. F. Fitzgerald, Chem. \& Met. Eng., 1939, 46, 196)－（原泰信）(小林)

充堨管に依るガス油の氣相クラッキング ガス油を管及充拄管 を使用して氣相クラッキングし，其 際層流改混流火依て如何なる效果を 及ほすかを研究した。混流传る熱 傳導率の上昇と, 溫度分布の均一化 はクラッキングに際し比較的低溫に 於て，低沸點溜分の生成及そのオレ フィン含量を著しく增大し，特に $600 \sim 700^{\circ} \mathrm{C}$ 亿於て顯著である。又 湿流狀驡にて氣相クラッキングする 場合恃芳香族含量も多く，特飞滈溫 に於て其傾向が著しい。斯の如く蒸 氣流の形態は, 分解生成油の成分に 著しく影響する。層流の場合, 郎ち 架管老使用して氣相クラッキングし た場合はガス油の1包通過に依り， 600 及 $650^{\circ} \mathrm{C}$ 几於て夫々 $8.4 \%$ 及 $16.1 \%$ の終點 $205^{\circ} \mathrm{C}$ ガソリンを收 得した。之に對し混流の場合, 即ち 充填管を使用しを場合は，同栐の條 件に於て夫ア $16.0 \%$ 及 $22.4 \%$ であ つを。又 $800^{\circ} \mathrm{C}$ 飞於ては空管, 充坨 管何れの場合子終點 $205^{\circ} \mathrm{C}$ ガソリ ンの收量は $25 \%$ であった。然し作 ら後者に於ては, 生成ガソリン中に ベンゾール 20\%,トルオール20\% を含有せるる，前者に於てはベンゾ ール及トルオールの含量は夫々 $15 \%$ 及 $5 \%$ К過ざなかつた。更に生成せ る分解ガスを原料油蒸氮にりサイク ルせしめたる結果，ガソリン收量は 增加甘ず，芳香族含量が著しく減少 した。(A. Cambron \& C. H. Bay+ ley, Can. J. Research, 1939, 17 B, 23)

(原 泰信) (小林)

正パラフィン岸化水素の融點之分子量之の關係 一同族體に於る 融點々炭素原子數との關保は興味ある問題であるが, 特に正パラフ

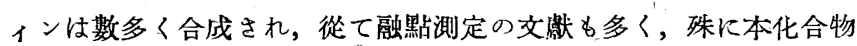
に於ては融點は重要なる性質なる故上述の關保は石油化學上甚だ興 味深い。

正パラフィンの融點と炭素原子數或は分子量との關保式は, 既に Austin, Garner, Merckel, Moullin 等に依て提出された。之等 の關保式に依る計算値と嘪測値は，或範圍に依て良く一致するも不 滿足なる結果を與一る事が少くない。特に低級正パラフィンに於て 甚だしい誤差を生ずる。著者は本報告に於て新たなる關係式を提出 し, 其計算値己惯測値とは $1^{\circ} \mathrm{C}$ 以内の誤差籁圍に於て一致する事 を赛證した。

今縱軸に融點を横軸に炭素原子數をとり，各對應點を順次に點経 すれば稻妻型の曲線が得られ，之を一關保式にて表す事は不可能で ある。然し乍ら炭素原子數の奇數なるもの及夫が偶數なるものは夫 夫一定曲線上に在り前者は後者に比し稍々低目の融點を示す。此等

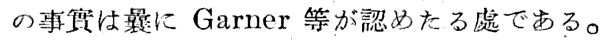

著者㤌此等 2 曲線吕 $\mathrm{C}_{22} \mathrm{H}_{46}$ 以上に於ては殆ど合致し 1 曲線と 見做し得るを以て，先づ $\mathrm{C}_{22}$ 以上に於る關係式を求めた。今融點 $T^{\circ} \mathrm{K}$ の正パラフィンの分子量を $M$ 上する時, 


$$
\frac{d M}{d T}=K \phi^{2}, \quad \phi=f(M)=a M+b
$$

なる關係が成立するものと假定する。妶に $K, a$ 及 $b$ 恒数てす る。上式を耫分整理する事に依り次式が得られる。

$$
T=\frac{1}{a K b} \cdot \frac{1}{1+\frac{b}{a M}}
$$

$T_{f}=1 / a K b, C=b / a$ 之置く来に依り,

$$
T=T_{f} \cdot \frac{1}{\left(1+\frac{C}{M}\right)}
$$

恒數 $C$ は上式に任意の 2 正パラフィンの融點及分子量を代入する 事倍て計算せられ，其本均值として，C=94.4が得られた。又此 值を上式に代大して $T_{f}=414.5^{\circ} \mathrm{K}$ を得, 從て上式は

$$
T=\frac{414.5}{\left(1+\frac{94.4}{M}\right)}=\frac{414.5 M}{(M+94.4)}
$$

式（1）に依て得たる計算值は $\mathrm{C}_{21} \mathrm{H}_{44}$ 以上の正パラフィンの融 點筫測値と $1^{\circ} \mathrm{C}$ 以內の誤差範图に於てて一致する。

更に興味ある事筫は $\mathrm{C}_{21}$ 以下の低級正バラフィンに於て，融點

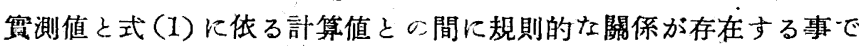
屯る。㴧ち今 $n$ を整偶数とすれば， $\mathrm{C}_{n}$ の賽測值は， $\mathrm{C}_{n+1}$ の赛測値 と, 式 (1) に依る $\mathrm{C}_{n-1}$ の計算値との算術本均に一致する。此關保 は曲線として㘣示すれば,一層时白である。

此關保より $\mathrm{C}_{21}$ 以下の正パラフィンに於ては, 融點と分子量と の間に次の關保式が成立する。

$$
T_{(n)}=\frac{1}{2}\left\{T_{(n+1)}+\frac{414.5 M_{(n-1)}}{M_{(n-1)}+94.4}\right\}
$$

茹に $n$ は任意の整偶數, $T_{(n)}$ 及 $T_{(n+1)}$ は夫々 $\mathrm{C}_{n}$ 及 $\mathrm{C}_{n+1}$ 正パラ フィンの融點 $\left({ }^{\circ} \mathrm{K}\right)$, 又 $M_{(n-1)}$ は $\mathrm{Cn}_{n-1}$ 正パラフィンの分子量を示 す。

式（2）に依り $T_{(n)}$ 㕛は $T_{(n-1)}$ の何れ多を知れば他を求める事が 出來る。式 (2) 几依る計算値は實測値々 $1^{\circ} \mathrm{C}$ 以内の誤差範園で一 致する。但し例外乞してて $\mathrm{C}_{6}$ 及 $\mathrm{C}_{7}$ は稍々誤差を生じ， $\mathrm{C}_{2}$ 及 $\mathrm{C}_{3}$ は一致しない。此等の賽測値は文獻に於て比较的信用し得べき值を 探用したが,斯る例外が存在する原因としては $\mathrm{C}_{6}$ 及 $\mathrm{C}_{7}$ の實測值が 基本曲線に乘らざる事; 及 $\mathrm{C}_{3}$ の融點が $\mathrm{C}_{1}$ 及 $\mathrm{C}_{2}$ の融點よりも 低き事等の不合理性が考へられる。(A. H. Etessam \& M. F. Sawyer, J. Inst. Pet., 1939, 25, 253 ）（原泰信）(小 林)

\section{3. 染料, 染色及紡織化學}

酸化鐵及水酸化鐵の存在に於る血波の檢出 色素化學の立場上り 與味する事柄を述ぶっ血液の一モグロビンは過酸化醭素の作用を 有す。郎ち過酸化物より酸素を遊離せしめ他の物質飞移入する働き をなす、此特殊の作用は主に芳香族化合物に限られ，芳香族化合物を 脫水素に依りヒノンに變ず。例へばベンヂジンは過酸化物の存在に

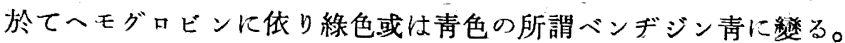
Schlenk に從一ば此染料は 1 モルのアミン, 1 モルのイミンと一衁 基酸 1 當量より成るメリキノイドであると云ふ。

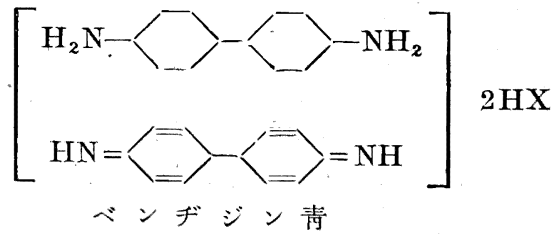

此特性を隼用し毛裂，顔面等の血液の檢出をなし得。裁制化學に於 ては血痕の豫借試驗にベンヂジンにはリウコマラカイト・グリーン を雇用し得る。
然し此際問題となるのはりウコマラカイト・グリーンが銹に依り 自然と綠色變色をなすととで，てれはベンヂジンの場合も同樣であ り此點より銹の生成中に生ずる各種酸化鐵の過酸化醭素作用に關す る研究が興味を有すること〉なる。

Schikorr飞依れば鐵銹は其時の條件に從ひ Goe'thit $(\alpha-\mathrm{FeO} \cdot \mathrm{OH})$ 又は Rubinglimmer $(\gamma-\mathrm{FeO} \cdot \mathrm{OH})$ 並に少量の $\mathrm{Fe}_{3} \mathrm{O}_{4}$ を含有する。 急速に生成した銹は水の含有量 $\mathrm{FeO} \cdot \mathrm{OH}$ 理論値より少く郎ち $\mathrm{Fe}_{3} \mathrm{O}_{4}$ を割合に多く含有する。

供試試料は無定形酸化第 2 瀻水化物及び之を $150^{\circ} \mathrm{O}$ K加熱して得 られる試料， $\alpha-\mathrm{FeO} \cdot \mathrm{OH}$ 及 $\gamma-\mathrm{FeO} \cdot \mathrm{OH}$ 並に之等より乾燥氣流中 K $300^{\circ} \mathrm{C}$ K加熱して得られる $\alpha-\mathrm{Fe}_{2} \mathrm{O}_{3}$ 及 $\gamma \mathrm{Fe}_{2} \mathrm{O}_{3}$, 其他 2 種の 合成品 $\mathrm{Fe}_{3} \mathrm{O}_{4} ; 14.0 \%$ の $\mathrm{FeO}$ を含有する Lefort 氏式試料と 27.2 $\% \mathrm{FeO}$ を舍有する Kaufman-Haber 氏式試料である。其結果を 次表に示す。

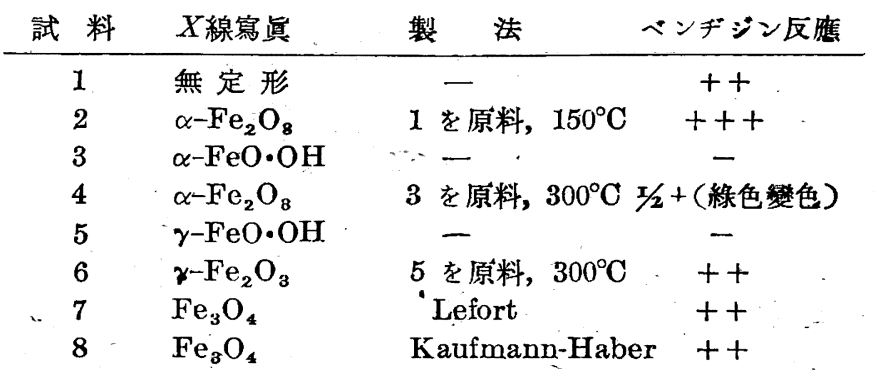

上表より見る如く結晶性の水酸化鐵 (III) はベンギジン反應がな い。之に反し無定形酸水化物並汇之より得らる〉酸化物 (III) -は强 いベンヂジン反應を呈す。結局・てれは其構造に關係するかのなら ん。鬼角銹の中には 7,8 並に場合に依ては 4,6 を含有するを以 て銹のある堭合はべンデジンに依る血清の检出疼不正確なるのであ ろ。(Oskar Glemser, Ber., 1939, 72, 1613)

(林 雄二) (永 井)

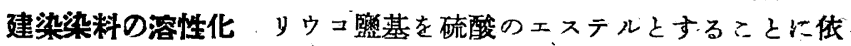
り水溶性の建染染料を得るととは周知である。䒵には硫酸エステル 化の代りにアシル化した。但しアシル基には少くとも個の造醖性 基又は第 4 アンモ二ウム化合物を有つがよい。例〜ば- $\mathrm{SO}_{3} \mathrm{Na},-\mathrm{CO}$ $\mathrm{ONa}$ 及 $-\mathrm{NH}_{2} \cdot \mathrm{HCl}$ 等。

カレドンジェードグリーンの場合の例を示せば，先づ原染料 5 部; 監化ベンゾイル・メタスルフォン酸 10 部及無水ピリデン 60 部の混 合物を $100^{\circ} \mathrm{C}$ に加熱し炭酸がスによる空氣遮断下に銅枌 2 部を加 ふ。稀薄なる炭酸りーダ溶液に可溶性となる迄同溫度に保う之圖 の如き䅇造と考へられる生成物を得る。佾 I. G.の E. P. 497327 參照，

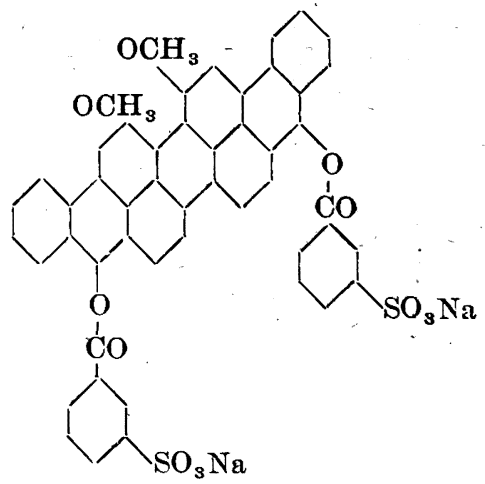

(Suc. Dyers and Colourists, 1939, 55, 274)

(林 雄二) (永 乘)

有機弗羔化合物 有機弗素化合物怡數年來技行方面に於て重要性 を示すに至つた。著者等は監化物より有機张素化合物を製する際從 來用ひられた $\mathrm{SbF}_{3}$ を用ふる代りに盗石と硫酸より容易に製せら 
れる無水弗化水案酸を用ふる事に成功した。ヒドロキシル基及アミ 基の代り下弗素を入机る事著著等に依て行注れ，且又 $\mathrm{HF}$ を

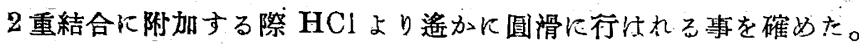
次に著者は之等有機弗素化合物の應用飞百及した。脂肪族炭化水 素の弗化物は $\mathrm{CF}_{2} \mathrm{Cl}_{2} \mathrm{CClF}_{2}-\mathrm{CClF}_{2}$ 等飞依て代表され Freon なる總括名で呼ばれるるので寒剂の方面儿重視され他の侀せ持ち得 ざる無毒且不燃性なる特性を具一，又害蟲驅除化供する可能性も宁 り，一方劳香族弗化物は染料特にナフトール AS 染料に於て重要に して $\mathrm{C}_{6} \mathrm{H}_{5} \cdot \mathrm{CF}_{3}$ 及其誘造體のデアゾ化合物はナフトール AS 類の 下漬に依り種々なる色調を與一且其際 $\mathrm{CF}_{3}$ 基が光几對する㹂暒度 を揊すと同時に淺色的效果を示すてとを認めた。

更に弗素化合物研究に際して篇した 2,3 の興味ある觀察に就い ての記述をる行った。例一ば原料をる監化物製造の際反應速度を高

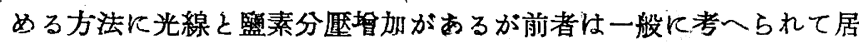
る程效果なき事を知つた。开メチル基の監素化並几弗素化の際力ル ボニル基及フタルイミド基以外は破燷される事 $\mathrm{CF}_{3}$ 基が直接ベン ジール核に附か好のの體系は比較的安定である事等をも認めた。 (Scherer, Angew. Chem., 1939, 52, 457) （里見 正）(永井)

4'-シアニン頻の㗪法 著者は 2-4' シアニン縮合に就てキナルデ ン・ヨードェチル化合物, キノリン・ヨードェチル代合物, 菏性ア ルカリの分子比を從來の $1: 2: 1.2$ を $1: 3: 3$ 《禁じて收量を $37 \%$ か

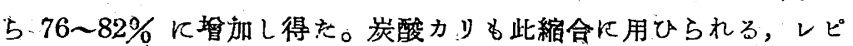
ギン・ヨードェチル化合物，2-ヨードキノリン・ヨードェチル化合 物，菏性アルカリに依て $60 \%$ 。收量の場合炭酸カリ又はトリェチ ルアミンを使用すれば 75〜77\% K筫加する。1ーメチルベンズチア ダール， ヨードアルキル化合物とキノリン・ヨードアルキル化合物 と絠合すると7〜13\%，のチアー4'ーシアニンを得るに過ぎ好が 4-シ アンキノリン・ヨードアルキル化合物を使用すれば 30 ー 37\% を得 るのは水素原子を一層反應性むるシアン基で置换した結果隹よる。 文 4ーシアンキノリン・ヨードメチル化合物はメチレン基を有する 梅素環式化合物之縮合する。例人壮 3-ェチル・ローダ ン及 2-ケ ト・デヒドロチオナフテンを縮合して夫ふ

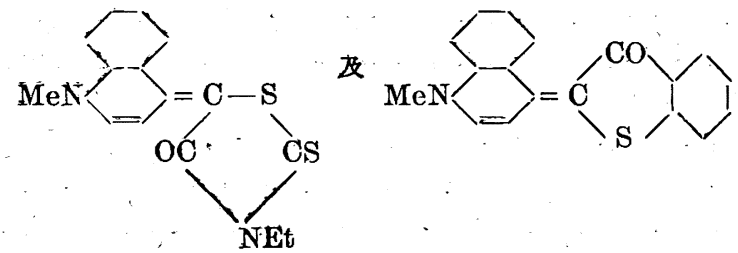

を得卡。2-シアンキノリン・ヨードメチル化合物はチアー2'シアニ シの生成に朋ひられる。然し收量の少いのは2-位置に比して反應 性の大なる 4-位置が縮合作用を妨げる篇でする。4-クロルキうリ ンそ沃化エチルと加熱すれば文獻にある如く單なるヨードェチル 化合物を造らず 4-ヨードキノリン・ヨードェチル化合物との混合 物を生ず。これはキナルヂン・ヨードェチル化合物と縮合してイン ンタニンを生成する。份純粹の4-クロル及4-ヨードキノリンのヨ 一ドメチル化合物，ヨードェチル化合物を製 Lた。(F.M. Hamer, J. Chem,Sic., 1939, 1008)

(溇网鉚)

ナイロンの染色 リサミンファスト染料及ソルウェー染料(ア ンスラキノン系酸性染料) 等の如き酸性羊毛染料は非毛の如く色染 する。リサミン染料は芟确及硫酸或は蟻酸と共に色染しソルウェー 染料は蟻酸又は醋酸酸性浴にて色染する。之等は日光及沙濯に對し

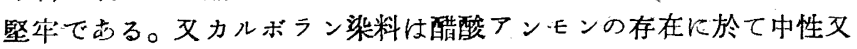
は弱アルカリ性浴にて色染し，クマシー染料は中性入は弱酸性浴に て色染する。兩者は沙濯試驗に優秀て絹の場合と同栐である。媒染 染料及びクロム染料はクロム後處理法に依るものが適當してるる が，クロム酸監は羊毛の場合よりも多量老必罚と寸る。直染染料に

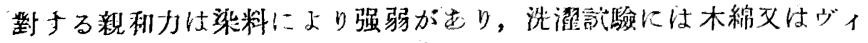

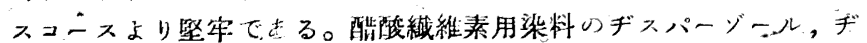

ュラノール,ソラセットの如きはナイロンの染色に適し, 前者 2 種 の染料は醋酸繊維素に色染したるるのと多少その色相を異にする。 後者の如き水溶性のものは儇秀なる吸收之均一性さ有する。之等の

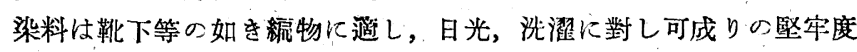
を得るには輕便である。監基性染料に䍌する吸收力は絹より劣るが 螢光を得るため利用せられる。建染染料及ソレドン染料等も染料 個々に上りナイロンに對する親和性を異にし，日光に對し强い堅 牢度を欲する場合に適當で支る。(G. S. J. White, J. Soc. Dyers \& Col., 1939, 55, 409) (松村義重) (线 周)

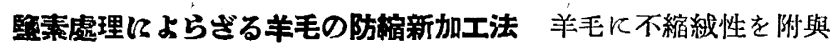
する方法は從來監素處理を似てしたが,近洔蒸留石油(White spirit) 飞溶解したる $\mathrm{SO}_{2} \mathrm{Cl}_{2}$ を以て加工する方法が發見された。著者は $\mathrm{SO}_{2} \mathrm{Cl}_{2}$ の濃度, 羊毛の重量に對する $\mathrm{SO}_{2} \mathrm{Cl}_{2}$ の夜量, 處理温度並

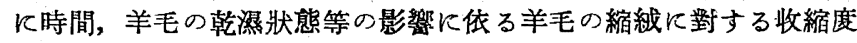
を检し合せて此加工による羊毛の强力，伸度並に羊毛織維の長さの 變化を無處理の子の子比校したるに，强力に於て $25 \%$, 仲度に於て

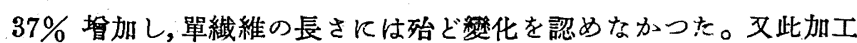
飞依り羊毛中の硫带量が $3.18 \%$ となり無處理の $3.06 \%$ ，校へて 著しく相違しない，欢に整素處理と此加工を夫々施行し羊毛の照素 及 $\mathrm{SO}_{2} \mathrm{Cl}_{2}$ の吸收度を湘定し且縮絊儿對する收縮度を比校した。 又雨加工羊毛の苛性シーダ溶液化對する溶解度を見た加盟素處理羊

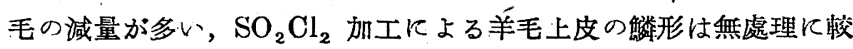

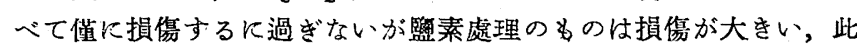

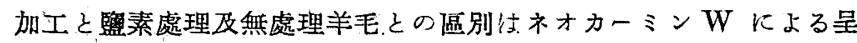

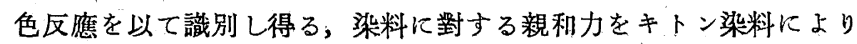
檢したるに冷浴染厄於ては無處理羊毛之監素處理羊毛とは同樣であ

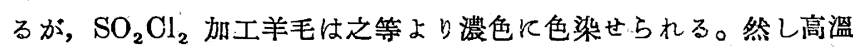

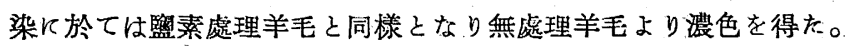
$\mathrm{SO}_{2} \mathrm{Cl}_{2}$ K代へると他の燕品を以て施行した，その内 $\mathrm{CrO}_{2} \mathrm{Cl}_{2}$ は 比較的他のものより効果があつたが $\mathrm{SO}_{2} \mathrm{Cl}_{2}$ とよる加工には及ば

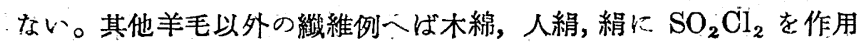
世し酸化銅アンモニアにて之等の流動度を無處理のものと比較测 定した。終りK $\mathrm{SO}_{2} \mathrm{Cl}_{2}$ 加工を大規模に施行するための諸條件並に 操作飞就て述べた。(A.J.Hall, J. Soc. D D ers \& Col., 1939, 55. 389)

（松村義重）(戗阔)

\section{4. 油脂, 蠟及石鹼}

酸敗の光學的研究，泒脂の安定度の測定方法乙して葉線素偠 (Chlorophyll value) の使用可能性に就て 油脂の酸敗は主と乙 て感䁷に低て行はれてわるが，信賴し得べき化學試驗法の必要なる は論を俟たない。今日過酸化物試驗，クライスス試驗等存在するも何 れも定性的筙圍を出でない。著者等な organoleptic rancidity $に$ 對して一層適合した定量的化學方法及酸敗の始まる前に於こ油脂の 安定度を指示すべき適切なる方法として葉綠素價を使用し得るこ とを提案した。此新方法は油脂の自働酸化がマグネシウム・クロ フィルの吸收比率に關保するてとに基いてみる。新魹なる油脂けて のクロロフィルを加へずして輝しい灰青色の螢光を與へるが酸敗に 接近せる油脂は甚しく此篮光を弱める。此繸化は連續的で抢つて之 を應大强化する方法としてマグネシウム・クロロフィルを使用す る。其方法としてけ 5 10 ce のるつぼに標準ク口ロフィル溶液 （螢光を發せざる鈸物油 $200 \mathrm{cc}$ にマグネシウム・クロロ・フィル 0.3 $\mathrm{g}$ を溶解したもの) を容れたものへビュレットより試驗せんとする 油を加一此油の色相を紫外線ランプの F 亿第2の標準液と比較す る。との第 2 の標淮液け各種の油に標準クロロフィル溶液をば滴下 せしめて丁度紫外緗ランプの下に試驗したとをに各々の油が中性色 を與へる迄加一をものでする。换言すれば標準油脂に對して更て1 滴のクロロフィル溶液が添加された場合に赤色。煀光を與一る其點 
まで加へたものである。此化學的試驗は油脂中に含まれてるる 天然 の成分に基き酸化の篇に除去されるものであつて, 酸化の結果とし て出來た新物質に依る反應ではない。此記驗简單であつて複雅な る操作なしに数分間で行ひ得る利點を有する。斯くしてクロロフィ ル價は organoleptic rancidicy が明嘹に現れる前に油脂の酸化を检 出する新しき信賴し得へき方法を提倛したものと考へる。(Mayne R. Coe, Oil and Soap, 1936, 16, 146) (岩井正昌)(上 野)

チクロペンチル・アルキルスルフォン酸の調製 ナフテンスルフォ ン酸と界面活性此較のたや值顉の末端にスルフネン基を有するシク ロペンチル・アルキルスルフネン酸及びシクロペンタン環に2 個の アルキル基を有する・シクロペンチルアルネル・スルフォン酸を合 成した。同じ側鎻の場合 5 佮環と 6 角環との相異を知るために Fencholäthylsulfonsäure ソーダ留及メンチルェチルスルフォン酸

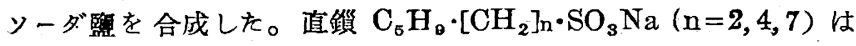

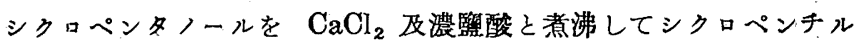
クロリド (87\%) とし其 Grignard 化合物にフォルムアルデヒドを 反應せしめてシクロペンチルカービノールとし, 更に監化物としス ルフォン酸ソーダを製した。

2 個の $-\mathrm{CH}_{2}$ 基の添加は Grignard 化合物にェチレンオキシド を反應せしぬ硫酸にて分解した。同栐にして 2-メンチル・エタノー ルをる製し $\mathrm{RMgBr}+\mathrm{CH}_{\mathrm{O}}-\mathrm{CH}_{2}=\mathrm{RCH}_{2} \cdot \mathrm{CH}_{2} \cdot \mathrm{O} \cdot \mathrm{MgBr}$.

3 個の $-\mathrm{CH}_{2}$ 基の添加には Grignard 化合物に $p$-トルオール

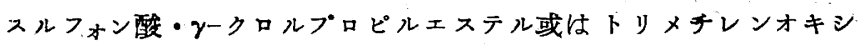
ドを縮合せしめた。， $\mathrm{C}_{3} \mathrm{H}_{7} \cdot \mathrm{C}_{6} \mathrm{H}_{7} \cdot\left(\mathrm{CH}_{3}\right) \cdot\left[\mathrm{CH}_{2}\right]_{\mathrm{n}} \cdot \mathrm{SO}_{3} \mathrm{Na}(\mathrm{n}=1$ 及 3) は Fenchon を荷性カリ液之 $240^{\circ}$ K加熱 Fencholsäure と しェチルェステルをアルコールK還元し $\mathrm{PCl}_{5}$ Kより監化物とし た。又 Fenchol-malonsäure 經由, Fencholessigsäure としェチ ルェステルをアルコールに還元, 盥化物とした。スルフォン酸ソー ダ整に相當する監化物或は臭化物を Strecker 反應により結晶亞硫 酸ソーダとオートクレーヴ中に加熱して製した。小さいアルキル基 をシクロペンタン環に持つシクロペンタン・アルキルスルフォン酸

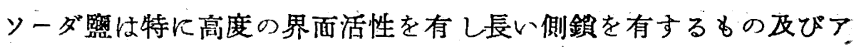
ルキル化シクロへキサン誘導體よ上優る。(S. Pilat und N. Turkiewicz, $B ., 1939,72,1527$ )

(木村和三郎)

1.4-添加としてのコレステノンのスルフォン化 前報 $(A ., 1937$ ， 532, 67) に於てコレステノンを無水醋酸中にて硫酸 1 モれルて スルフォン化し殆ど定量的にコレステノン・スルフォン酸-(6) (II) を 得た。コレステノンのエノール醋化物 (I) 硫酸化すると $\mathrm{C}_{3}$ K $\mathrm{OH}, \mathrm{C}_{6}$ Kスルフォン基添加し僢時醋酸六分離し又 3-クロル・コレス タヂェン (III) 坴硫酸化すると瞬時に $\mathrm{HCl}$ を分離して何れもコレ
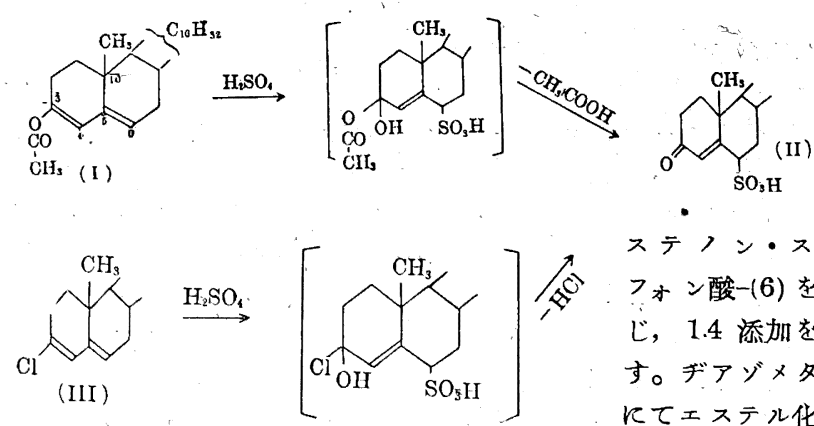

ステノン・スル

フォン酸-16) を生 じ, 1.4 添加を示 す。デアゾメタン にてェステル化す

るとェステルの

mp. $147 \sim 150^{\circ}$ でュレステノンの硫酸化によつて得圭スルフォン酸 と全く同一匹おる, (E. Kuhr, $B$, 1939, 72, 929)

（木村利三郎）

コレステノン・スルフォン酸ナトリウム監の當量傳導度 コレス テノン・スルフォン覆ソーダ分子は一端に水素化環式系と結合する 眯水性炭化水素長鋇を他の一端次は親水性ヶト基とスルフォン酸基
を有する代表的石畧構造を持つ。水溶液の膠質性を明かにするため 0.500 0 00302- $N$ 水溶液の當量傳導度を 測定し, 當量傳導度涱度 曲線は浱度の增加 之共に先づ急降下し $0.02 \sim 0.04-N$ K於て極小點 を示し，0.2〜0.4 そ於て本坦部の極大を示し志後緩かに下降し Me

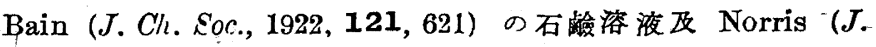
Chem. Soc., 1922, 121, 2161) のセチルスルフォン酸ソーダの場合 そ同一傾向を示す事を認めた。シレステノン・スルフォン酸ソーダ

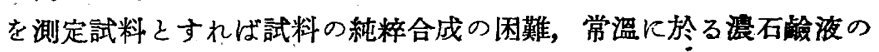
高粘度の困難等を除き得。

\begin{tabular}{|c|c|c|c|c|c|c|}
\hline $\begin{array}{c}N \\
\text { 當量/l }\end{array}$ & $\begin{array}{l}25 \mathrm{cc} \text { 中の } \\
\text { 酸量 (g) }\end{array}$ & 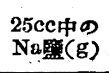 & $\begin{array}{l}t \\
{ }^{\circ} \mathrm{C}\end{array}$ & $\begin{array}{l}W \\
\Omega\end{array}$ & $\begin{array}{l}n=C / W \\
C=0.11737\end{array}$ & $\begin{array}{l}A=n / C \\
c=€ \Omega / R\end{array}$ \\
\hline 0.500 & 5.805 & 6.083 & 19.60 & 5.8 & 0.01271 & 0.02542 \\
\hline 0.300 & 3.483 & 3.650 & " & 9.3 & 0.007925 & 0.02642 \\
\hline 0.180 & 2.090 & 2.187 & $"$ & 16.7 & 0.004413 & 0.02452 \\
\hline 0.108 . & 1.254 & 1.316 & "I & 30.0 & 0.002457 & 0.02275 \\
\hline 0.0648 & 0.752 & 0.789 & " & 53.3 & 0.007383 & 0.02131 \\
\hline 0.0389 & 0.451 & 0.473 & " & 91.5 & 0.0008055 & 0.02071 \\
\hline 0.0233 & 0.271 & 0.283 & " & 149.8 & 0.0004920 & 0.02112 \\
\hline 0.0140 & 0.163 & 0.170 & "I & 231.5 & 0.0003184 & 0.03274 \\
\hline 0.00840 & 0.0978 & 0.102 & " & 304.5 & 0.0002420 & 0.02881 \\
\hline 0.00504 & 0.0587 & 0.0613 & "l. & 398.0 & 0.0001852 & 0.03674 \\
\hline \multirow[t]{2}{*}{0.00302} & 0.0352 & 0.0368 & " & 506.0 & 0.0001457 & 0.04823 \\
\hline & $\mathrm{H}_{2} \mathrm{O}$ & & 19.35 & 1100.0 & $7.10^{-6}$ & \\
\hline
\end{tabular}

(E. Kuhr, $B ., 1939,72,930$ )

(木村和三郎)

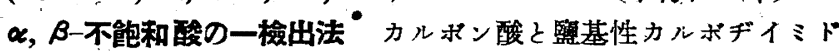

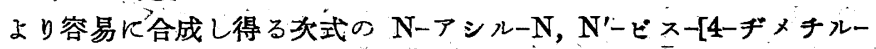
アミノーフェニル]尿素(本誌, 昭和 14, $42,72,73$ 態) は

$\mathrm{R}=-\mathrm{CH}: \mathrm{CH} \cdot \mathrm{R}^{\prime}$ 或は土 $-\mathrm{C} \equiv \mathrm{C}-\mathrm{R}^{\prime}$ ならば, 師ち酸基が $\alpha, \beta$ 一不館和酸な $\mathrm{OC}\left\langle\mathrm{N} \cdot \mathrm{C}_{6} \mathrm{H}_{4} \cdot \mathrm{N} \cdot\left(\mathrm{CH}_{3}\right)_{2}\right.$
$\mathrm{OC} \cdot \mathrm{C} \cdot \mathrm{C}_{6} \mathrm{H}_{4} \cdot \mathrm{N} \cdot\left(\mathrm{CH}_{3}\right)_{2}$ る時は着色するか或は着色を强めるととを發見した。此着色は酸基 加 $n-\alpha, \beta$-不館和酸 $\mathrm{RCH}: \mathrm{CH} \cdot \mathrm{CO}_{2} \mathrm{H}$ なる時最子强く $\beta$-置換に まり $\mathrm{RR}^{\prime} \cdot \mathrm{C}: \mathrm{CH} \cdot \mathrm{COOH}$ そなると弱くなり $\alpha$ 固换により $\mathrm{R} \cdot \mathrm{CH}: \mathrm{CR}^{\prime} \cdot \mathrm{COOH}$ となる時最も弱くなり發色の範图が狭くなる。 $\left(\alpha\right.$-效果)。文 $\alpha, \beta$-不能和酸儿於て發色はアクリ儿酸から $\mathbf{C}_{31}$ 酸 に至るまで炭素數の增加之共に弱くなり濃黃色から帶綠黃色之な る。プロピオール酸, テトロール酸の如さアセチレン酸, ソルビン

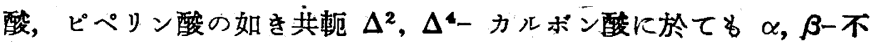
館和酸は氣色するがオレイン酸, リノール酸, リノレンン酸, シャ ウルムグラ酸誘導體の如きは着色しない。多數の實例につき操作及 適用範图メ゙示してもる。(F. Zetsch und G. Röttger, B., 1939, 72, 1599) (木村和三郎)

モ. Schmidt 等の「カルボ・ヂイミトによる動植物油の瞈酸」の 研究に就乙 E. Sch midt 等 $(B ., 1939,72,945)$ は種々の脂肪㞗 及ヒドロ芳香屬カルボヂイミド (E. Schmidt, F. Hitzler u. E. Lahde, $B ., 1938,71,1934)$ とよる動植物油の脫酸を研究しカルボ ヂイミド特にカルボ・デ・キクロへキシルイミド(I)により遊離裂は 油に難溶性ウレイドとして分離する事を認めた。著者等 $(B ., 1938$, 71,$1089 ; 1517 ; 2096 ; 1938,72,363$; 本誌, 昭 14, 42, 72; 73 參照）は先にカルボン酸どカルボデイミドは（1）カルボン酸 $1 モ$ ルのギイミド1モルへの添加にょり $\mathrm{N}$-アシ $x$ ・N， N'-ヂ置換尿素 の生成，(2)・カルボン酸，2モルとヂイミド1モルの反應による酸

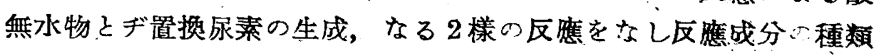
及び特に溫度, 溶劑が反應の方向を決定しカルボ・ヂー[4-ヂメチル アミノ・フェニルリーイミドはウレイドの生成に適するが葆酸乃至グル タル酸, フタル酸, 蟻酸等無水物化し易い酸主極めてウレイドを生 じ難きとと，(I) はカルボン酸無水物化の傾向强く脂肪酸との反應 成績體よりはウレイドを得ずして酸無水物及ギ置換㲾素を得を。本 研究に於ては過剩のイミド及酸の定量及 (I) とカルボン酸反應成續 體としてデチクロへキシル尿素 (II)（mp.829〜230 ）を分㒕して 
Schmidt 等が動植物油を（I）にて處理した時の難溶性析出物は脂 助酸ウレイドでなく難溶性の (II) であ.り脂肪酸はウレイド々して 析出除去されたのでなく單に無水物化したもので從て脫酸に必要 なる（I）の量は 1/2 モルなる事を指摘した。F. Zetzsch und (A. Fredrich, $B ., 1939,72,1477$ ) (木村和三郎)

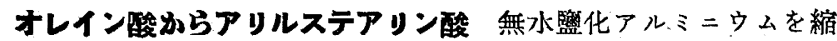
合媒としてオレイン酸より種々のアリルステアリン酸を合成，性狀 を研究した。

\begin{tabular}{|c|c|}
\hline 化 合 物 & $\begin{array}{lll}\text { 收 } & \text { 量 } \\
\text { 理 論 \% }\end{array}$ \\
\hline 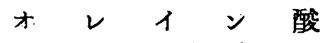 & \\
\hline フェニル・ステアリン酸 & $230 \sim 30(1 \mathrm{~mm})$ \\
\hline$p$-トワル・ステアリン酸 & $232 \sim 8\left(1^{\prime \prime \prime}\right) \underset{\left(232 \sim 8^{\circ}, 0.5 \mathrm{~mm}\right)}{38}$ \\
\hline キシリル・ステアリン酸 & $214 \sim 6(0.2 ") \underset{\left(235 \sim 6^{\circ}, 0.4 "\right)}{47}$ \\
\hline p・クロル・フェニル・ステフリン酸 & $217 \sim 23(0.2 ")_{\left(2 \div 0 \sim 5^{\circ}, 0.5 \prime\right)}^{25}$ \\
\hline pーブロム・" " & $241 \sim 50\left(0.2^{\prime \prime}\right) \quad 22$ \\
\hline$p$-メトオキシ・" " & $240 \sim 6(2 " \prime) \quad \underset{\left(246 \sim 8^{5}, 0.5 "\right)}{35}$ \\
\hline 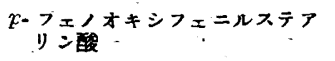 & 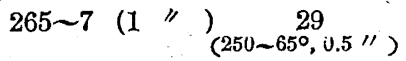 \\
\hline 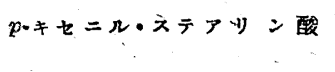 & $277 \sim 90 \quad 12$ \\
\hline トリル・ステァリン酸エチル & $220 \sim 2$ (1." ) $\frac{37}{\left(212-22^{\circ}, 1 "\right)}$ \\
\hline 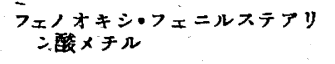 & $252 \sim 65(1 ")_{\left(253 \sim 66^{\circ}, 1 "\right)}^{44}$ \\
\hline
\end{tabular}

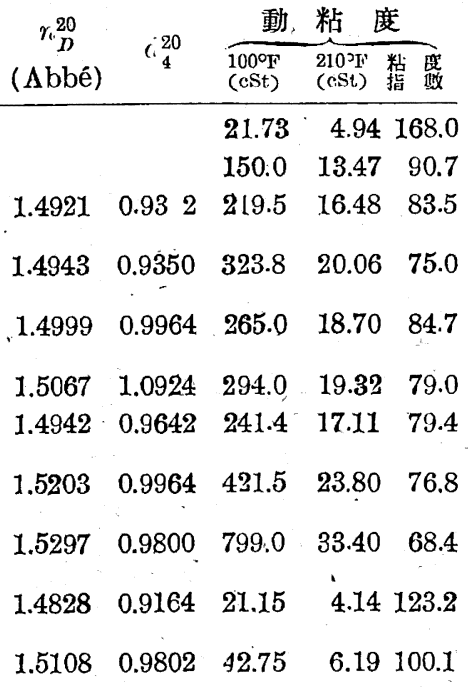

反應は芳香屬反倠成分の過剩を溶劑とし(1:7 壬ル比)或は $\mathrm{CS}_{2}$, 其 他の不活性溶劑中にて行ったが, 後者の場合には石油エーテル及0ギクロルベンゾールを用ひる時のみ反應成功し收量は低い。 $\mathrm{KMn}$ O4酸化火より相當する $p$ - 芳香屬酸を得て $p$-アリル・ステアリン酸 の生成を證し丈 Harmon 及 Marvel(J.A.C.S. 1932, 54, 2515) む り 9-10一異性體の生成を類推した。 $p$-クロルフェニルネテアリン酸 の $p$-置换フェナシルェステル mp. 室溫以下, $\mathrm{s} ・$ ベンジル・チウロ

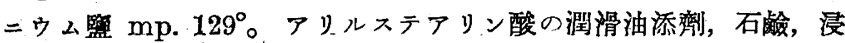

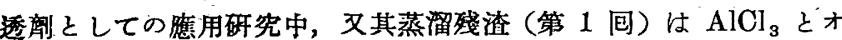
レイン酸の重合物なるへく滑油添淠として適當なるへし。動粘度は Ubbelohde の suspended-level-粘度計 (Ind.-Eng: Ch. Aral. Ed. 1937, 9, 85) Kよ り测定し又粘度指數は Hersh 等( Ind. Eng. Ch. 1935，27，1441）の表より求めた。（A. J. Stirton and R. F Peterson, Ind. Eng. Ch., 1939, 31, 856)（木村利三郎）

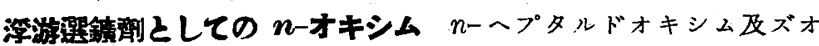

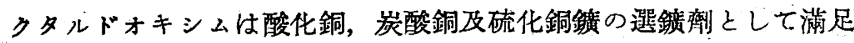
なることを認めた。低級オキシムは浮游選鈸劑として適しないが起 泡劑 (frothing agent) として又鐄潘沈着劑として共用し得。へプタ ルドオキシムは Bonsquet(Org. Synth., 1931，11，54)により又オ クタルドオキシム仙 H. Stephens ( $J . C h \mathrm{~cm}$. Soc., 1925, 127, 1874) により製した。(C. C. De Witt and F. von Batchelder, J. Am. Ch. Soc., 1939, 61,1250) (木村和三郎)

遇䌅抽出法几依る不战化物定量法の管易化 最近 1938 年 Wood 及 Roschen 兩氏は（Oil \& Soap, 15, No. 11, 287) グリース及牛 脂中の不畧化物の定量法に關して改良せる連續抽出法を發表した。 氏等は路化後濾過を容易ならしむるために $10 \%$ アルコールで洗临

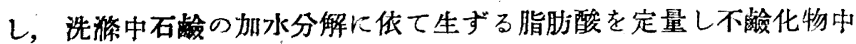
の脂助酸の補正を行つた。

著者等は更に筫駗操作の簡易を期するために 10\% アルコールて の洗淮の可否を额驗的飞比較檢討しWood 及 Roschen 雨氏の方 法の如く $10 \%$ アルコールによる洗波を行はず，脂肪酸の定量飞依

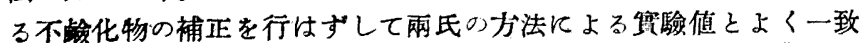

せる結果を得たと報告してるる（最高 $0.18 \%$ の設差）。郎ち著者の 定量法は Wood, Roschen 兩氏心方法を可成簡易化して, 定量に 要する時間を短縮したものでもる。郎ち不畧化物抽出後石油エーテ ルを含有したソックスレーのフラスコを蒸氣浴上に移し溶劑を除去 し續いて $101^{\circ} \mathrm{C}$ で 15 分間乾燥後冷却す。次に不銅化物を再び 50 $\mathrm{ml}$ の石油エーテルに溶かし一旦澏過す。此際澹紙の洗临に泩意を

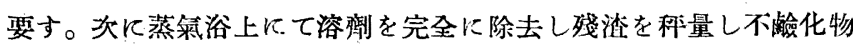
を算出す。（R. H. Rogers, Oil \& Soap, 1939, 16, 127)

(米勢千鶴男) (上 野)

メチルセルローズの石龄製造へ

の應用 メチルセルローズを充填 劑として硬質及軟質石鹼に配合す るときは石䀫の品位を落すととな く脂肪質を 30 ～32\% 節減すると そが可能である。メチルセルロー ズはつェネト繊維狀の乾燥固形物 であり 1〜11 lb に遏搾したもの で容易に引火せず，冷水に溶解し 無色 或は淡䜤色を是し渄㯖水中 では擬固する傾向があるが冷却す る之きは再び溶解する。又䒚品類 下對する抵抗性も强く，中性にし て $\mathrm{pH}$ には影繁を及ぼさない。 メチルセルローズの水溶液を混和 中の石鹼に 10２0\% 配合すると

李は石撂の起泡性を增加すると述 べてるる。 (Paul L. Smith, Am. Perfumer, 1939, 38, 3, 34-6; Oil \& Soap, 1939, 16, 144)

(米勢千鹤男) (上. 野)

\section{5. 精油，香料及化粧品}

Pycnanthemum lanceolatum Pursh の精油 本植物の䔈驗 的栽培の結果開花より得たる䊑油は 70〜 75\%の l-Menthone, 10〜 $15 \%$ の Pulegone (多分 d.) 及約 5\% のテルペンを含む。又全植 物よりの精油は 25〜30\%の $l$-Menthone, $45 \sim 50 \%$ の $d$-Pulegone 及 5〜7\% のテルペンを含むのであつて，l-Menthone は多分開花 中に合成されるるのと思はれる。本精油は齿磨用又はメント一ル製 造用飞用ひ得。( N. P. Kiry.alov, J. Appliel Chem., 1939, 12, 285; Chem. Abst., 1939, 33, 6526) (岡野一郎)

て-Citronellol Citronellol とゲラニオールとを同時に含む油を 液體 $\mathrm{NH}_{3}$ 中で $\mathrm{Na}$ を以て還元するに，ゲラニオールは不完全に 還元されて分離が困難であるが，此混合物を銅を以て脫水素を行子 とアルデヒドが生成されて蒸溜により分離可能となる。此方法を用 ひて Bourbon Geranium 油中ょり $l$-Citronellol $\left(\mathrm{Bp}_{10} 86 \sim 7^{\circ}\right.$, $d_{4}^{17}$ 0.854) を得， 之を $\mathrm{EtO}, \mathrm{MgCl}$ を以て還元して $l$-Citronellol $\left(\mathrm{Bp}_{10}\right.$ 108 $9^{\circ}, \quad[\alpha]_{\mathrm{n}}^{18}-2.15^{\circ}, \quad d_{4}^{18} 0.859, \quad n_{\mathrm{D}}^{18} 1.4576, \quad \gamma_{17} 29.2$ dynes/cm, parachor 計算值 4.29 , 俔測値 422 等) を紎粹飞得た。 Allophanate は融點 106〜 $7^{\circ}$ を示し， $d$-Citronello\}のそれと混融 するも何等融點降下を示さず。(Jean Doeuvre, Ccmpt.rend.1939, 208, 1658)

(岡野一郎)

相虂類果度よりの採油法 相㰌類の外皮を水々共に細破し常溫で ガス體である樣な溶劑特にブタンのやらなものと加医下に處理する と水の混つた混合液體が得られるから之を $0^{\circ}$ 以下に冷却して樹脂 狀の部分を除去精製し常法によりブタンを可收する方法であつて特 徵とする所は精油の收量が $90 \%$ に及び且ぺクチン等を含有し ない點でむる。(W. A. S.'Wright \& C. D. Barnes, A. P. 2,15 8,670 (1939); C., 1939, II, 1183)

(岡野一期)

Ocimum canum Sims の精油印度地方に產する灌木で „Mamri” 又は „Ram Talsi”等と呼ばれ約 $0.7 \%$ 收量で得られ 
る精油はラベンダー具を件つた强い特有のレモン臭を有しリナロー ル(10.9\%)，ゲラニオール及 Citronellol (7.3\%), Methylheptenon (2.4\%), Citral (60\%) 及 Citronellal (7.3\%) 等を含み，香料とし $\tau$ Citral の資源たり得る。(J. N. Tayal \& Sikhibhuson Dutt; Proc. Nat. Acad. Sci., India 1938, 8, 120; Chem. Abst., 1939, 33, 5952)

(岡野 一郎)

光學活性ピペリトンの分耀 ニーカリ油其他多數精油中に存在す るピペリトンは光學的活性度に於て純粹に分離されたととが無い。 英國特許 No. 5 8,001 はピペリトンを精油より分離すると際し凝固 點の甚だ低い溶劑を加へ又は加一ずして $-40^{\circ}$ 以下に冷却し諸成分 を含む精油から左旋性ピペリトンのみを析出させ滤過して集める事 を特徽としてるる。此方法に依ればラセミ型ピペリトンが存在する 場合でも唯液状に止るのみで活性體を容易に分離される。份二ーカ リ油よりの分離操作法 3 例を示してるる。(P.E.O.R., 1939, 30, 285)

(奥田 治)

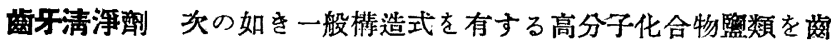
磨に添加するてとを主眼とする D.R.P. 675,837（權者 I. G. Farbenindustrie) である。

$$
\mathrm{R} \cdot \mathrm{CO}-\mathrm{N} / \begin{array}{ll}
\text { Alkylen- } \mathrm{X} & \text { 構造中 } \mathrm{R} \cdot \mathrm{CO}-\text { は } \mathrm{C}_{8} \text { 以上の高級脂肪 } \\
\mathrm{R}_{1} & \text { 酸のアチル基, } \mathrm{R}_{1} \text { は } \mathrm{I} \text { ケの水素乃至 } \\
\text { アルキル基, } \mathrm{X} \text { は }-\mathrm{SO}_{3} \mathrm{H},-\mathrm{COOH}
\end{array}
$$

或は $-\mathrm{O} \cdot \mathrm{SO}_{3} \mathrm{H}$ を示す。斯樣な化合物は反應性に富む高分子脂肪 酸誘導體とアミノアルキルースルフォン酸又はカルボン酸, 或はオキ シアルキルアミンの硫酸エスデルとの縮合物のアルカリ，カルシウ ム，マグネシウム，アンモ二ウム監類であり，齒刷子によりて良く 發泡し夙牙間䏚の不潔物を除去し，睡液により侵されるこるなく且

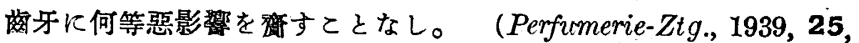
254)

$$
\text { （奧田治） }
$$

Verbenol, Myrtenol, Pinocarveol 並々其酸化誯迩體 Ver benol (I) は Verbena 油中に, Myrtenol (II) は Myrtus communis L. の精油中に, Pinocarveol (III) は Eucalyptus globulus L. の精油中に存在する事を記し各アルコールの分離方法並に物理 恒數を示してるる。之等アルコールの酸化生成物郎ち Verbenone (IV́) 及 Myrtenal (V) は接觸㧓の存在下に $\alpha$-Pinene を空氣によ り或は $\mathrm{SeO}_{2}$ とより酸化して得られ, Pinocarvone (VI) は $\beta$ Pinene の $\mathrm{SeO}_{2}$ による酸化に依て得られる。

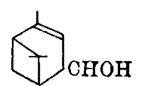

(I)

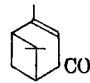

(IV)

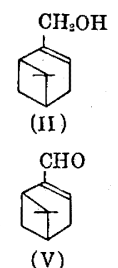

(V)

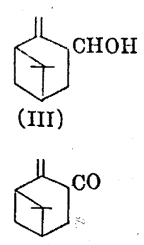

(VI)
（IV）は接觸還元により Verbanone (VII) そなり鐄酸を以て處 理すれば $\Delta^{3}-o$-Menthenone-5 (VIII) を生じ，之を再び接觸還元 に附せば $o$-Menthanone-5 (IX) を生成する。 (VI) 子亦接觸還 元を行へばヒソップ精油の主成分. Pinocamphone (X) を生ずる。

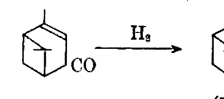

(VII)

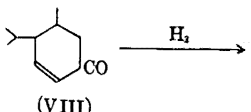

(VIII)

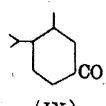

(IX)

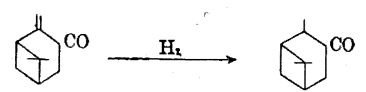

(x)

$\alpha$ 及 $\beta$-Pinene より合成される之等化合物は何れも传快なる香 氣を有し香料として將來興味志る物質である。 (Y. Mayor, Parfumerie Moderne, 1939, 33, 291)

(奥田
治)

\section{7. 顔料，塗料及樹脂}

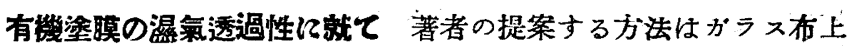

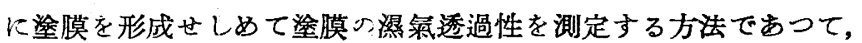
New York Production Club の裝置及操作と同法はパーチメント 紙“Patapar”上に塗膜を形成せしめる點をガラ久布に依つを點を 異にする。Patapar 及ガラス布上に塗膜を形成せしめたものの斷 面を揣大して撮影し其構造に依り優劣を論じ，雨者上に 4 種の空氣

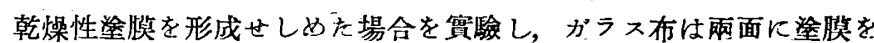
形成せしめ得 (Patapar は 1 面のみ可能), 又 Patapar では燒付 は不可能であるが，ガラス布は可能であり，乙の方法に依り蛙付條 件の決定を行ふに適し，ガラス板（スライドグラス）及ガラス布上 に塗膜を形成せしめて水吸收の測定を行つた結果は一致し，侣燒付 塗を行つてその塗膜の耐アルコール性を試驗した。結論としてガ ス布は蒸氣吸收及透過性の試驗に於る下地材料として好適であるて とを示した。(H. F. Payne, Ind. Eng. Chem., An. Ed., 1939, $11,8,453)$ (石橋 正樹)

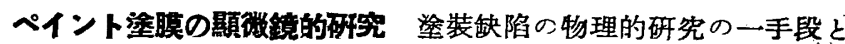
して，顯微鏡を用ふるととが便利である。先ゔ 10 倍位の倍率の低 い場合に調查し，更に倍率を上げて檢查を行ふ。廎料粒子の大いさ は本均直徑 $0.5 \mu$ 前後であるから試瞼㓐膜片の厚さは $10 \mu$ 位で十 分である。包埋劑としてはパラフィンより木舆が良く包埋劑として 必要な性狀は（1）酸價極めて小なるてと，（2）燃融點低きとと， （3）研磨及靤出しK依る良好な表面を作ること等である。合成樹 脂 $\mathrm{AW} 2$ と合成殓 $\mathrm{O}$ の混合物 (1:1) の子の良好, 白色の截片K

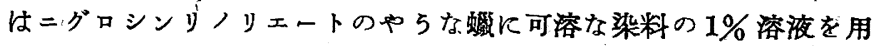
ふる。數回塗の老化した塗膜に就ては各塗首の境界に明確な黑い線 が見える。之を Grim-layer と名付ける。文銅䠞板上の塗膜に就て ミルスケールの下に錆が援つて塗膜缺陷を起したものをも检鏡に依

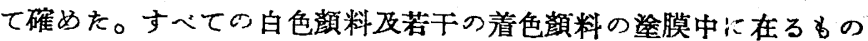
に就て顯微化學的試驗を行ひ其檢出に成功した。此方法は頑料の種 類を知るばかりでなく各症膜曆に於ける此等の頻料の分布狀㮩を知 るととが出來る便宜がある。(A. D. Whitehead Oil, Col. Chem. Assoc., 1939, XXII, 228, 139) (石橋 正樹)

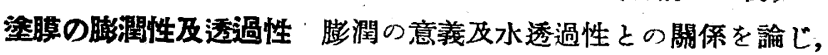
膨润にはミセル間のものとミセル內のものとがありり，此等の膨潤の

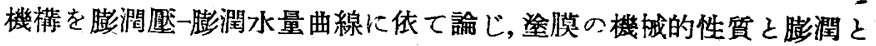
の關係をも論じた。更に著者の賽驗として, 亞麻仁油皮膜, スタン ド油皮膜の厚さと膨潤との關保, 油の前處理との關俰を混合割合の 異つたスタンド油，亞梳仁油混合物及粘度を異にしたボィル油皮 膜に就て, 膨潤度々 Erichsen 試驗機に依て叙膜の老化度を湘つた

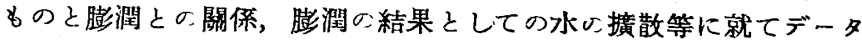
を舉げて論究した。 (A. V. Blom, J. of Oil Col. Chem. Asscc., 1939, XXII, 227, 104) (石橋 正樹)

紺靑のブロンジング (金屈光㵋) に影繁する諸條件 ( $\left.\mathrm{NH}_{4}\right)_{2} \mathrm{SO}_{4}$ そ $\mathrm{No}_{4} \mathrm{Fe}(\mathrm{CN})_{6} \cdot 12 \mathrm{H}_{2} \mathrm{O}$ との $60^{\circ} \mathrm{C}$ 水溶液に $\mathrm{FeSO}_{4} \cdot 7 \mathrm{H}_{2} \mathrm{O}$ の 60 ${ }^{\circ} \mathrm{C}$ 溶液を加一, $\mathrm{H}_{2} \mathrm{SO}_{4}$ と $\mathrm{NaClO}_{3}$ で酸化してて絊青を造る行程に 於て䫈料の金屬光澤に及ほす諸影䅞を試驗した。1）溫度 $25 \sim 30^{\circ} \mathrm{C}$ で酸化したものは最も少なく, 高溫て酸化したのは着色力大。2) 硫酸アンモンの黃血ソーダに對するモル比が $1: 2$ の時高溫酸化で は僅に光澤と着色力を減じ, 低溫酸化では $3: 2$ の時に最大の着色 力を示す。硫酸アンモンの代りにアミン類を使用する時, 脂肪屬化 合物は一般に芳香族化合物よりも金風光澤大，ウレアのみは金啳光

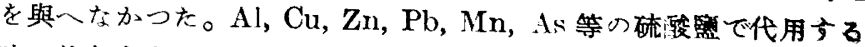

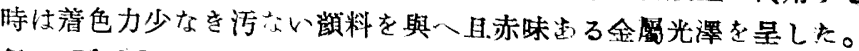

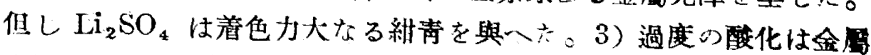

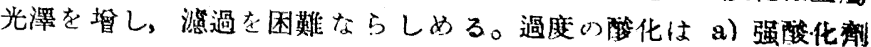

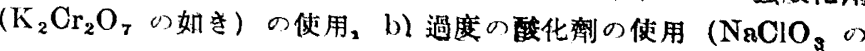


黃血ソーダに對する適當なモル比は $(0.25 / 1 \sim 1 / 1) ， c ）$ 酸化劑の急速 なる添加等によつて起る。4) 稀溶液加ら沈澱せしめると粒子の細 か、類料が得られる。5) 硫酸鐵液へ黃血ソーダを加へると粒狀, 金屬光澤及着色力少な 頑料が得られる。6） pH の小なる液中で 沈溊且酸化したるものは金屬光澤を與へ， $\mathrm{pH} 5.5$ で沈溊せしめを ものは最も金履光澤が少ない。7）乾燥の條件は着色力, 吸油量, 金屬光澤及硬さに影響を及ぼす。比瀑度 $50 \% 65^{\circ} \mathrm{C}$ が最適の乾嬠 條件であつた。8）X-光線に依て試驗しても，金屬光澤を有するも のと有しないるのと.の間に差別は認め難かつた。(G. C. Williams \& N. W. Muller, Paint Var. Prod. Main., 1939, 19, 240, 256)

\section{(松本 十九)}

新らしい合成乾燥性油 ヒマシ油から脫水反應により新乾性油デ エノル及支那桐油代用油トリェノルが合成された。其方法及性狀は 次ぎの如くである。

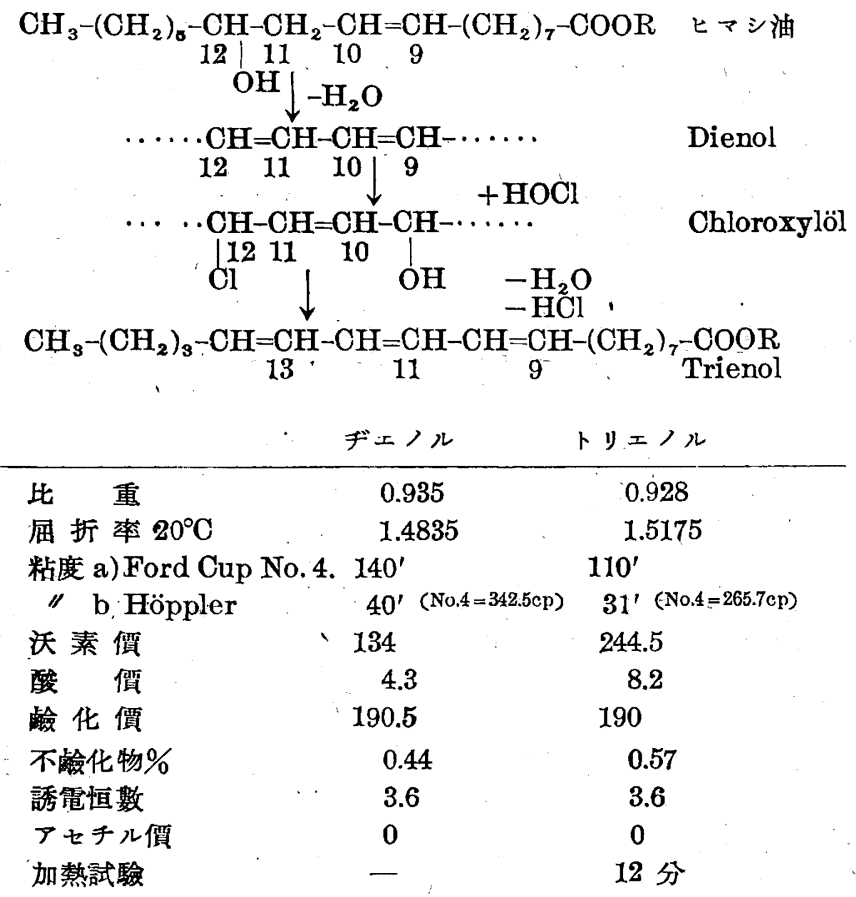

日光及紫外線照射によるイソメチル化の速度は桐油の方がトリエ ノルよりも早く;洤膜のしわ生成はトリェノルの方が少なく,ガステ ストによるしわの生成は兩者に大差なかつた。(Blom, A. V. Far ben-Ztg., 1939, 44, 901)

（松本十九）

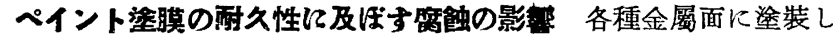

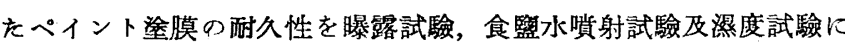
より制定し夫々儤露試驗-食監水貲射試驗，儤露試驗-潑度試驗の相 互關係を諭じ。耐久性は懪露する場所に於ける被塗面の磨飿性に

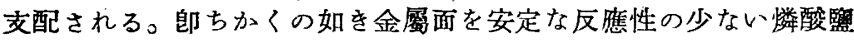
被膜にするゃ5化學處理（ボンデライト法）を行子々塗膜の耐久性

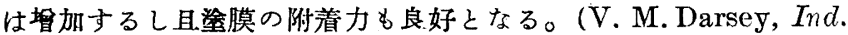
Eng. Chem., 1938, 30, 1147) (稻垣 英吉)

硝化綿ラッカー用溶留の評価法 前報 (Ir d. Eng. Chem., 1939,

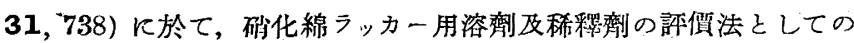
定粘度法之其應用に就て詳細に論じたが，それに引續き本報に於て は，現在使用されてるる多くのェステル類郎ち， ethyl acetate, ethyl propionate, isobutyl acetate, $n$-butyl acetate, isobutyl propionate, pentacetate を此方法で評價した。上記ェステル溶劑 はすへて市販の物の品位に近い物とし各種溶劑一の絛化綿溶液の粘 度を測定し，何各種溶劑をトルオールで種々の割合に稀襎した場合 の啸化綿溶液の粘度を測定した。其粘度は赛際の吹附作業に適當と

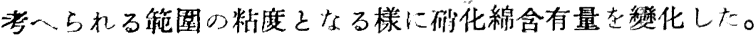

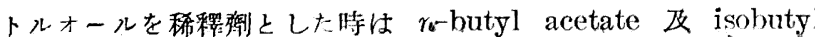

acetate は本質的飞同一の硝化綿飞對する溶解性を示し， ethyl propionate は ethyl acetate そ butyl acetates との間にめつて 确化綿に對して腙れえ溶劑としての性質を示してるる。 iso-butyl propionate の溶解力には isobutanol の含有量の影得が大きい。

さて以上の結果より所望の粘度に於る種々の比の溶劑一稀釋劑混 合物の溶解力を迅速飞計算し得る。 (V. W. W are and W. O. Teeter, Ind. Eng. Chem., 1939, 31, 1118)

（古關 靖夫）(踰 木)

岸化水素溶劑中の石㞸酸頻の定量 此研究は等料用石油溶劑中の 微量石炭酸類の定量を目的とし, 試料を $0.2 \mathrm{~N} \mathrm{KOH}$ 水溶液を以 て數司抽出し(通常 5 回の抽出で充分である), 各抽出液は $0.2 \mathrm{~N}$ $\mathrm{H}_{2} \mathrm{SO}_{4}$ 水溶液にて中和したる後, 水醋酸を加一, 各 6 滴宛の濃硫 酸及濃䂤酸を加へて 5 30 分閒蒸氣浴上に加熱して充分着色(次黃 色）世しめる。氷にて冷却したる後，濃アンモニア水を以て泩意深 くアルカリ性となし(この時色は濃くなる)，之を比色計に入れて標 準を比校して石炭酸類含有量を決定する。

標準は實際の試料からは種々の濃さ及色相の黃色が得られるが （之は存在する石炭酸の種類に依て定る）唯 2 種を用ひる。郎ち石 炭酸を用ひて帶綠黃色の標準色を得， $p$-tert-butyl phenol を用ひ て橙黄色の標準色を得る。本法は大體 $1 / 10,000 １ / 100,000$ 位の石 炭酸類を定量するの亿適するすのである。(Ind. Eng. Chem. Anal. Ed., 1939, 11, 438)

(古關 靖夫) (鉿 木)

\section{9. 繊維素，紙及セルロイド}

リグニンに關する研究 $(\mathrm{XX})$ 一リグニンに於るフォルムアルデヒ ドの生成 酸化銅アンモニア法りグ:ンから暴に（本誌 $42,46 \mathrm{~A}$ 態） $3.2 \%$ の $\mathrm{H} \cdot \mathrm{CHO}$ を得たが木材から $0.9 \%$ を得た事から此 值は木材中のリグニン量に正確に相當してるる故 H・CHO はリグ ニンから發生したものと考いられる。成因に就ては糖類によるとす るもの又脂肪屬側鑟に由來するとするもの等があるが，監酸性ア= リンと依て芳香屬メチレンヂオキシ基 (I) が $\mathrm{H} \cdot \mathrm{CHO}$ 子同栐にア クリダンを生成する事に依り著者等はリグニン中に (I) の存在を再 び强調した。硝化に際して此基の一部は破媛するが杂氣中で行子時 は更に甚しい故, Kürschner が斯樣なりグニンに就てピペロニル 基の存在を否定しても警くに足らない（本誌 $42,46 \mathrm{~A}$ 參照）。木 材とリグニンとはアニリン法及鑛酸蒸溜に對し同樣の行動を取るが 炭水化物は然らず。更にリダニンと(I) との類似性はアンモ二ア性 カリ溶液に於て示される。結局 Verbinlungsgewicht 178 を單位 そして 8 單位に 2 墭の (I) が洘へられ，殘りの 5 單位は $\mathrm{OCH}_{3}$ 1 箇， 1 單位が $\mathrm{OCH}_{3} 2$ 箇を有するものとされる。ブナリグニン ではその 50〜70\% がブレンッカテキンで 30 〜 50\% がピロガロー ル系のもので磨检リグニンでは前者が 90 文は $95 \%$ К後者が 10 又 は 5\%であら5。グアヤシル基の大部分と恐らくはピペロニル基 の全部は更に炭素を結合して橓接核の側顉こ縮合し，其度合はブナ の方が涂程進んで居るらしい。然しピペロニル基を持つ分解物がり グニンから如何にしても單襍されないのて束端に立つ(I) の存在は 疑問となつた。(K. Freudenberg, F. Klinck, E. Flickin jer u. A. Sobek, Ber., 1939, 72, 217) （上代 昌）

蒸解研究 (II) チオグリコー心酸と唐檑 リダニンとの反鷹 此反 應をHolmberg は亞硫酸とリグニンとい反應と同じもので出ると し, Hägglund 及 Freudenberg 等に依れば其際リグニン中にフェ ノール性水酸基が出現する。著者等はりグニンが比較的溫和な保件 でチオグリコール酸 (I) 几溶解する事かり特水水酸基に泩意して研

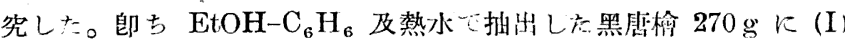
$150 \mathrm{~g}$ と $2 \mathrm{~N}$ 祭酸 $1.5 l$ と老加一湯煎上に 7 時間加熱してチォグ リコール酸リグニン $\mathrm{C}_{42} \mathrm{H}_{32} \mathrm{O}_{6}\left(\mathrm{OCH}_{3}\right)_{5}(\mathrm{OH})_{5}\left(\mathrm{HSCH}_{2} \mathrm{COOH}\right)_{4}$ (II) を得, Holmberg 亿依れば此中の!I)のカルボキシル基は遊離 して居る笘である故デアジメタンでメチル化され，そのエステルは 
襝化される管である。事實炭酸りーダで溫和に襝化され且其際 (I)の 一部もはなれ $\mathrm{C}_{42} \mathrm{H}_{32} \mathrm{O}_{6}\left(\mathrm{OCH}_{3}\right)_{6}(\mathrm{OH})_{4}\left(\mathrm{HSCH}_{2} \mathrm{COOH}\right)_{2}$ となり，

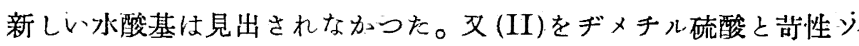
一ダとでメチル化すると矢張り(I)が分離した ${ }^{\circ}\left(\mathrm{OCH}_{3} 30.4 \%, \mathrm{~S}\right.$ $2.95 \%)$ (II) のフロログルチン呈色反應はリグニン中心水酸基に依 るものでメチル化すれば此反應は示さなくなる。リグニンスルフォ ン酸はフェノールとフェノールリグニンスルフォン酸を生成するが同 樣にして(II)\&フェ ールと反應し，グリコール酸の中 2 箇が 2 箇 のフェノールて置換される。 (C. E. Ahlein u. F. E. Brauns, $J$. Amer. Chem. Soc., 1939, 61, 277)

（上代 昌）

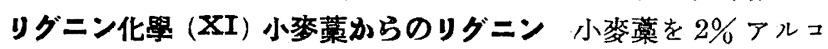

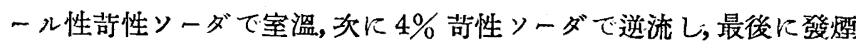
監酸で處理し, 3 種のリグニンを得。第 1 部は $\mathrm{C}_{38} \mathrm{H}_{31} \mathrm{O}_{7}\left(\mathrm{OCH}_{3}\right)_{4}$. $(\mathrm{OH})_{5}$ に相當し, 水酸基中 3 筒はヂアジメタンでメチル化される 故之はフェノールメはェノール性であら5。アルカリ熔融に依てり グニン重量の $4.5 \%$ 飞相當するプロトカテキュ酸が得られる。第 2 部 は $\mathrm{C}_{40} \mathrm{H}_{42} \mathrm{O}_{18}$ Kなり，恐らく $\mathrm{OCH}_{3} 4$ 筒， $\mathrm{OH} 4$ 筒を有す。第 3 部は第1部のものと同量の $\mathrm{OCH}_{3}$ を有するが炭素量が他の 2 者 より高い。(M. Phillips u. J. M. Goss, J. biol. Chem., 1938, 123, 241；Papier-Fabr., 1939, 37, Auszüge. 97) (上代 昌)

工業リダニン中の樹脂の組成 松柏類碎木パルプの酸處理かる得 られた 5 種のリグニンを數種の溶劑 $\left(\mathrm{CH}_{2} \mathrm{Cl}-\mathrm{CH}_{2} \mathrm{Cl}\right.$ が最良)に依て 樅リグニンに對して 9〜10\% の樹脂分を得た。之は亞硫酸パルプ のものと同じ組成を有す。(V. S. Kaminskii, S. L. Lyudmirskii u. A. A. Suetinov, J. applied Chem. (U.S.S.R.), 1938, 11, 1636; Chem. Abst., 1939, 33, 5651)

（上代 昌）

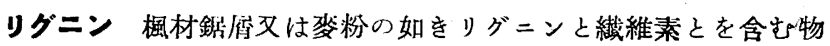
質を粉碎し，7～10 倍量の $0.4 〜 5 \%$ 硫酸を加一，165 280 ，90 $1,000 \mathrm{lbs} / \mathrm{in}^{2}, 2 \sim 5$ 分閒處理し; 直ちに常埾にしてリグニンを製 出する。(E. T. Olson, R. Katzen u. R. H. Plow [Northwood Chemical Co.] U.S.P. 2,156,159, Apr. 25; Chem. Abst., 1939, 33, 6045)

天然リダニン (I) 單離とメチル化（本誌 $42,146 \mathrm{~A}$ 參照）天然 リグニンは溶桇が結合する事もなく, 變化させる事もしないで單離 されたりグニンを指す。黑磨檜（100〜150 メッシュ）を冷水とェー テルで抽出後，96\%ェタノールで色の着かなくなる迄（3〜4日間） 室溫でリがーンを抽出し, 溶媒を除を, 水洗後エーテルで樹脂分を 除くと得られる。 $\mathrm{OCH}_{3}$ は $14.8 \%$ で嘪驗式は $\mathrm{C}_{41} \mathrm{H}_{32} \mathrm{O}_{6}\left(\mathrm{OCH}_{3}\right)_{4}$ ・ $(\mathrm{OH})_{4} \cdot \mathrm{CO}$ 文は $\mathrm{C}_{41} \mathrm{H}_{31} \mathrm{O}_{6}\left(\mathrm{OCH}_{3}\right)_{4}(\mathrm{OH})_{4} \cdot \mathrm{C} \cdot \mathrm{OH}$ となる。デア ゾメタンでメチル化すると $20.9 \% \mathrm{OCH}_{3}$ となり，更に $35 \%$ 郝性 ソーダとヂメチル硫酸と.でメチル化すると最後は $31.3 \% \mathrm{OCH}_{3}$ 迄 になる。之等すりグニン及其誘導體は他のリグニンに關する理諭 と全くよく一致する。(F. E. Brauns, J. Amer. Chem. Soc., 1939, 61, 2120)

（上代 昌）

リグニン及其關係化合物に關する研究 (第 41 報) 植物性物侗中

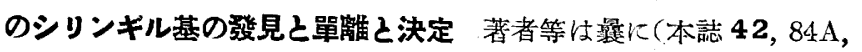
143A，144A，145A，190A）硬木リグニンは (I) と. (II) とが牛分宛 から成り，軟木リグニンは(II)を含まない事を報告した。唐榆りグ ニンは $\mathrm{OCH}_{3} \quad 15 \sim 17 \%$ (I は 15.8\%), 㼫リグニ ンは $\mathrm{OCH}_{\mathrm{s}} \quad 20 \sim 21.5 \%$

$$
\text { }
$$

$\left[\mathrm{I}+\mathrm{II}(1: 1)\right.$ では $\mathrm{OCH}_{3}$ $21.6 \%$ ] で理碖值とよく 合ふ。醋酸カリの無水工 タノール溶液を加一てシ

$$
-\mathrm{CO} \cdot \mathrm{CH}(\mathrm{OH}) \cdot \mathrm{CH}_{3}
$$

リンギル部を沈澱させる事に依てグアヤシル部との分離に成功し， エタノール, 楓リグニンに對して $53 \%$ のフェノール分(II) を收得し 得た。此等から得た結果を綜合すると硬木リグニンには (III) の存
在を考へると都合が良い。猶 (II) の合成法をも示した。<smiles>COC1CC(C(O)(CC(=O)O)C(C)CC(C)C)CCC1O</smiles>

(M. J. Hunter u. H. Hibbert, J. Amer. Chem. Soc., 1939, 61, 2190)

（上代 昌）

リグニン及其關係化合物に關ずる研究 (第 42 報) 重亞硫酸監に 可溶の抽出リダニンの單離 木材中にあるリグニンは重亞硫酸锚に 溶解するが酸の使用に依て抽出したりグニンは最早溶けない。アセ チル化した释材からら得たアセチルリグニンを加水分解して得られた yグニンは全 $\mathrm{SO}_{2} 6 \%$, 結合 $\mathrm{SO}_{2} \quad 1.4 \%$ の重亞硫酸整液に $110^{\circ}$ で 完全飞溶けた。郎ち赤懈材粉を $\mathrm{EtOH}-\mathrm{C}_{6} \mathrm{H}_{6}$, 熱水及 $5 \% \mathrm{NaOH}$ で抽出してから無水醋酸，承醋及濃硫酸に依て窒素氣流中で１5～ $30^{\circ}$ で醋化し, $20 \%$ 醋酸ソーダ中に注入して木枌醋化物を得, その クロロフォルム溶液加ら溶㩒を除定，アセチルリグニンをアセトン で抽出し，水中に注いで收得した $\left(\mathrm{OCH}_{3} 11.0 \%, \mathrm{COCH}_{3} 35.4 \%\right)$ 。 加水分解はアセトン溶液に $20 \%$ 当性ンーダを加一，アセトンを除 き水を加へて行ふ $\left(\mathrm{OCH}_{3}\right.$ 20.8\%)。悦てのリグニンはピリヂンと 無水醋酸, 次で無水醋酸, 水醋及湦硫酸でアセチル化すると再び醋 化され， $\mathrm{OCH}_{3} 16.8 \%, \mathrm{COCH}_{3} 22.9 \%$ となり，アセトン及デオキ

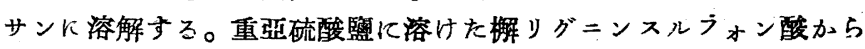
ワンリンとシリンガアルデヒドとが得られたが,果䌅, ヒドロキシフ ルフロール等から同條件で得たものは結晶性醋化物でリグニン樣物 質は得られなかつた故 Hilpert の說は支持されない。（W.H. Steeves u. H. Hibbert, J. Amer: Chem. Soc., 1939, 61, 2194)

\section{（上代 昌）}

\section{リグニン及其關係化合物に關する研究（第 43 報）リグニン構成} 物犋中のピベロニル基の缺如 Freudenbergはリグニンからフォル ムアルデヒド $(\mathrm{I})$ の生成を發見し，諸學者子認めて居るが，F 氏は それをピペロニル基に由來するるのと考へ，アクリダンの生成（体 誌 42, 46A，79A 參照)に依て確認した。著者等はリグニン抽出條件 ではピペロニル基は $25 \%$ しか分解せず，页沸嵱せる $95 \%$ 蟻酸で は 15\%しか分解しないのKリグニン中の(1)を發生する基は 90〜 $95 \%$ が分解する事を知つた。又若しか〉る基が存在するとすれば (II) の樣な構造を有つて居る筈であるが, てのものから(I)は發生し

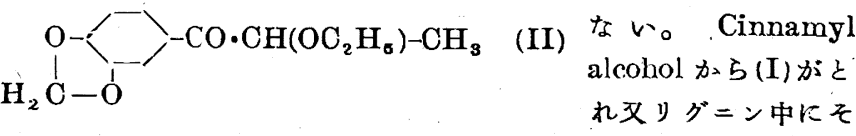
の存在は考へられる故リグニンから發生する(I) は芳香性側鑍中の 斯樣な基に由るのではなか.ららか。(M.J. Hunter u. H. Hibbert.
J. Amer. Chem. Soc., 1939, 61, 2196)
(上代 昌)

リグニン及其關係化合物に關する研究（第 44 報）相材のエタ， 一ル蒸解： 水溶性アルデヒド分の分離之磪認 前報(本誌 $42,80 \mathrm{~A}$ 參照）で唐檜及楓材の土タノール蒸解加ら水溶性芳香屬フェノール, 酸、アルデヒド双中性物質を得を事を報告したが，此處にそのアル デヒド分に就て報告す。其總計は Klason リグニンに對して $8.2 \%$ $\kappa$ 相當 $L$, Syringoylacetaldehyd (Syringyl-CO $\cdot \mathrm{CH}_{2} \cdot \mathrm{CHO}$ ) (I) (mp. 740. 74.5 ), Syringaldehyd (II) (mp. 110 111 ${ }^{\circ}$ ), Vanilloylacetaldehyd ₹ Vanillin 各が殆ど等量宛から成る。此時 シリンギル基とグアヤシル基々の分離は第 41 報の方法を改良し,

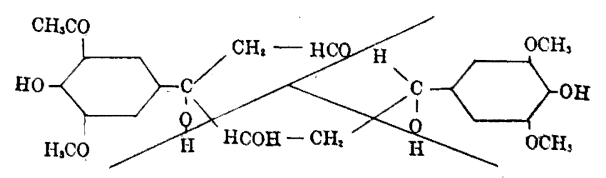

III

無水アンモニア,ェタノール溶液に依て前者を定量的に沈没させ え。前派 (本誌 $42,143 \mathrm{~A}$ ) にアルデヒドとフェンールとの樎合を 
假定したが(III)を假定する時は，圖の漛に切兴する時 (I) と (II) と を等量與へる。すると又゙(I) とフロログルチンとから代表的なアシ トチアニディン, Vanilloylacetaldehyd とフロログれチンとから 代表的なフラボンであるルテオリンの生成機棈が考へられる。(J. J. Pyie, L. Brickman u. H. Hibbert, J. Amir. Chem. Soc., 1939, 61, 2198)

（上代 昌）

リダニン及其關係化合物に關する研究（第 45 報）※-Hydroxyvanillone の合成之其性狱 唐檜と㑉とのエタノール蒸解加ら $\alpha$ Hydroxyvanillone（I）を單離じた事は前報した，が弦に其合成と性 狀飞就て報告す。

Veratrole $+\alpha$-Bromopropionyl bromide $\mathrm{AlCl}_{3}$

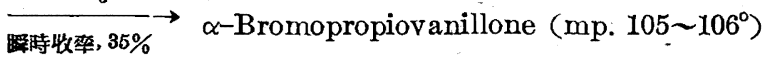

Q. Na-acetate+Acetic

anLydride, 收 $\overrightarrow{44 \%} \propto$-Acetonylpropiovanillone acetate

(mp. $\left.122 \sim 123^{\circ}\right)$

Alcobolic Kali

$$
\underset{\text { 收率 } 92 \%}{\rightarrow} \text { I }\left(\mathrm{mp} .109 \sim 110^{\circ}\right)
$$

(I)は2級アルコール性顯著, 活性水素は $p$-phenolic $\mathrm{OH}$ のため 理論値より低い。酸類に對してベンジインと同樣に反應し，アルカ

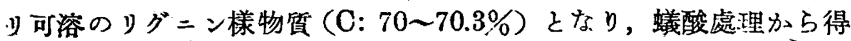

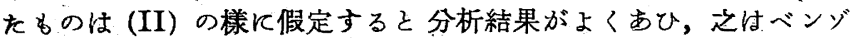
インとブレンッカテキンとから硫酸處理で得たフラン・トリマーと よく似てるる。<smiles></smiles>

(A. B. Cramer u. H. Hibbert, J. Amer. Chem. Soc., 1939, 61, 2204)

（上代昌）

\section{0. 糖類，澱粉及其他の㞸水化物}

酸化還元電位差の測定经依る還元糖の定量 此方法の必要性は電 尊度に依る灰分の定量と等しく，簡易で，磪䔈な點にある事仕明か である。Lane 及 Eynon 氏の方法は困難で速かでない。讀みの容 易な事はポテンショメーターに比べて比較にならない。Schaffer 及 William ·方法は (J. Biol. Chem., 1935, 111, 707) 葡萄糖飞探 用され，果糖には不磪赛であつたが，現在の操作に於ては此困難さ も征服され，果糖，轉化糖 及 蔗糖の存在に於る轉化糖の定量に 應 用されてるる。Schaffer 及 William の方法はフェリシャン化カリ 及フェロシャン化カリの存在に於て，砂糖溶液に浸した白金線の電 位差の測定にある。

用ひられた試苴は次の如きものである。

(1)

(2)

\begin{tabular}{|c|c|c|c|}
\hline 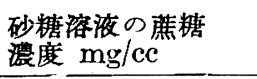 & $2.0 \sim 0.05$ & $0.05 \sim 0.001$ & $0.0025-0.0001$ \\
\hline \multicolumn{4}{|l|}{$\mathrm{g} / \mathrm{l}$} \\
\hline $\mathrm{K}_{\mathrm{g}} \mathrm{Fe}(\mathrm{CN})_{\mathrm{g}}$ & 29.6271 & 5.9254 & 0.2963 \\
\hline $\mathrm{K}_{4} \mathrm{Fe}(\mathrm{CN})_{6} \cdot 3 \mathrm{H}_{2} \mathrm{O}$ & 4.2233 & 0.8446 & $0.0+22$ \\
\hline $\mathrm{Na}_{2} \mathrm{CO}_{8}$ & 50.00 & 50.00 & 50.00 \\
\hline $\mathrm{NaHCO}_{3}$ & 10.00 & 10.00 & 10.00 \\
\hline $\mathrm{NaCl}$ & 117.00 & 117.00 & 117.00 \\
\hline
\end{tabular}

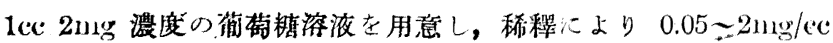

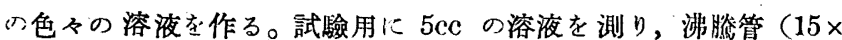
$2.5 \mathrm{~cm}) の$ 中に入れる。先ゔ等量の（1）の試藥を加へ，振澄してよ く混合する。第 2 の管に同量の試藥を入れ砂糖溶夜の代りに水を入 れる。兩方の管に清潔なゴム栓及毛細管を雨込み，加熱中の水分の 損失を防ぐ。次で此等を沸渗せる湯浴に 15 分間浸し流水にて冷却 し，凝縮する水を振って除き $25^{\circ} \mathrm{C}$ の恒溫槽に放置し, agar- $\mathrm{KCl}$ bridge に連結する。白金極を入れ，Cambridge-Cole 電位差計に 連結する。砂糖溶液は常飞負の粡荷を負ぶ。そして其電位差を電位 差計で䜠む。

此方法にて9’實驗を行つてるる。第 3 の䨘驗では果糖に低て 得た結果と，雱萄糖の結果と一致してるる。第 4 の賽驗に於ては 改良した方法を，轉化糖に見られる制合の術萄糖及果糖の混合物に 適用した。即ち

（a）純粹大䒔茷糖及果糖を使用して，(b) インヴェルターゼにより 蔍糖から作つえ轉化糖を用ひて，(c) Lane 及 Eynon 法化依り HCI の轉化に依て蔗糖汃ら作つた轉化糖を用ひて。

(a), (b), (c) の結果は大體接近した值を示してるる。筫驗 5 に於 ては蓔結の存在に依て，電位差を減ずる樣である。惯驗 6：蔗糖の 種々の䀼度に於て觀測した電位差及轉化糖の濃度との關保が表に示 してある。貸驗 7: 精製したシラップに就て, 電位差計と Lane 及 Fynon の方法との比較をしたが，其結果はよく一致してるる。筫 驗 8: Lane 及 Eynon の方法々電位差計の方法を, 粗汁, 閉波及 粗糖に用ひたが相當相違してるる。赛驗 9: 粗製品を試料とした

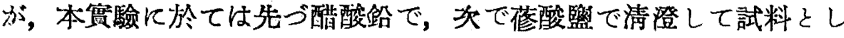
た。此清澄は Lane 及 Eynon の方法には殆ど影響を改ほさない が，電位差計法には非常に影㰷し， Lane 及 Eynon 法の結果と非 常によく一致してくる。

此清澄は不十分なものにも拘らず，大體一敌した結果を得る事か 出來るのは，本方法の䔈用化の可能性が十分あることを示してるる ものである。本方法が例へば Lane 及 Eynon 法の如く容量的方法 よりも，長くかかる样に思はれるか子知れないが，若し $80^{\circ}$ 及 $25^{\circ}$ C の浴を用意して置き，6－8 本の管を保持することが出來るなら ば，多くを試驗する場合其總時間恃非常に減ずる。又清澄はたぐ粗 製品にだけ必要なので屯る。(H. C. S. de Whalley, F. I. C., M. I. Chem. E., Int. Sugar $J ., 1939,41,312)$ (安倍通夫) (武 富)

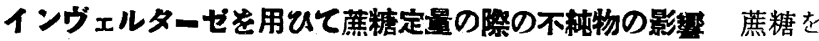
定量する種々の方法の中でも，インヴェルターゼを加水分解に用る る複旋光度の方法が最も正磪な栐である。然し 此方法はインヴェル

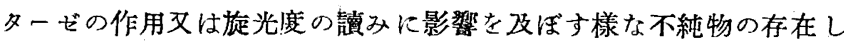
ない事を假定せ朴ばならぬ。此等の點の研究のために著者はPaine 及 Balch 氏の記載したものに從て, 複旋光度の方法を砂糖の試料

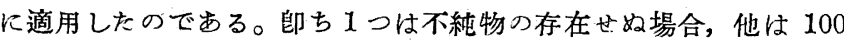
cc 中 $1 \sim 5 \mathrm{~g}$ の不純物の存在する場合飞就て實驗を行つた。其等の 結果から次の如く結論せられた。

(1) 粼酸アンモ二ウム，硫酸マグネシウム及蓔糖擸は惯際には

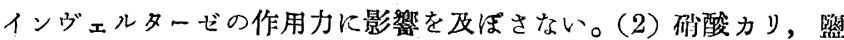

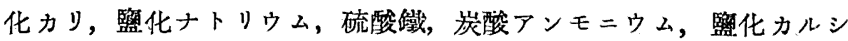
ウムはインヴェルターゼに依る蔗糖の轉化を阻害し, 其阻害の度は 硝酸カリが少く，上記の順に次第に大きくなる。(3) 硫酸カリ及壆 化カリは長く接觸するにつれ，蔗糖の加水分解に低て生ずる轉化糖 を破壤する。其還元は祭の高濃度に於て一層著しい。(F. A. Soliven \& A. U. Agdeppa, The Phillipine Agriculturist, 1938, 27, 43；Int. Sugar $J, 1939,41,276$ ) (安倍通夫)(武富)

砂糖及其誘筫體の利用 砂糖の利用法として，最もよく知られて るる方面では，食料品等の防腐劑，又還元劑として還元金屬䧣化物 の製造に，皮革の脫灰，支那セメントの製造等に用びられてるる。 その他，糖類から得られたェチルアル:ール及アセトアルデヒドよ りブタヂェンを合成し，更に重合に依て合成ゴムを造るととが出來 
る。1935 年以來, ロシアに於てはアルコールからの合成ゴム 20,000 $\mathrm{t}$ の)製造に成功し，良好なる收率を示してるる。蕂糖のエーテル類 中 octopropionate, octobutyrate, heptabenzoate, butyrate は色 々の生成物の製造に用ひられてるる。又アメリカに於ては Sucrose octoacetate が可塑性物質として用ひられてわる。Sliwinski (193t)

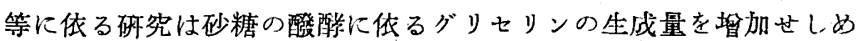
た。此醱酸によるグリセリン製造は歐洲大戰中ドイツで行はれたも のであるが，最近他の酸酸菌による其等の適當な條件が特䛨となつ てるる。蔗糖の砂化は第2次的に重要なものである。最近は Atlas Power Co. に於 $て$, 轉化糖の電氣的還元により 6 傊アルコ ールにするといふ新しい方法で Mannitol, Sorbitol の製些が工業 化されてるる。ソルビトールは觸媒例へばニッケル，コバルト，銅 及夫等の活性された酸化物の存在に於て，水素に依るグルコ一スの 還元に依て得られる。

ソルビトールは紙の製造, レザーの製造等に用ひられてわる。其 吸濨性は特別の顀值がある。可塑性物質方面に於ては F.M. Hesse

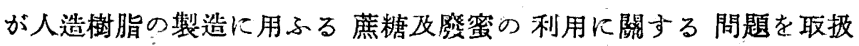
ひ，色々の名稱で廣く工業に用ひられてるる。此等の製品は凡て蓔 糖，莎萄糖，果糖几依て得る事肪出來る。

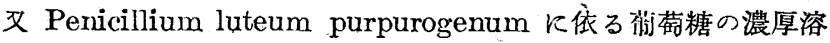

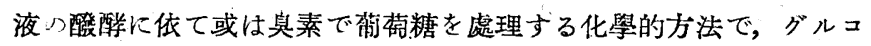
ン酸の盤類が得られ此等は祭藥に用ひられる。色ねの結合のグルニ ン酸も工業的應用のため, 市場に出てるる。

醭母方面に於ては以前はパン製造に用ひられた醉母はビール醉母 であつたが，之は廢蜜から作られる醉母に依て代られた。世界に於 ても設備の整つた工場では砂糖溶液から $48 \%$ の收率で, 優秀な醉 母が作られてるる。そして最近蛋白質が高いので猫, 孚牛, 馬等の 飼料つため, 廢蜜を醉母の製造に用ひてるる。周知の通り醭母は窒 素に富み，特に價值があるのは,ヴィタミン,アミノ酸，鐄物の辟を 含んでるる。窒素に富む酻母は人間の禁養になる。特にドイッでは スープ等に用ひられる。可望性物質も醭母から作られる。

以上述べた如く醉母は策盖になるので，缺藥への利用はよく知ら

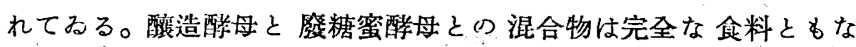
り，ヴィタミン B，ヴィタミンD K富み，他のヴィタミンをも多少

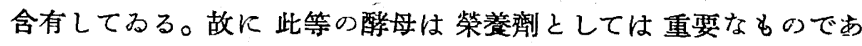
ろ。(G. Stampa, Int. Sugar J., 1939, 41, 270)

$$
\text { (安倍通夫) (武 筍) }
$$

\section{2. 製革及膠類}

\section{クロム辍腹の研究 (IX) 過剩グルコースのクロム液に及ぼす影}

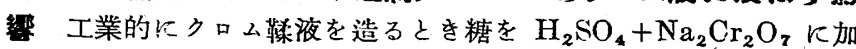
一る法 (a) そ $\mathrm{H}_{2} \mathrm{SO}_{4}$ を giucose $+\mathrm{Na}_{2} \mathrm{Cr}_{2} \mathrm{O}_{7}$ K加一る (b) 法飞 がある。(a) Кむりては最初加一られたグルコーズの液榈を强烈な 酸化劑が圍むと考へられる故反應は激烈で生成物は殆ど $\mathrm{CO}_{2}+$ $\mathrm{H}_{2} \mathrm{O}$ よりなる㤁，反應ひ後期には酸化劑の濃度が低下する故種な の有機物, 即古 formic, acetic, oxalic acids や未知糖分解物質が 出來る。(b)にありては反應は初期より (a) に比して烈しくないる 考入られる。著者は 14 種の (b) 法によるク口ム䩼液と 12 種の (a) 法に依るクロム鞢液を詳細に分析研究して次の結果を得た。

（1）過剩り糖が還元に用ひられた場合，(b) は（a）反比し糖の量 に依るクロム液の性質の戀化恃著しい。（2）ク口ム錯篮の外部に

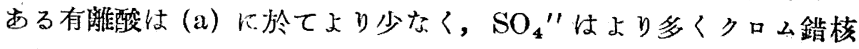
に侵入 (penetrate) してふる。(3) 生成有機酸の量は (a) が少な

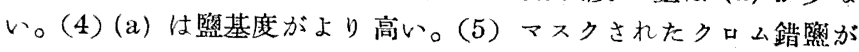

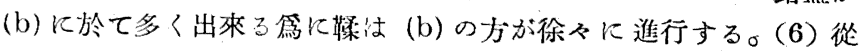
て革は軟かく銀面は繊細となり，白味の多、革が得られる。(E. R. Theis, J. 1. L. C. 1., 1939, 31, 397)

(田谷三郎)

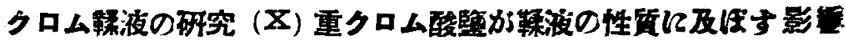

繁基度 $40 \%$ Kなる粶硫酸を重クロム酸ソーダ十糖に加一 $\mathrm{Cr}_{2} \mathrm{O}_{3}$ として 1\% 20\% に變へ夫影唩を研究した。結果は次の傾向を示 した。(1) 1 2.5\% $\mathrm{Cr}_{2} \mathrm{O}_{3}$ の濃度では䢱元は不完全である，25\% 以上より還元は完全々なる。（2） $2.5 \%$ より上の濃度では冷熱時 共監基度は (cold \& hot basicilies) 殆ど一定で hot basicity 算上上り $25 \%$ 低い。(3) 生成した苳酸, 挥發酸, 糖分解物質の量 は $\mathrm{Cr}_{2} \mathrm{O}_{3}$ の濃度と共に管加する。

以上の結果より鞣液の化學的性質を一定に保つ衣は重ク口ム酸睡 の、浱度を一定に保つ必要があり，濃度の晢加は葆酸を多く生成! 從 て (xalate ion“がクロム核中に浸入し中すい性質より oxalato化合物の篇飞䩮製作用が變化する事が考へられる。(F. R. Theis \& T. F. Jacoby, J.A.I.A.C., 1939, 34, 461) (田谷三郎)

比色法に依る Cr の定量 從來多くの $\mathrm{Cr}$ の比色定量け 6 傾の クロム麗で行はれたが，肉眼では黃色の僅少な差を識別する事は团

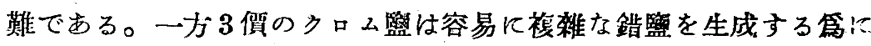
一空の組成を有せず比色法に探用出來なかつた。著者な落酸が極 めて安定な Trioxalatochromisäure を造る點より，過剩の葆酸々

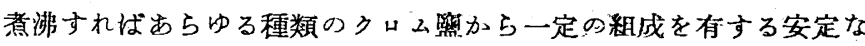
錯䜿が得られ，且此のオキザラ一トクロム錯監の溶液か：Lambert-Beer の法則飞從ふ事を確認せる事より, 此色計を用子れは

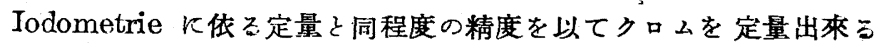
事を見出した。但しクロムの涱度が $2.5 \mathrm{~g} / l \sim 0.3 \mathrm{~g} / l$ の範圍でないと 精度が低下゙する。此方法に依れば未染色のクロム革の $\mathrm{Cr}$ 含有量を

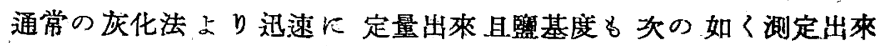
る。

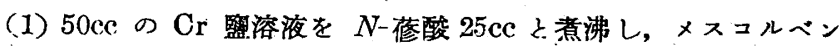
中下滤過して洗液を合し $100 \mathrm{cc}$ とす。比色法に依り $20 \mathrm{cc}$ のク 么量を $a$ とす。(2) 上記 $N$-苳酸を $N / 10-\mathrm{NaOH}$ 一滴定する $b c c$, (3)メスコルベン中ょり $20 \mathrm{cc}$ の $\mathrm{Cr}$ 液を取り N/10- $\mathrm{NaOH}$ で 觙定する, $c$ cc とせば

籃基度 $=(b-c) \times 0.173 / a$

にて表はさる。但し指示藥は Methylrot+Methylenblau 1:1 か 良好である。(E. Ueberbacher u. K. Th. Dröscher, Collegium, 1939, 832, 433)

（田谷三郎）

\section{通}

カリエ係數之粒狀性の關係 カリエ保數は寫蜑材料の粒狀性を测 定する手段てして用つられてるるが，むる人はカリェ保數を粒狀性 測定に使用し，むる人はカリエ俰數之粒狀性の間には何等關保はな いと云つてるる。著者は此問題に就さ多くの研㶢發表を綜合检討し た。抑々カリエ保數とは $\frac{D / 1}{D_{\sharp 4}}, D$ ，は平行光線に依る濃度，D\&は分 散光線による濃度で主る。粒狀性を $G$ とすれば

$$
G=10 \times \frac{D_{/}}{D_{\not 2}} D_{\not \not ⿰}=0.5
$$

郎ち濃度 0.5 の時の分散光線を基準として $G$ を表はする筆者が提 唱したが後に Kusterにより次の如く改められた。Kは粒狀性

$$
K=100 \log _{10} \frac{D / 1}{D_{\#}} D_{\# 4}=0.5
$$

現在皆 Kuster の表現法を用ひてるる。而して粒狀性と $K^{-}$との期 保仕其後 Eggert, Kuster, Narath, Brandes, Lowry, Hausen,

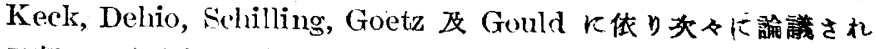
又新しい㜔驗數值が提出されたが現在の所次り詰論に達した。

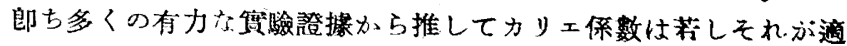
當な條件で用ひられた時には，粒狀性心指示法として極めて清足す べき結果の得られる一方然でする。而してカリェ保數は数子自身の 存在する大いさ (dimension) 及頻庭 (frequency) に低存する。郎与 
粒狀度（granularity）に依存する。從てカリェ保數が粒狀性（grainliness） と共に継化するものとすれ ば粒狀性 (grainliness) と粒狀 度 (granularity) とは密接な關係を有するものであると考入礼ばな らない。而して此方法はネガ材料の比較に限定し濃度一定の所で用 ふれば賽用性あることがはつきり示された，從て完全な意味に於て 粒狀性を測る尺度とはなり難い。要するに可なり狹い領域ではする がネガ材料的粒狀性を示すには十分に役立つ方法と稱することが出 來る。(Threadgold S. D, Photograplic Journal, 1939, Aug. 79, 524)

(庄野伸雄) (鉿 木)

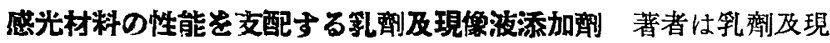
像液に添加劑を加一て感光乳劑(現像性を變一で，例一ば銀監の現 像後の色謂を blue black ならししたり或は brown black 調なら しめむりする物質を提出し又此色調の變化の原因につき考察を進 めてるる。郎ち blue black 調になる原因はハロゲン銀が現像され て集塊を形成するためである。依て現像の際に解膠作用，妨害作 用の强い物質を加一て現像すれば集塊は出來ずに brown black の 銀監の色調が得られる。印畫紙乳劑の貯藏中硬膜劑其他 $の$, ぬ brown 調のものが全く blue 調になるのも，保存中に其 反應が進 行したものと考へられる。乳劑製造の際の硬膜度, 或は水素イオン

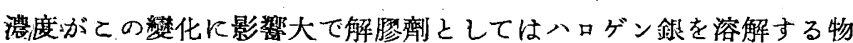
質が舉げられ，又アルカり性の時には blue 調に變化する傾向か抑 制される。從て現像は單なる化學反應でなく，物理現象を伴ふもの であるここは確筧である。

て.の他にカブリ防止劑の作用と減感作用との關保を述へ兩者は必 ずしも本行關保になく，減感作用は銀イオン,ハロゲンイオン.水素 イオンの各の濃度と關保があると云子 Luppo-Cramer の說を支持 してるる。添加劑としては Diäthyldithiokarbamat, Azidothiokohlensäure は熱乾燥處理の! 際の添加劑として用ひられ. Diphenyliodonium 化合物はカブ, y 除去及 brown black 調現像に效果 がある。其他 Felix Sager Gossler 會社の 商品名を冠する多くの 溫調現像添加劑妨害物質スポット妨害劇其他が舉げられてるる。 (A. Steigmann, Plot. Industrie, 1939, 37, 774, 800)

(庄野伸雄) (踰 木)

\section{6. 食品}

コーヒーとカフェイン コーヒーの害は純カフェインの藥學的研 究に依て不當に誇大されてるる。實際にコ一ヒ一を的さ場合はカ フェインの濃度低く量も少く，濃厚な純カフェイン溶液を用ひた動 物賽驗の場合々異る。又コーヒ一の人間に對する複哜な作用の研究 も少い。燒いたコーヒーの賽のカフェイン含量は普通 $1.0 \sim 1.3 \%$ で あるが其量はコーヒ一の品質と關係が無い。コーヒ一液中に出るカ フェインの量は種々の條件により異るが普通は約 $80 \%$ である。カ フェインは人體內で約 $98 \%$ 分解される。其變化は光分研觉されて ないが胝メチル基に次で酸化を受けると考い、られる。カフェインの 吸收はタンニンやクロロゲン酸に依て奶げられる。コーヒーに牛乳 を入れるとカフメインとクロロゲン酸と蛋白質とが結合して鄚溶性

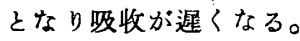

カフェインは疲勞恢復，鋲痛，强心，利尿等の效果があるが，不 眠, 矓量, 筋肉震顫, 心悸六進等の害もある。治療的服用量は人に より異るが約 $0.1 \mathrm{~g}$ である。コーヒーは濫用しなければ常用しても 健康者には害が無い。(W. Brandt, Chem. Ztg., 1939, 63, 525, $547)$ (梶塚 進)

牛釈の菜沸几よる損失 牛乳を加熱後 10 分で荎沸せしめ，直後 或は $2,4,5$ 分間煮沸後生じた皮膜とアルミニウム鎘に附着した残 渣とを集內各部分を分析した結果を平均せば表の如き損失がある。

惹沸乳の分析結果からの損失々皮及殘泚の分析結果からの損失々 の間飞罢隔のあるのは皮や殘渣の分離が困難なためで，蛋白質の場

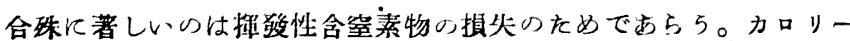

\begin{tabular}{|c|c|c|c|}
\hline & & $\begin{array}{l}\text { 原料の損 } \\
\text { 头 }(\%)\end{array}$ & $\begin{array}{l}\text { 皮之殘榅々 } \\
\text { の賣失(\%) }\end{array}$ \\
\hline & 固 形 物 & 13.29 & 10.0 \\
\hline 灰 & 分 & 5.75 & 4.22 \\
\hline & ルシウム & 13.73 & 8.24 \\
\hline & 燐 & 5.4 & - \\
\hline & 白 & 13.5 & 5.28 \\
\hline 脂 & 眆 & 23.5 & 30.27 \\
\hline 乳 & 糖 & 1.9 & . \\
\hline 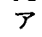 & ル ブミン & 74.13 & \\
\hline
\end{tabular}

の損失は $15.7 \%$ である。脂肪の損失最も多く，カルシウムと蛋白 質の損失も相當大きい。脂肪は主に皮一，蛋白質とカルシウムは大

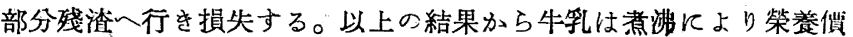
を約 10\% 損失すると言一る。(M. Andross, J. Suc. Chem. Ir d., $1939,58,252$ )

（梶塚 進）

ペクチンの研究 ペクチンはゼリーやジャムのみならず劣品, ア イスクリーム，チーズ，パン類等に用ひられるので其化學的研究の 興味が䁈した。ペクチンの性質は分子の鎮の長さと.メチル化の程度 により異る。分子の長さは grade (65\% のゼリー中いペクチン 1

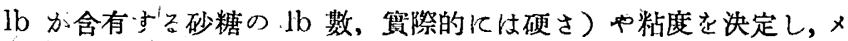

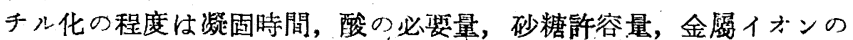
反應性等の性質を決定する。メチル化の程度は $N / 10 \mathrm{NaOH}$ て游 定した値, 師ち當量或け化合量 (equivalent or combining weight）火より簡單に知るととが出來る。ペクチンが脫メ゙チル基され ると化合量はそ机飞比例して減少する。商品のペクチンの化合量は 400 1550である。化合量の多いペクチンは凝固時間少く, 化合㝵 の減少汇從て㠜固時間は增加し 550 575 の間で極大に達し，更に 化合量が減少すると㠜固時間は再び念激に減少する。化合量が 800

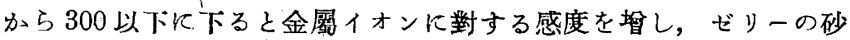
糖許容量を減少する。化合量の少いペクチンは或る $\mathrm{pH}$ の籁湋内 で異常な高糊度を示す。ペクチン溶液の粘度は䜿類や $\mathrm{pH}$ の影響 の無、場合は grade $飞$ 比例する。ゼリーを作る場合の所謂最適 $\mathrm{pH}$ なるものは猍い範圍內の條件に於てのみ存在するが一般的の意

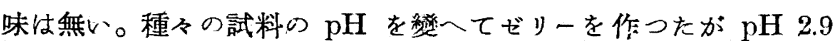
でも固まらないものがあり，酸性䋨街液では $\mathrm{pH} 3.1$ でも皆固まつ た。緩街液では酸の量を增し $\mathrm{pH}$ を所謂最適より上げ而も最强の ぜリーを作るととが出來る。(A. G. Olsen, R. F. Stuewer, E. R, Fehlberg and N. M. Beach, Ind. Eng. Chem., 1939, 31, 1015 （梶塚 進）

動物體內に於る脂肪酸の蕃皘及消費（第 II 報）斷食せる鼠飞玉

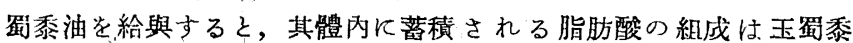
のそれと大體等しくなる。即ぢオンイン酸 $44.8 \%$ ，リノレイン酸 $32.3 \% \mathrm{C}_{16}$ の脂肪酸 $19 \%$ である。斷食中下消費される 各脂肪酸 の割合は大體動物體に於る割合々等しく, 體內に殘留する脂肪酸の 組成は斷食の前後殆ど不檤である。脂肪を蔗糖にて置换へカロリー 數を等しくした食飼を供與した場合は體內の脂肪酸的組成は變化し 能和酸が多くなる。此食饲を與へる前に鼠を斷食せしめると，此影 绵は大をく供與期間 9 日にして $\mathrm{C}_{16}$ の脂肪酸の大なる堆加を認め る。郎ちパルミヂン酸 $22.1 \%$, ークサデシノイン酸（パルミトオレ イン酸, ゾーマリン酸 $\left.\mathrm{C}_{16} \mathrm{H}_{30} \mathrm{O}_{2}\right) 12.1 \%$ となり，オレイン酸は 略等しく $46.7 \%$ にして,リノレイン酸は $13.2 \%$ に減少する。斷食 せ好鼠に於ては此影響少く，上記の食鸰を 23 日間供與した場合パ ルミチン酸 $16.7 \%$,へクサデシノイン酸 $6.6 \%$,オレイン酸 $50.8 \%)$, リノレイン酸 $20.2 \%$ である。毁ち體內に貯蓄された脂肪の置換作 用は變漫でむると洘へられる。

丙罚系油の脂肪酸を分析せる結果はパルミチン酸 $11.0 \%$ オレイ ン酸 $48.8 \%$,リ/レイン酸 $34.0 \%$, ミリスチン酸 $1.7 \%$, ステアリ ン酸 $2.9 \%$ にして，ての他新たにへクサデシノイン酸 $1.6 \%$ を發見 L.た。(H. E. Longenecker, J. Biol. Chem., 1939, 129, 13)

(横竹太郎) (堨野) 